\title{
MARIANA DE GOUVEA GUARDA
}

\section{POLÍTICAS PÚBLICAS E DIREITOS: UM ESTUDO DE CASO}

\author{
DISSERTAÇÃO DE MESTRADO
}

Orientador: Professor Doutor Jean Paul Cabral Veiga da Rocha

FACULDADE DE DIREITO DA UNIVERSIDADE DE SÃO PAULO

São Paulo

2014 
MARIANA DE GOUVEA GUARDA

\section{POLÍTICAS PÚBLICAS E DIREITOS: UM ESTUDO DE CASO}

Dissertação de Mestrado apresentada à Banca Examinadora da Faculdade de Direito da Universidade de São Paulo, como exigência parcial para a obtenção do título de Mestre em Direito, sob a orientação do Professor Doutor Jean Paul Cabral Veiga da Rocha

FACULDADE DE DIREITO DA UNIVERSIDADE DE SÃO PAULO

São Paulo

2014 
Nome: Guarda, Mariana de Gouvea

Título: Políticas Públicas e Direitos: Um Estudo de Caso

Dissertação de Mestrado apresentada à Banca Examinadora da Faculdade de Direito da Universidade de São Paulo, como exigência parcial para a obtenção do título de Mestre em Direito, sob a orientação do Professor Doutor Jean Paul Cabral Veiga da Rocha 


\section{AGRADECIMENTOS}

Gostaria de iniciar agradecendo meu orientador Prof. Jean Paul, por toda a ajuda nos últimos 3 anos, mas principalmente nessa fase final de consolidação e aprimoramento da dissertação.

Não poderia deixar de agradecer aos bolsistas e colaboradores do Programa de Educação Tutorial da Faculdade de Direito da Universidade de São Paulo, assim como ao Prof. Faria, tutor do Programa. Foram muitos anos de aprendizado e ricas experiências acadêmicas e pessoais, que mantêm seu reflexo até os dias de hoje.

Ao Prof. Faria e ao Prof. Coutinho, pelas valiosas dicas durante a Banca de Qualificação.

À minha família, pela paciência, tolerância e auxílio, durante todos esses anos de formação acadêmica e profissional. À minha mãe, Aparecida, cujo conhecimento e capacidade são uma inspiração para mim. A meu pai, Roberto, pelas várias xícaras de café pela manhã. À minha irmã, Juliana, pelos momentos de descontração e leveza mesmo nas épocas de maiores tensões.

Aos meus colegas da Defensoria Pública do Estado de São Paulo, Ligia Guidi, Eduardo Kotake, Guilherme Bedin, Mariana Carrara, William Braga, Paulo de Divitiis, pelas longas conversas, dicas e leituras atentas.

Ao Dr. Carlos Weis, pela possibilidade de realizar os atendimentos à população em situação de rua, no Núcleo de Cidadania e Direitos Humanos da Defensoria Pública.

À Rafaela Barbosa, Bruno L'Astorina, Mariana Valente, Luciana Reis e Yuri Luz, pelas inúmeras conversas e palavras de conforto.

À Regina Brasil, Eliana Victoriano, José Geraldo, Taísa Endrigue e Floriano Pesaro, pelo auxílio nas pesquisas acadêmicas e reconstrução de momentos históricos.

A todos aqueles envolvidos com a questão da rua, expresso meu agradecimento nas pessoas de Alderón Costa, Padre Julio Lancellotti e Anderson Miranda, que me auxiliaram desde o início de meu envolvimento e estudos sobre o tema. 


\section{$\underline{\text { Resumo }}$}

O presente projeto buscará discutir as políticas públicas voltadas à população em situação de rua na cidade de São Paulo, tratando especificamente de um centro de serviços conhecido como Complexo Boracea, estabelecido em 2003 pela prefeita Marta Suplicy.

O trabalho parte do pressuposto de que em meados da década de 80, a população de rua surgiu como tema a ser debatido e politizado, e tornou-se uma questão pública a ser resolvida por meio do Estado e de políticas públicas. Na cidade de São Paulo, além do marco jurídico estabelecido pela Lei de Atenção à População de Rua (lei municipal 12.316, de 16 de abril de 1997) e sua posterior regulamentação (Decreto 40.232, de 2 de Janeiro de 2001), houve em âmbito nacional a edição da Política Nacional para Inclusão Social da População de Rua por meio do Decreto 7.053, de 23 de dezembro de 2009, incorporado no ano de 2013 à política municipal da capital paulista.

Tendo em vista a população em situação de rua na cidade de São Paulo, esse trabalho buscará analisar, como objetivo geral, a atual configuração dos serviços voltados especificamente para a população em situação de rua - como Centros de Acolhida ("albergues"), Centros de Convivência e Tendas, dentre outros - e, como objetivo específico, o Complexo Boracea.

O serviço prestado pelos albergues sempre se mostrou central dentro da estrutura dos serviços voltados à população de rua. Dessa forma, a descrição de um dos equipamentos especificamente criados para atender a população em situação de rua colabora para a análise das políticas públicas municipais para essa população, sendo possível se tecer algumas conclusões sobre a atual rede de serviços públicos voltados às pessoas em situação de rua na cidade de São Paulo.

Palavras-chave: população em situação de rua; política social; assistência social; albergues; gestão pública. 


\section{$\underline{\text { Abstract }}$}

This dissertation analyses the social policies aimed at homeless people in the city of São Paulo, focusing on one particular shelter known as Boracea Complex, stablished in 2003 by the mayor Marta Suplicy.

This work assumes that in the 80 's, homeless people emerged as a theme to be debated in the public arena, and that demanded the attention of the State and the formulation of specific social policies. In the city of São Paulo, there are two legal statues directed to the homeless people: Municipal Law n. 12.316 of 1997 and Municipal Decree n. 40.232 of 2001. Nationally, the decree n. 7053 of 2009 regulates the National Social Policy for the inclusion of homeless people, incorporated in the city of São Paulo only in 2013.

The evolution and configuration of the services towards the homeless people ill be analysed, specifically shelters and community centers. Nevertheless, the main focus will be the description of the services stablished in the Boracea Complex, since its opening.

The shelters and community centers have always been a central aspect in the services towards homeless people. That is way the description of this particular Complex is helpful in the analysis of the social policies towards this group of people, making it possible to draw some conclusions about the current programms and services for this group of people.

Keywords: homeless people; social policy; social assistence; shelters; public administration. 


\section{LISTA DE ABREVIATURAS E SIGLAS}

AEB - Associação Evangélica Beneficente

AMA - Assistência Médica Ambulatorial

APOIO - Associação de Auxílio Mútuo da Região Leste

BPC - Benefício de Prestação Continuada

CAE - Centro de Acolhida Especial

CAP - Caixas de Aposentadoria e Pensão

CAPE - Central de Atendimento Permanente e de Emergência

CETREM - Centro de Triagem e Encaminhamento de São Paulo

CDCM - Centro de Documentação e Comunicação dos Marginalizados

CECOAS - Centro do Conhecimento da Assistência Social

CEEP - Centro de Educação Estudos e Pesquisas

CEPAL - Comissão Econômica para a América Latina e Caribe

CERU - Centro De Estudos Rurais e Urbanos

CNAS - Conselho Nacional da Assistência Social

CRAS - Centro de Referência da Assistência Social

CREAS - Centro de Referência Especializado de Assistência Social

CROPH - Coordenação Regional das Obras de Proteção Humana

ESPASO - Espaço Público do Aprender Social

FIPE - Fundação Instituto de Pesquisas Econômicas

IAP - Institutos de Aposentadorias e Pensões

LBA - Legião Brasileira da Assistência

LOAS - Lei Orgânica da Assistência Social

MDS - Ministério do Desenvolvimento Social e Combate à Fome

MNCR - Movimento Nacional de Catadores de Materiais Recicláveis

MNPR - Movimento Nacional da População de Rua

OAF - Organização do Auxílio Fraterno

ONU - Organização das Nações Unidas

PMSP - Prefeitura Municipal de São Paulo

PNAS - Política Nacional de Assistência Social

SACECOP - Serviço de Apoio Sócio Educativo de capacitação e orientação profissional

SAS - Secretaria de Assistência Social

SMADS - Secretaria Municipal da Assistência e Desenvolvimento Social

SUAS - Sistema Único da Assistência Social

SISRUA - Sistema de Informação da Situação de Rua

UBS - Unidade Básica de Saúde 


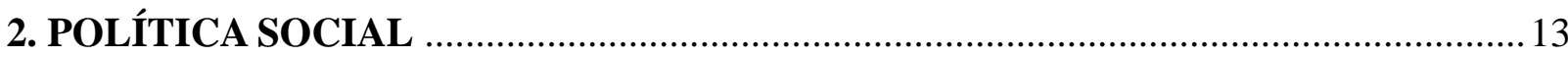

2.1. Política social: conceitos e marcos............................................................... 13

2.2. Breves delineamentos sobre a política social na América Latina ................. 17

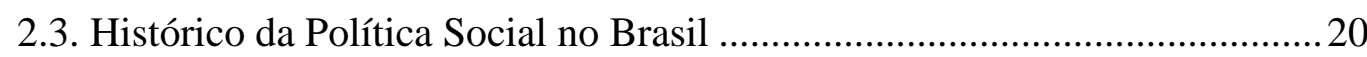

2.4. Políticas Públicas na Assistência Social ...................................................... 25

2.4.1. Assistência Social: funções e atribuições ................................................25

2.4.2. Marco Constitucional e regulamentação legal da Assistência Social... 33

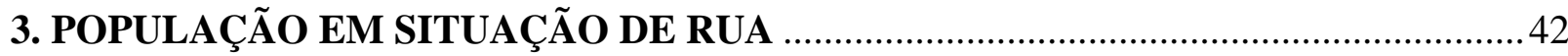

3.1. A População em Situação de Rua como Questão Social ............................... 42

3.2. População Em Situação De Rua: Principais Características ........................ 51

3.3. Políticas públicas para a população de rua em São Paulo .............................. 60

3.4. Relação dos Serviços Previstos e Tipificados .................................................69

3.5. Albergues ou Centros de Acolhida ........................................................... 78

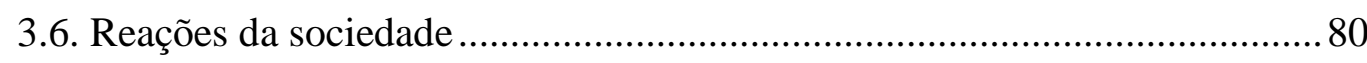



4.1. O programa “Acolher: Reconstruindo Vidas" ............................................ 87

4.2. A inserção do Complexo Boracea na Rede de Atendimento ......................... 90

4.3. O projeto inicial desenvolvido ............................................................... 92

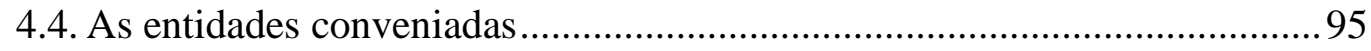

4.4.1. Fase inicial: os convênios celebrados entre 2003-2006 ….................. 95

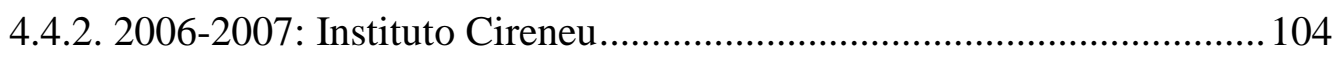

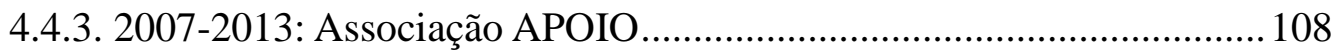

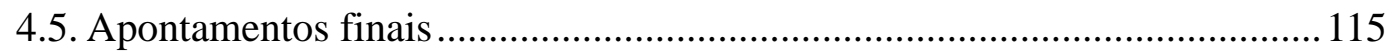

4.5.1. Variedade de associações e gestão.................................................... 115

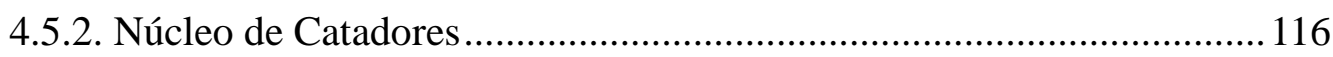

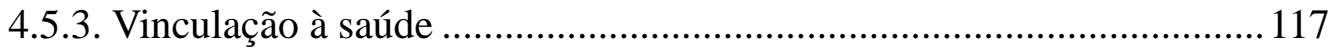

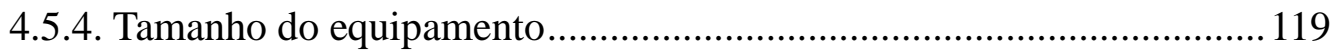

4.5.5. Cursos profissionalizantes ............................................................ 121

4.5.6. "Higienismo" e repressão ............................................................... 122

5. CONCLUSÕES

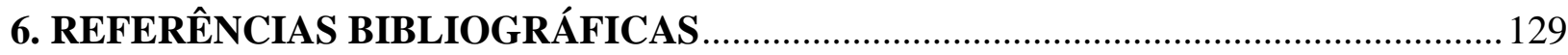




\section{INTRODUÇÃO}

O cenário urbano tem suas marcas, principalmente em grandes capitais como a cidade de São Paulo; nas ruas, há também pessoas, que se utilizavam do espaço público urbano para desenvolver suas atividades cotidianas e mesmo privadas. Vivem na rua e da rua, e na capital paulista já constituem quase 15 mil pessoas.

Em que pese a presença diária de pessoas vivendo na rua, o cotidiano dessa parte da população é pouco conhecido e explorado, e suas vidas se mantêm na invisibilidade. Pouco se sabe, no senso comum, quem são essas pessoas, da onde veem, e porquê fatalidade da vida se encontram em tal situação, e em boa parte do tempo, sequer se há interesse. Quando surgem como tema, aparecem como alvo de opiniões ambíguas: de um lado, há quem busque mitigar a situação de penúria na qual tais indivíduos se encontram, procurando agir de forma caridosa, oferecendo alimentos e roupas. Contudo, há aqueles que, por intermédio de diversas iniciativas, tentam manter tais pessoas em situações de exclusão cada vez maior, impedindo sua livre circulação e até mesmo a utilização de espaços públicos em suas práticas cotidianas. ${ }^{1}$

Algo semelhante pode ser dito em relação à elaboração legislativa. Ao mesmo tempo em que há projetos de lei que buscam garantir os direitos dessa população e concretizar seu status de cidadãos, há iniciativas de lei que se mostram claramente preconceituosas e violadoras de direitos. O mesmo ocorre no veículos midiáticos, que oscilam em veicular notícias em defesa dos direitos dessas pessoas, mas em outros momentos disseminam ideias estigmatizantes e preconceituosas. ${ }^{2}$

No início do ano de 2012, a temática envolvendo a população em situação de rua ganhou grande repercussão como decorrência das operações realizadas na área conhecida como "Cracolândia", localizada no Centro da Cidade de São Paulo. A operação voltava-se primordialmente para a retirada dos usuários de crack da região e para posterior encaminhamento a tratamento médico. Contudo, foram ferrenhas as críticas de organizações de direitos humanos em face da abordagem policial utilizada, das violações

1 São comuns os exemplos da conhecida "arquitetura anti-mendigo", com cercamento de praças e marquises, construção de bancos de cimento que impeçam a sua utilização para dormir e rampas embaixo de pontes, com claro objetivo de impedir que tais pessoas se utilizem desses espaços públicos.

2 Além do processo legislativo, os veículos midiáticos também apresentam discursos que vão nas duas direções. Para uma análise mais detalhada, ver GIORGETTI, Camila. Poder e contrapoder: imprensa e morador de rua em São Paulo e Paris. São Paulo: Fapesp/EDUC, 2007; GIORGETTI, Camila. Moradores de rua: uma questão social? São Paulo: Fapesp, Educ, 2010. 
de direitos humanos dos usuários de droga, devido ao cerceamento de suas liberdades de locomoção. A operação na Cracolândia fez ressurgir também um tema latente no que se refere ao combate ao uso de drogas: a internação compulsória das pessoas consideradas "viciadas", gerando, como consequência, o questionamento sobre as alternativas de políticas públicas para essas pessoas.

A População em Situação de Rua se mostra como a expressão radical da questão social. No Brasil, o preconceito existente e a tendência à naturalização do fenômeno são reforçados e se fazem acompanhar da quase inexistência de dados e informações científicas sobre o assunto, além das poucas políticas públicas efetivas para enfrentar o problema. ${ }^{3}$

Desde muito tempo, moradores de rua vem sendo ajudados por meio do auxílio privado, seja por meio da igreja ou mesmo pela ajuda comunitária. Esse auxílio, voluntário e contingencial, sempre ocorreu por meio de oferecimento de comida, roupas e abrigo, ou mesmo ajuda espiritual. Só recentemente, a partir do final da década de 80 , houve uma alteração em tal paradigma de auxílio, sendo compreendida a necessidade de formulação de uma política pública específica para esses indivíduos, estruturando-se, por consequência, uma rede de serviços públicos - paralelo ao auxílio privado, que continuou a ser prestado - de forma a garantir direitos e buscar a satisfação de suas necessidades básicas.

Na cidade de São Paulo, a Lei de Atenção à População em Situação de Rua estabelece como obrigação do poder público municipal - por intermédio da Secretaria de Assistência Social - a prestação de atendimento a essas pessoas. Porém, há uma particularidade: os serviços e programas criados poderão ser prestados diretamente pelo poder público ou por contratos e convênios com entidades sem fins lucrativos. Em São Paulo, a grande maioria dos serviços assistenciais decorrem de convênios celebrados entre a Prefeitura e associações civis.

No início da formulação de políticas públicas para os moradores de rua, os primeiros serviços criados foram os Centros de Convivência e os Albergues, proporcionando possibilidades de convivência, garantindo-se também a acolhida no período noturno, alimentação e banho. Até hoje, os albergues (ou centros de acolhida) mantêm-se como uma das principais formas de serviços voltados para a população de rua.

\footnotetext{
3 Política Nacional para Inclusão da População de Rua. Brasília/DF. 2008. p. 4.
} 
Dentre todos os serviços previstos, são diversos os centros de acolhida existentes, que às vezes atuam em face à população de rua com programas que não se restringem à pernoite e alimentação, podendo também ofertar cursos e atividades de convivência. Nesse contexto, o Complexo Boracea, localizado no centro de São Paulo, foi elencado como objeto específico desta pesquisa. Primeiramente, o local se mostra privilegiado tanto em termos da grande variedade de serviços quanto em número de usuários atendidos. O espaço também recebe considerável investimento mensal por parte da Prefeitura de São Paulo. Ademais, desde sua abertura em 2003, foi alvo de opiniões ambíguas: ao mesmo tempo que fora premiado como iniciativa de grande sucesso em termos de atendimento à População em Situação de Rua, pois promovia atividades voltadas à reinserção social, foi objeto também de diversas críticas, sendo considerado grande e caro.

Nesse sentido, e pelos motivos acima mencionados, o Complexo Boracea apresenta características interessantes para a realização de um estudo de caso sobre políticas públicas voltadas à população de rua na cidade de São Paulo.

Para a análise do Complexo Boracea, partiu-se da revisão bibliográfica, com foco em situar a questão das políticas sociais no Brasil, voltando-se de forma específica para as políticas criadas no âmbito da assistência social. No mais, procedeu-se à análise de obras voltadas especificamente para o tema população em situação de rua, além de notícias de jornal.

Ademais, buscou-se analisar leis e documentos públicos, principalmente aqueles produzidos em âmbito municipal, tendo em vista que os serviços voltados à população em situação de rua são de competência primordialmente dos municípios. Dessa forma, o objeto de pesquisa foi formado a partir do cruzamento e interligações entre discursos e textos que se revolvem ao redor do objeto de pesquisa ${ }^{4}$.

Assim, o que se pretende por meio dessa dissertação é se proceder à descrição de um equipamento público voltado especificamente à população em situação de rua, analisando a evolução dos serviços prestados e dos convênios celebrados entre poder público e entidades sem fins lucrativos. Por meio da descrição do centro de acolhida acima indicado, se terá por intenção analisar, na medida do possível, a evolução, dentro da cidade de São Paulo, da política pública voltada a esta população, notando-se especificamente, a alteração e o aumento dos serviços fornecidos.

4 DESLAURIERS, Jean-Pierre; KÉRISIT, Michèle. O delineamento da pesquisa qualitativa. p. 135. 
Dessa forma, a partir da descrição deste centro de serviços, será possível se tecer algumas considerações sobre a atual rede de serviços públicos voltados à população em situação de rua na cidade de São Paulo.

Por fim, buscar-se-á também analisar o papel do Direito dentro de uma política pública recém instituída, ponderando se o arcabouço jurídico criado foi capaz de auxiliar na garantia de direitos, no desenvolvimento de programas e na prestação de serviços. 


\section{POLÍTICAS SOCIAIS}

\subsection{Política social: conceitos e marcos}

Para se discutir o tema de políticas públicas para a população em situação de rua, primeiramente é necessário se entender como surgiu a noção atual de política social, assim como entender o papel do Estado nesse contexto.

Primeiramente, é necessário se notar que a emergência da pobreza como questão social data do início da era industrial, momento no qual se deu a quebra das relações tradicionais decorrentes do feudalismo. Nesse período histórico, surgiu o reconhecimento de que alguma forma de proteção social era necessária a fim de regular a questão do trabalho e atenuar as consequências das situações de pobreza extrema, dando origem a um fenômeno historicamente datado conhecido como "Questão Social”. Esse fenômeno, surgido na Europa do século XIX como decorrência das transformações da revolução industrial, pode ser entendido como uma tomada de consciência de novos problemas sociais surgidos em decorrência da alteração das condições do trabalho urbano e das demandas sociais daí resultantes. ${ }^{5}$

Nota-se, portanto, que antes dessa tomada de consciência, a pobreza não era considerada um problema ou um elemento disfuncional dentro da sociedade a ponto de demandar atenção e soluções. Em realidade, por muito tempo, entendeu-se que a presença de um certo número de pessoas pobres era desejável, pois era condição para que tais pessoas trabalhassem e trouxessem a riqueza da nação. Dessa forma, as preocupações com a população não envolviam a redução da pobreza, mas sim somente a contabilização de indivíduos com aptidão para incrementar a produção e riqueza nacionais. Ademais, a pobreza era vista como uma oportunidade política, na qual alguns homens virtuosos teriam a possibilidade de disciplinar os homens pobres - e consequentemente, homens preguiçosos, e com vícios -, decorrendo daí as relações comuns entre homens na época do feudalismo, marcada pela proteção por dependência.

Nesse contexto, a classe superior seria responsável pelo destino das populações pobres, regulando e comandando suas vidas, já que os pobres eram vistos como crianças, para os quais as classes mais abastadas forneceriam uma moral e uma ética, além de lhes

\footnotetext{
FLEURY, Sônia. O Estado sem cidadãos. Seguridade Social na América Latina. Editora Fiocruz: Rio de
} Janeiro, 1994. p. 61. 
proporcionar proteção social:

"Estas relações tradicionais de autoridade estavam fundadas na crença da desigualdade natural entre homens e na reciprocidade de expectativas radicadas nas diferentes funções que cada um deveria cumprir na sociedade."

O Estado não era chamado a intervir nessas relações, pois a questão da pobreza não havia sido elevada à categoria de problema social. Ademais, a proteção social necessária à população empobrecida já era garantida por meio das relações paternalistas estabelecidas entre pobres e ricos. ${ }^{6}$

A certa altura, quando surgiram os embriões do pensamento liberal-burguês, com a consequente defesa da igualdade formal, rompe-se com o paradigma predominante de relações de trocas que tinha por base a desigualdade entre os homens, e que gerava, por consequência, as relações paternalistas de proteção. Contudo, o rompimento dessas relações tradicionais de proteção social - que se situava na esfera civil até o momento não teve por reflexo a imediata atuação estatal; houve um momento de transição, no qual a população empobrecida permaneceu desprovida de qualquer proteção social. ${ }^{7}$

Aos poucos, com o crescimento das críticas e das pressões contra o pauperismo em massa, as causas da pobreza foram sendo desmistificadas, e em alguns países iniciou-se a introdução de medidas pontuais de proteção social. ${ }^{8}$ A certa altura notou-se que somente a caridade e poucas investidas tímidas de regulação social eram insuficientes, e como estratégia generalizada, entendeu-se que para o enfrentamento da pobreza estrutural não bastava iniciativas isoladas dentro da sociedade. Era necessária a intervenção do Estado, introduzindo alterações e dando origem ao que seria a Seguridade Social no Estado Contemporâneo. ${ }^{9}$

Na História Mundial, houve diversos padrões de incorporação estatal de demandas sociais, o que levou a diversas formas de relação entre Estado e Sociedade ${ }^{10}$. Ou seja:

FLEURY, Sônia. O Estado sem cidadãos. Seguridade Social na América Latina. (...) pp. 61-62.

FLEURY, Sônia. O Estado sem cidadãos. Seguridade Social na América Latina. (...) p. 62.

PEREIRA, Potyara A.P., Política Social: Temas \& questões. São Paulo: Editora Cortez, 2011. p. 81.

CARVALHO, Maria do Carmo Brant. A Seguridade na travessia do Estado assistencial brasileiro. p. 144.

Não se pretendeu nesse trabalho discutir as particularidades do que fora denominado como Welfare State, e seu momento específico de inserção na história da política social no pós-segunda guerra mundial. Alguns autores entendem que o Welfare State de pós-45 apresentou-se o ápice de uma lutada por proteção social em países industrializados travada durante um século (ESPING-ANDERSEN, Gosta. Welfare States in transition: national adaptations in global economies. UNRISD. 1996. Prefácio). Apontam para a diferenciação entre a política social em geral e o particular momento ocorrido a partir de 1945. Para um apanhado geral sobre a inserção do Welfare State FLEURY, Sônia. O Estado sem cidadãos. Seguridade Social na América Latina. Editora Fiocruz: Rio de Janeiro, 1994. pp. 101-127 e PEREIRA, Potyara A.P. Política Social: temas \& questões. pp. 23-58. 
processos de industrialização diversos em contextos de legados históricos diferentes, com relações político-econômicas, culturais e ideológicas distintas deram origem a uma série de modelos de relação Estado-Sociedade, o que por sua vez engendrou arranjos diversos de políticas sociais. ${ }^{11}$ Ademais, os processos de consolidação e formação dos mecanismos de proteção social em cada sociedade constituem sistemas de proteção social com maior ou menor abrangência, e se caracterizam por sua dinamicidade, estando na maior parte do tempo em construção ou reforma. ${ }^{12}$

Como consequência desta variedade de contextos, assim como a constante alteração dos mecanismos internos de proteção social em cada país, compreende-se a complexidade - e, quiçá, até a impossibilidade - na elaboração de um conceito único do que seria a política social, tendo em vista a grande faceta de subjetividade em torno do tema. Tal constatação não torna a discussão teórica irrelevante, mas só demonstra que a ausência de preocupação em atingir um consenso conceitual sobre o que seria uma política pública aponta justamente para o lado prático e concreto das políticas, já que grande parte das reflexões sobre o assunto varia conjunturalmente e é reflexo das condições e dos problemas sociais vigente em cada país. ${ }^{13}$

Nesse contexto de grande variabilidade e diferenças entre contextos nacionais, de forma a buscar um conceito minimante conciliatório, pode-se entender a política social como "composta por um conjunto de programas e ações do Estado, com o objetivo de atender às necessidades e os direitos sociais que afetam vários dos componentes das condições básicas de vida da população, inclusive aqueles que dizem respeito à pobreza e à desigualdade,${ }^{14}$

Dessa forma, a política social pode ser entendida como sendo uma relação social que se estabelece entre Estado e classes sociais, e que tem por foco a reprodução das classes mais empobrecidas, buscando a construção de relações de cidadania, reforçando a vinculação entre Estado e cidadão com o fim de reconhecimento de direitos positivos. ${ }^{15} \mathrm{~A}$ cidadania, neste contexto, pode ser entendida como uma espécie de igualdade humana básica, associada a uma ideia de participação integral dentro da comunidade, implicando

11 FLEURY, Sônia. O Estado sem cidadãos. Seguridade Social na América Latina (...) p. 59.

12 CASTRO, Jorge de Castro; RIBEIRO, José Aparecido; CAMPOS, André Gambier; MATIJASCIC, Milko. A CF/88 e as políticas sociais brasileiras. (...) p.57.

13 CASTRO, Jorge de Castro; RIBEIRO, José Aparecido; CAMPOS, André Gambier; MATIJASCIC, Milko. A CF/88 e as políticas sociais brasileiras. (...) p. 56.

14 CASTRO, Jorge de Castro; RIBEIRO, José Aparecido; CAMPOS, André Gambier; MATIJASCIC, Milko. A CF/88 e as políticas sociais brasileiras. (...) p. 58.

15 FLEURY, Sônia. O Estado sem cidadãos. Seguridade Social na América Latina. (...) p. 59. 
no estabelecimento entre direitos e deveres entre Estado e seus cidadãos. ${ }^{16}$ Ao mesmo tempo, ressalta-se o fato de que a construção da cidadania não ocorre por meio de um Estado acabado, que forma os cidadãos por meio de sua própria lógica, mas sim significa compreender que a formação da cidadania se dá conjuntamente à formação do próprio Estado. $^{17}$

A política social, portanto, se apresenta como o espaço de concretização de interesses da população empobrecida, embora em termos limitados, tendo em vista se tratar de uma relação em que figuram interesses conflitantes entre sociedade de Estado. ${ }^{18}$

Em sua visão histórica, a política social sempre alternou abordagens voltadas centralmente para provisões universais com abordagens focalizadas em certos setores da sociedade. Enquanto na política universalista toda a população se vê beneficiária de serviços sociais, o focalismo elege alguma característica ou aspecto de maneira a escolher o grupo que mereceria maior atenção social. De forma geral, a política social de um país dificilmente recai só no focalismo ou no universalismo: em geral é híbrida, caracterizandose por aspectos voltados mais ao focalismo ou ao universalismo, mas possuindo características dessas duas formas de abordagem. ${ }^{19}$

Quanto aos objetivos principais da política social, em linhas gerais, pode-se dizer que esses são dois: realizar a promoção social e buscar a solidariedade social. Por promoção social entende-se a busca pela geração de oportunidades e de resultados para indivíduos e/ou grupos sociais. Já a busca pela solidariedade social revela-se através da garantia de segurança ao indivíduo em determinadas situações de dependência ou vulnerabilidade, como em casos de incapacidade de ganhar a vida por conta própria em decorrência de fatores que independem da vontade individual, vulnerabilidade devido ao ciclo vital (crianças e idosos) ou em casos de situações de risco, como no caso de acidentes

16 MARSHALL, Thomas Humphrey. Cidadania, classe social e status. Zahar Editores: Rio de Janeiro. 1967. p. 62.

17 FLEURY, Sônia. O Estado sem cidadãos. Seguridade Social na América Latina. (...) p. 60.

18 SPOSATI, Aldaíza de Oliveira et al. A assistência na trajetória das políticas sociais brasileiras: uma questão em análise. 11 a edição. São Paulo: Cortez. 2011. p. 24.

19 MKANDAWIRE explica que durante as décadas de 60 e 70, a tendência dentro das políticas sociais era se voltar para políticas universalistas. Contudo, a partir da década de 80, tal quadro se alterou, sendo que tanto em países desenvolvidos como em desenvolvimento foram favorecidas políticas voltadas para a focalização. (MKANDAWIRE, Thandika. Targeting and Universalism in poverty reduction. Social Policy and Development Programme Paper Number 23. December 2005. p. 1). Contudo, em que pese a pecha que recai sobre a focalização dentro da política social, por se tratar de uma abordagem entendida como conservadora, há quem diga que a seletividade na distribuição de benefícios sociais pode se apresentar através de uma perspectiva progressista (DRAIBE, Sônia Maria. As políticas de combate à pobreza na América Latina. In: São Paulo em Perspectiva. Volume 4 (2). pp. 18/24. 1990. p. 23). 
(invalidez por acidente). ${ }^{20}$

Observa-se, portanto, que, atualmente, o Estado tem o dever de zelar pela proteção social dos cidadãos, através de programas e ações voltados ao atendimento das necessidades de grupos vulneráveis.

\subsection{Breves delineamentos sobre a política social na América Latina}

Como já mencionado acima, a política social de cada país irá variar de acordo com as relações político-econômicas presentes nos variados contextos nacionais e regionais.

Nesse sentido, é necessário se ressaltar que a construção da política social na América Latina deu-se de forma diversa daquela estruturada na Europa Central, em especial no que toca ao momento posterior à Segunda Guerra Mundial. Enquanto nos países europeus, foi articulada uma proposta unificada de respostas aos problemas sociais, na América Latina houve respostas mais fragmentadas e setoriais. ${ }^{21}$

De maneira relativamente uniforme, as primeiras iniciativas voltadas à segurança social nos países latino-americanos deram-se nas carreiras militares e quanto a funcionários civis e do judiciário ${ }^{22}$. Contudo, em que pese essas primeiras iniciativas, pode-se dizer que se iniciou um modelo de proteção social na América Latina a partir do processo de crise do modelo agroexportador, e do crescimento de camadas médias urbanas e da população urbano-operária, sendo forte a presença de ideologias socialistas e anarquistas. $^{23}$

Efetivamente, após as carreiras civis e militares, expandiram-se medidas para os setores estratégicos e mais organizados das carreiras da classe média e classe operária, como jornalistas, bancários, professores e trabalhadores ferroviários e portuários; ao fim, houve extensão dos benefícios para setores mais amplos da classe operária, como mineiros, servidores público e trabalhadores da indústria têxtil. Autônomos e trabalhadores informais permaneceram, em sua maioria, excluídos do sistema de segurança social. A proteção

${ }^{20}$ CASTRO, Jorge Abrahão de; RIBEIRO, José Aparecido; CAMPOS, André Gambier; MATIJASCIC, Milko. A CF/88 e as políticas sociais brasileiras. (...) p. 59.

21 SPOSATI, Aldaíza. Tendências latino-americanas da política social pública do século 21. In: Revista Katálisis. Florianópolis. Volume 14, n. 1, p. 106.

22 FLEURY, Sônia. O Estado sem cidadãos. Seguridade Social na América Latina. (...) p. 176.

23 A classe operária urbana e a classe média se mostravam mais organizadas que os grupos formados por desempregados, autônomos ou trabalhadores rurais e exigiam, de forma mais enfática, proteção social contra acidentes de trabalho, doenças e velhice. 
social para trabalhadores rurais foi tardia, e em alguns países nem chegou a se iniciar. ${ }^{24}$

Naturalmente, os países da região apresentaram abordagens diversas sobre como lidar com os problemas sociais de seus cidadãos, e em momentos diferentes. Os modelos específicos de políticas sociais formuladas e o momento em que ocorreram deveram-se à história política de cada país, que por sua vez refletiu a interação da construção do estado e a estrutura de classes e as alianças econômicas. ${ }^{25}$

Enquanto alguns países ${ }^{26}$, dentre eles, o Brasil, desenvolveram, desde a década de 20, alternativas sociais em decorrência da industrialização e em face das demandas sociais apresentadas pelos trabalhadores urbanos, outros países tiveram iniciativas mais tardias. $\mathrm{Na}$ década de 40, países como México e Venezuela ${ }^{27}$, desenvolveram medidas incidentais, ao mesmo tempo em que na Europa a política social se orientava pelos princípios do Relatório Beveridge. ${ }^{28}$ Ao final da década de 50 e início da década de 60 , um grupo mais tardio de países latino-americanos ${ }^{29}$ apresentaram algumas medidas sociais, em que pese de forma residual e excludente. ${ }^{30}$

Ao analisar quatro países na região - Brasil, Argentina, Chile e Costa Rica - Huber chegou a algumas conclusões. No Brasil e Argentina, as primeiras iniciativas legais ocorreram por meio de elites conservadoras em resposta a demandas trabalhistas e os regimes corporativistas utilizaram-se de tal estrutura de forma a controlar o movimento sindical. Já em países como Chile e Costa Rica, os modelos de política social se formaram sob regimes democráticos, com viés mais conservador no Chile e mais voltado à socialdemocracia na Costa Rica. Quanto à estruturação de um sistema de proteção, o modelo estabelecido na Costa Rica se desenvolveu de forma unificada e solidária, buscando, de

24 HUBER, Evelyn. Options for social policy in Latin America: Neoliberal versus democratic models. p.147.

25 HUBER, Evelyn. Options for social policy in Latin America: Neoliberal versus democratic models. pp.144-147.

26 Brasil, Chile, Uruguai, Argentina e Cuba.

27 Além do México e Venezuela, Costa Rica, Equador, Peru, Panamá, Paraguai, Colômbia e Venezuela também encontram-se nesse grupo.

28 O chamado Relatório ou Informe Beveridge sobre o Seguro Social e Serviços Afins (Reporto on Social Insurance and Allied Services) foi um documento elaborado sob coordenação de William Beveridge, publicado em 1942. Esse relatório propunha uma revisão no sistema de proteção social britânico da época. Implementado pelo governo trabalhista de Clemente Atlle, o novo sistema proposto pelo Relatório Beveridge inovou, pois era nacional e unificado, e trazia ao mesmo tempo dois eixos, um distributivo e um contributivo. Ademais, aboliu os testes de meio no âmbito da assistência social. Após a Segunda Guerra Mundial, foi responsável por significativos avanços em termos de política social. In: PEREIRA, Potyara A.P. Política Social: temas \& questões. pp. 93-94. República Dominicana, El Salvador, Guatemala, Nicarágua, Haiti e Honduras.

30 MESA-LAGO, Carmelo. Models of Development, Social Policy and Reform in Latin America. pp. 186187. 
forma geral, os princípios da universalização da cobertura - no que toca à saúde padronização de benefícios, unificação da administração e em alguns aspectos solidariedade no financiamento. Já no Brasil, Argentina ${ }^{31}$ e Chile, os modelos de política social se desenvolveram de forma fragmentada e desigual, reforçando a distinção entre classes e colocando a ligação ao mercado de trabalho como elemento central, não havendo proteção social adequada para aqueles que se encontram fora do mercado formal. Os regimes militares da década de 60 contribuíram em alguma medida para a unificação dos sistemas, mas a desigualdade dos modelos de proteção social se mantiveram. ${ }^{32}$

A década de 80 teve um forte impacto na política social nos países latinoamericanos. Notou-se um aumento no nível de pobreza, acompanhado da redução do gasto social e deterioração dos serviços públicos. A crise econômica deu espaço para a atuação de instituições financeiras internacionais, em especial o Fundo Monetário Internacional FMI - bancos privados e países credores, cuja visão ideológica dominante era a neoliberal. Em 1980-1981, o Chile foi pioneiro no que toca às reformas estruturais radicais do modelo de pensões e saúde, voltando-se para o paradigma liberal e focando-se na privatização. Devido às crises da década de 80 e do fato de os países latino americanos não apreciarem o modelo político - autoritário - Chileno, tais reformas ocorridas em alguns países não tiveram impacto até a década de 90, quando, tendo em vista a inflação e o apoio de grupos nacionais, as medidas neoliberais tornou-se mais popular pelos países da região. ${ }^{33}$

Dessa forma, em face do novo contexto inaugurado na década de 80, nota-se que a reação dos países da região tendeu a ser multifacetada. Alguns optaram por soluções neoliberais, voltadas para a privatização, como o Chile, enquanto outros optaram por alternativas voltadas à universalização e consolidação de modelos públicos, como a Costa Rica. Países como Argentina e Brasil, por exemplo, mantiveram-se em posições intermediárias, sendo que o primeiro adotou medidas mais voltadas ao modelo privado,

31 SPOSATI indica que na Argentina e Uruguai, em momento anterior às ditaduras, foi possível o crescimento da proteção social, tendo em vista que essas sociedades se aproximaram do pleno emprego. Contudo, o foco sempre fora a condição do trabalho formal, e não a cidadania, o que distancia esses sistemas de um política social efetivadora de garantias a todos cidadãos. SPOSATI, Aldaíza. Tendências latino-americanas da política social pública do século 21. In: Revista Katálisis. Florianópolis. Volume 14, n. 1, p. 106. Por sua vez, FLEURY indica ainda que o modelo Uruguaio até a década de 50, apresentou um singular caso no contexto latinoamericano, com alto grau de urbanidade, crescimento da classe media, baixas taxas de mortalidade, com crescimento da economia e distribuição de riqueza. In: FLEURY, Sônia. O Estado sem cidadãos. Seguridade Social na América Latina. (...). p. 178.

32 HUBER, Evelyn. Options for social policy in Latin America: Neoliberal versus democratic models. (...) p.153-159.

33 MESA-LAGO, Carmelo. Models of Development, Social Policy and Reform in Latin America. pp. 182. 
enquanto o segundo buscou um modelo universalizador. ${ }^{34}$

A política social na América Latina se encontra hoje em uma encruzilhada: pode optar por um modelo "liberal", com maior foco nas determinações do mercado e da atuação privada ou pode optar por um modelo público, com controle exercido pelo Estado. Nos anos 80, devido à hegemonia neoliberal no setor financeiro e bancário, e na burocracia e governo de importantes países latino-americanos fez com que houvesse uma inclinação para os modelos neoliberais. ${ }^{35}$ Contudo, em face dos custos sociais decorrentes da opção pela via neoliberal, assim como em vista dos resultados decorrentes da abdicação das responsabilidades sociais, associados a questões de governabilidade nas novas democracias, os modelos públicos de políticas sociais voltaram à tona tanto em âmbito de instituições internacionais como também nos governos locais. ${ }^{36}$

Como se verá no tópico a seguir, após algumas décadas de construção de um sistema de proteção social nacional, o modelo brasileiro inaugurado pela Constituição Federal de 1988 terá formulações específicas e buscar, de forma geral, construir e consolidar o dever do Estado como garantidor de direitos sociais.

\subsection{Histórico da política social no Brasil}

Nesse item, será analisada, ainda que de maneira breve, a evolução da política social nacional, e como a Constituição Federal de 1988 buscou alterar, em vários aspectos, os paradigmas encontrados no modelo anterior de garantia de direitos sociais.

Pela exposição já feita acima, percebe-se que nem sempre foi clara a noção de que o Estado tinha a responsabilidade de lidar com a questão social. No Brasil, a questão da pobreza e desigualdade revestiu-se de uma particularidade: a escravidão.

Não há dúvidas que a abolição da escravidão, no território nacional, teve grande impacto sobre a politização e discussão das questões sociais. O surgimento do trabalho livre e a luta por melhores condições de vida e trabalho apareceram, nesse contexto, como situações suscetíveis de debate e negociação. Mesmo em face da predominância de

34 HUBER, Evelyn. Options for social policy in Latin America: Neoliberal versus democratic models. (...) pp.141-142.

35 HUBER, Evelyn. Options for social policy in Latin America: Neoliberal versus democratic models (...) p.141.

36 HUBER, Evelyn. Options for social policy in Latin America: Neoliberal versus democratic models. (...) p. 141 . 
abordagens repressivas e violentas, tanto por parte do poder público como também em relações privadas, o direito liberal garantido na constituição e em leis ordinárias permitia a abertura para negociação. ${ }^{37}$

Progressivamente, nas primeiras décadas do século XX, vão surgindo aberturas por parte de classes dominantes e do poder estatal, no sentido de admitir que a questão social fosse vista como um problema político, e não como uma problema a ser resolvido através da repressão. Todavia, mesmo após se entender que a questão social não era caso de polícia, e que passou a ser entendida como alvo de políticas públicas, tal fato não significou a completa ausência da força policial: a violência nunca deixou de fazer parte das alternativas de resposta estatal.

Dessa forma, a compreensão de que a questão social poderia ser alvo de políticas públicas somente aumentou o repertório de respostas; superou-se um paradigma de atuação estatal voltado somente para respostas negativas e repressão, mas não se excluiu tal atuação como uma possibilidade. ${ }^{38}$

No Brasil, foi a partir da década de 30 que surgiu um conjunto de leis referentes à criação de órgãos ligados a políticas sociais e à garantia de direitos trabalhistas. ${ }^{39}$ Em 1930, é criado o Ministério do Trabalho, criando-se a partir daí, um sistema corporativo, por meio da legislação e sindicalização. Passou-se, portanto, ao início da regulamentação das relações de trabalho, dando origem à conformação inicial de um sistema social do tipo conservador, onde os critérios de inclusão e exclusão dos benefícios sociais dependiam da posição ocupacional e do rendimento. Todavia, mesmo assim a legislação da época apresentou um avanço para a regulação das relações de trabalho, tendo em vista que partiu da completa inexistência de garantias, que caracterizava o trabalho rural da época ${ }^{40}$.

$\mathrm{Na}$ década de 30 também foram criados as Caixas de Aposentadoria e Pensão $(\mathrm{CAP})^{41}$ e os Institutos de Aposentadorias e Pensões (IAP), voltados para a cobertura da perda, temporária ou duradoura, da habilidade para o trabalho, como velhice, doença, deficiências e pensões, além de organizar o sistema de saúde. Os IAPS eram organizados por meio de categoria ocupacional, e de acordo com diferenças regionais e locais, o que

\footnotetext{
IANNI, Octavio. A questão social. São Paulo em Perspectiva. 5 (1): 2-10, janeiro-março de 1991.p. 3. FLEURY, Sônia. O Estado sem cidadãos. Seguridade Social na América Latina. (...) p. 129. CASTRO, Jorge Abrahão de; RIBEIRO, José Aparecido; CAMPOS, André Gambier; MATIJASCIC, Milko. A CF/88 e as políticas sociais brasileiras. (...) p. 59.

40 ROJAS COUTO, Berenice. O Direito Social e a Assistência Social na Sociedade Brasileira: Uma equação possível? $4^{a}$ edição. São Paulo: Editora Cortez. 2010. p. 96.

41 As CAPS permaneceram até 1953, para categorias de menor força organizativa e financeira.
} 
deu origem a um sistema heterogêneo de benefícios. ${ }^{42}$

Entre as décadas 30 e o final da década de 70, o Brasil construiu um sistema de políticas sociais que pode ser compreendido sob a noção de Estado de Bem Estar Social. É possível se chegar a essa conclusão como decorrência de diversos fatores: gasto social público variando entre 15 e $18 \%$ do PIB; grande contingente de usuários dos serviços prestados; programas cuja estruturação remonta aos sistemas modernos de proteção social presentes nas sociedades urbano-industriais - como a conjunção de programas de transferência de renda e de prestação universal de serviço; diversidade institucional, decorrente da estruturação de redes de serviços, com organismos de tamanhos e pesos variados, além da formação de uma burocracia profissional; e, finalmente, a integração dos programas e serviços públicos fornecidos aos jogos políticos. ${ }^{43}$

Contudo, em que pese a construção paulatina por quase cinquenta anos, o sistema de proteção social estabelecido apresentou baixa capacidade de edificação do caminho à equidade, devido a sua pouca capacidade de incorporação dos excluídos - principalmente os trabalhadores urbanos empobrecidos e os trabalhadores rurais -, aos programas que pouco contribuíam para a redução das desigualdades sociais, os benefícios e políticas que reforçavam privilégios, ainda que embasados em ideias universalistas, e a expansão quantitativa dos serviços dissociada da melhoria de qualidade. Nota-se que, entre as décadas de 30 e final da década de 70, a redução de pobreza e desigualdade deveu-se grandemente a altas taxas de crescimento econômico, emprego assalariado e mobilidade social, sendo o papel das políticas sociais reduzido. ${ }^{44}$

Efetivamente, em que pese a produção nacional no período entre 1930 e 1980 ter crescido de forma considerável, permitindo a consagração de uma nova estrutura produtiva no pais, tal crescimento não mostrou reflexos na redução da pobreza, na criação de um mercado de trabalho mais igualitário e atenuações das desigualdades. Dessa forma, o rápido crescimento econômico não foi associado à construção de uma sociedade mais justa e igualitária. $^{45}$

42 MATIJASCIC, Milko. DRAIBE, Sônia Miriam. The Market orientation of social security. Caderno de pesquisa n. 44. Núcleo de Pesquisa de Políticas Públicas. Universidade Estadual de Campinas. 1998. P. 1.

43 DRAIBE, Sônia Miriam. O sistema brasileiro de proteção social: o legado desenvolvimentista e a agenda recente de reformas. Caderno de pesquisa n. 32. Núcleo de Pesquisa de Políticas Públicas. Universidade Estadual de Campinas. 1998. pp. 2-3.

44 DRAIBE, Sônia Miriam. O sistema brasileiro de proteção social: o legado desenvolvimentista e a agenda recente de reformas. (...) Pp. 3-4.

45 POCHMANN, Marcio. Proteção Social na Periferia do Capitalismo. Considerações sobre o Brasil. São Paulo em perspectiva. 18 (2). 2004, p. 8. 
A partir de 1964, a influência da modernização autoritária por parte do Estado fez imergir as políticas sociais nacionais no modelo excludente e concentrador já prevalecente no desenvolvimento econômico. Os grupos vulneráveis que mais necessitavam dos programas e benefícios não eram atingidos, o conteúdo corporativo na condução da política e na definição de prioridades era claro e era muito comum a distribuição de recursos tendo por base práticas clientelistas. Dessa forma, ao sancionar um histórico nacional em que a desigualdade prevalece, o sistema social brasileiro reafirmava seu caráter conservador e demonstrava sua incapacidade em atuar sobre tais desigualdades. ${ }^{46}$

Nota-se ainda que a receita utilizada pelo Estado a fim de financiar o gasto social era formada principalmente pelas contribuições de trabalhadores e empregadores advindos do mercado formal de trabalho, grupo este consideravelmente reduzido. Tal forma de intervenção social por parte do Estado acabava, portanto, por reproduzir as desigualdades já existentes na sociedade, já que espelhava a divisão primária de renda, obtida por intermédio do trabalho formal. Ademais, a estrutura do mercado de trabalho e a existência de salário tendencialmente baixos afetavam a extensão e qualidade dos serviços prestados, que se mostrou insuficiente para atuar de forma adequada sobre imensa demanda por serviços sociais. $^{47}$

A rápida inserção de parcelas cada vez maiores da população, gerando um grande número de pessoas usuárias dos serviços ligados à proteção social, são também duas marcas da construção do sistema de proteção social brasileiro. A inclusão de grandes contingentes populacionais se deu praticamente durante o curto período de uma década da metade da década de 70 até a metade da década de 80 - e os programas sociais criados demonstraram ser programas de massa, afetando grandes contingentes populacionais, mesmo quando se tratava de programas focalizados sobre certos grupos. Esse aspecto se mostra até hoje problemático dentro da política social nacional, qual seja, a necessidade de ter que se lidar com grandes números, tanto no que toca à articulação institucional, passando pela gestão de monitoramento de serviços, chegando, por fim, à necessidade de manutenção da qualidade do serviço mesmo em face de expansão dos programas e usuários. $^{48}$

46 DRAIBE, Sônia Miriam. O sistema brasileiro de proteção social: o legado desenvolvimentista e a agenda recente de reformas. (...) 1998. P. 4-7.

47 POCHMANN, Marcio. Proteção Social na Periferia do Capitalismo. Considerações sobre o Brasil. (...) p. 10.

48 DRAIBE, Sônia Miriam. O sistema brasileiro de proteção social: o legado desenvolvimentista e a agenda recente de reformas. (...) pp. 9-10. 
Após uma década de crescimento econômico acentuado, conhecido por milagre econômico, a década de 80 revelou um país com enormes dificuldades geradas pela grande concentração de renda e pela baixa capacidade de participação na riqueza nacional. ${ }^{49} \mathrm{O}$ padrão de desenvolvimento econômico ocorrido durante o período dos governos militares, além de não atenuar as condições pobreza no país, introduziu e reforçou novos padrões de reprodução de desigualdade social e empobrecimento. Os padrões desiguais de pobreza, já graves no início da década de 60 , acentuaram-se no início da década de 80 . O mesmo pode ser dito quanto à pobreza absoluta. ${ }^{50}$

Em resumo, até a década de 90, a construção de um sistema de proteção social no Brasil não se deu de forma a consolidar os interesses em torno de um pacto de cidadania, com vistas aos princípios de igualdade e justiça social, tendo em vista a grande ênfase dada à necessidade do vínculo formal de trabalho. ${ }^{51}$

Dessa forma, a Constituição Federal de 1988, ao ser promulgada, encontrou um desafio pela sua frente no tocante às políticas sociais: em face do sistema anterior, para se romper a dívida social criada, era necessário encontrar "mecanismos estáveis de financiamento que permitissem elevar os valores dos benefícios, a qualidade do atendimento e, em última instância, a cidadania, sem sujeitar a política social aos desígnios da política econômica., ${ }^{, 52}$

Nos 20 anos que se seguiram à prolação da Constituição, houve a reestruturação do Estado democrático de Direito, e o legado dos movimentos sociais permitiu a construção de um sistema social que se opunha ao pensamento neoliberal predominante à data de sua promulgação. Contudo, desde o início da década de 90, os direcionamentos da política social nacional se encontraram em face de tensões entre dois paradigmas antagônicos: o neoliberal, que prevalecia no plano internacional, e os embrionários dispositivos de um

49 ROJAS COUTO, Berenice. O Direito Social e a Assistência Social na Sociedade Brasileira: Uma equação possível? (...) p. 137.

50 Relatório sobre a situação social do país. Brasil 1985, volume I. Núcleo de Estudos em Políticas Públicas - Instituto de Economia da Unicamp. P. 16.

51 FLEURY, Sônia. O Estado sem cidadãos. Seguridade Social na América Latina. (...) 234-235.

52 Os males dos programas sociais implementados até aquele momento foram identificados, de uma forma geral, com três aspectos. O primeiro deles referia-se à falta de planejamento e coordenação, com superposição de competências entre os entes da federação e a indenização de prioridades. $\mathrm{O}$ segundo, ligava-se à pouca capacidade redistributiva das políticas sociais. Por fim, o terceiro aspecto relacionavase com a falta de critérios transparentes para a alocação de recursos e de mecanismos de fiscalização e controle mais modernos. In: CASTRO, Jorge Abrahão de; RIBEIRO, José Aparecido; CAMPOS, André Gambier; MATIJASCIC, Milko. A CF/88 e as políticas sociais brasileiras. (...) pp. 63-64; 70-75. 
Estado de bem-estar social contido em seu bojo. ${ }^{53}$

Todavia, alguns aprimoramentos puderam ser notados: a estabilização econômica gerou seus benefícios e a proposta que se seguiu no governo federal a partir de 2003, com a ação distributiva por parte do Estado, teve alguns efeitos ${ }^{54}$. Nesse sentido, percebe-se que desde o ano de 2000, a desigualdade no Brasil vem se reduzindo, tendo em 2012, apresentado marca histórica. ${ }^{55}$ A renda dos mais pobres no período 2001-2011 também cresceu de forma impressionante. ${ }^{56}$

Em resumo, apesar de ainda existirem graves problemas no que toca ao campo social, não se nega, contudo, os grandes ganhos para o sistema de proteção social decorrentes da promulgação da Constituição Federal de 1988, como será visto a partir dos tópicos seguintes.

\subsection{Políticas da Assistência Social}

Dentre as contribuições decorrentes da promulgação da Constituição Federal de 1988, podemos citar os ganhos para área da Assistência Social.

Nesse tópico, será investigada as origens da assistência social, e como no passado, a assistência era vista como equivalente à ação caridosa, voluntária e eventual, vinculada geralmente à noção de "favor", e não de direito. A partir de certo momento, há uma alteração do modelo assistencial e, no Brasil, a partir da promulgação Constituição Federal de 1988, se cunha a ideia de que a assistência social é um direito, e que esse direito deve ser assegurado por meio da atuação do Estado.

\subsubsection{Assistência Social: funções e atribuições}

53 Dentre os elementos ligado a esses paradigmas antagônicos o autor cita as noções de universalização versus focalização, prestação estatal de serviços versus privatização e direitos trabalhistas versus desregulamentação e flexibilização como características desses dois paradigmas. In: FAGNANI, Eduardo. Direitos Sociais no fio da navalha. p.23.

54 SINGER, André. Raízes sociais e ideológicas do Lulismo. Novos Estudos, n. 85, novembro de 2009, p. 96-98.

55 Os cálculos de redução da desigualdade foram feitos com base no índice de GINI, que indicou que em 2012, o Brasil atingiu marca recorde, tendo passado de 0,596 em 2001 para 0,519 em janeiro de 2012. NERI, Marcelo Cortês (coord.). De volta ao país do futuro: Projeções, crise europeia e nova classe média. FGV/CPS. Rio de Janeiro, 2012. p. 32-38.

56 Cf. Panorama Social da América Latina. Documento Informativo. 2013. Comissão Econômica para a América Latina e Caribe/Organização das Nações Unidas. CEPAL/ONU. p. 7, 11. 
A política assistencial, vista de forma geral, constitui a forma ancestral da política social, tendo precedido todas as demais formas de intervenção social por intermédio do Estado. A assistência social pública prestada aos pobres, na forma como fora implementada ao início da época moderna, além de dar início ao controle social e regulação estatal, trouxe ao Estado o dever de zelar pela sobrevivência, ainda que em seu grau mínimo, das populações desprovidas de recursos familiares e comunitários, incapazes de prover a própria subsistência por meio do mercado de trabalho. Tal forma primária de prestações sociais por meio do Estado associou-se à ação voluntária e caridosa oferecida por pessoas e instituições, caracterizando as ações estatais pelas mesmas características inerentes a tal prestação privada de serviços, quais sejam, sua instabilidade e falta de perenidade. Além disso, os serviços prestados possuíam caráter assistencialista, paternalista e autoritário, revestidos sempre pela ideia de "favor" e "doação". 57

Cabe aqui ressaltar o viés populista e benevolente deste antigo modelo assistencial, que se apresentava como mecanismo de reiteração da subordinação a que já se encontram submetidas as pessoas mais empobrecidas. ${ }^{58}$

Dessa forma, a prestação assistencial, em seus primórdios, buscava auxiliar aqueles indivíduos que se encontravam em situação de pauperismo, já que a pobreza era vista como necessária e até desejável, pois incentivava o trabalho por parte das classes mais baixas. Dessa forma, só eram auxiliados aqueles que se encontravam abaixo da situação de pobreza, valendo-se da situação da less eligibility ${ }^{59}$. Ressalte-se o fato de que a assistência social tinha por base a compreensão de que aqueles que demandavam ajuda tinham falhas em seu caráter: o viés da prestação assistencial se mostrava claramente punitivo, pois ao indivíduo era conferida a proteção somente contanto que se reconhecia sua incapacidade pessoal para prover seu sustento e reprodução através do mercado. Com isso, a proteção social aos trabalhadores era prestada através de incentivos ao trabalho, por um lado, e através da punição àqueles que se mostravam insubordinados, por outro lado. Isso porque as medidas de proteção social, sob a visão liberal, não poderia funcionar como uma forma de premiação daqueles que não se adaptavam à nova lógica produtiva. ${ }^{60}$

\footnotetext{
57 DRAIBE, Sônia Maria. As políticas de combate à pobreza na América Latina. (...). p. 18.

58 SPOSATI, Aldaíza de Oliveira et al. A assistência na trajetória das políticas sociais brasileiras: uma questão em análise. 11 a edição. São Paulo: Cortez. 2011. p. 29-30.

59 Tal regra afirma que a proteção social será dada aqueles cuja situação não pudesse ser comparável às condições de uma pessoa em estado de extrema pobreza e destituição. Dessa forma, para que fosse auxiliada, era necessário estar presente certas situações, como velhice e doenças graves. 
No solo nacional, a assistência, de forma geral, se constituiu como um instrumento privilegiado do Estado para o enfrentamento da questão social sob a forma de ação compensatória das desigualdades sociais. A combinação entre repressão - e autoritarismo e assistência tem se evidenciado como uma prática histórica comum no enfrentamento das desigualdades sociais. ${ }^{61}$

Note-se que no Brasil, o caráter assistencial foi, durante um bom tempo, uma característica marcante dentro da ação do Estado no que tocava às políticas sociais. Nesse contexto, o assistencial se apresentava dentro das políticas de corte social por meio da ideia de emergência, entendida aqui como respostas estatais eventuais e fragmentadas, fazendo dos programas sociais, vistos de forma geral, o fruto de casuísmos. ${ }^{62}$ Isso porque em seu exercício prático, as políticas públicas dentro da Assistência Social acabavam sendo captadas, e limitadas, à sua aparência: como ajuda pontual e personalizada a grupos de maior vulnerabilidade social, como uma política paliativa e secundária dentro das políticas sociais. $^{63}$

Percebe-se que no Brasil, nos primórdios da própria assistência social pública, ela estava ligada à Legião Brasileira da Assistência (LBA), com o objetivo de primeiramente assistir as famílias dos pracinhas que lutaram na II Guerra Mundial. Após, o trabalho da LBA foi estendido à população pobre, principalmente através de programas voltados para a área materno-infantil. A LBA era coordenada pela primeira-dama, Darcy Vargas, e acabou conferindo o caráter clientelista e voluntarista da política assistencial brasileira ainda por muitos anos. ${ }^{64}$

Após a Segunda Guerra Mundial, houve alterações no que se refere ao quadro conceitual ligado à assistência social. Primeiramente, os programas assistenciais passaram a ser compreendidos como uma forma de exercício e concretização de direitos básicos da cidadania, e não mais como mera forma de atenuação da pobreza. Nesse contexto, o estatuto da cidadania é central, afastando-se dos preconceitos e aspectos negativos aos quais as prestações assistenciais eram vinculadas no passado. Contudo, em pese tal alteração conceitual, que se afasta das abordagens assistencialistas que prevaleciam no

61 SPOSATI, Aldaíza de Oliveira et al. A assistência na trajetória das políticas sociais brasileiras: uma questão em análise. (...) p. 27-29.

62 SPOSATI, Aldaíza de Oliveira et. al. A assistência na trajetória das políticas sociais brasileiras: uma questão de análise. (...). pp. 22-23.

63 YAZBEK, Maria Carmelita. Classes subalternas e assistência social. $7^{\mathrm{a}}$ edição. São Paulo: Cortez, 2009. fl. 63.

64 ROJAS COUTO, Berenice. O Direito Social e a Assistência Social na Sociedade Brasileira: Uma equação possível? (...) p.103. 
passado na prestação dos serviços assistenciais, há ainda enormes dificuldades em se consolidar as novas práticas assistenciais como forma de consolidação de direitos e de exercício da cidadania. ${ }^{65}$

No contexto nacional, com a promulgação da Constituição Federal de 1988, sob a égide da noção de Seguridade Social, cunhou-se a noção da assistência social como direito. ${ }^{66}$ Pode-se dizer que a partir de 1988, a assistência social é reconhecida como missão do Estado, quebrando a noção de que este somente possuía atuação supletiva nessa área. Ademais, desde 1988, houve diversos avanços no sentido de se consolidar como campo de ação do Estado, como se pode observar pela promulgação da Lei Orgânica da Assistência Social, em 1993, da Política Nacional da Assistência Social, em 2004, e do Sistema Único de Assistência Social, regulamentado em $2005 .{ }^{67}$

Como forma geral, pode-se entender que o conjunto de políticas e programas dirigidos à população carente constitui o campo da política pública identificado como política de assistência social. A diferença primordial deste campo em relação a outros campos da política social decorre do destinatário de tal política - a população carente - e também por se tratar a política assistencial de uma prestação incondicionada de serviços àqueles que necessitam: para que haja a prestação da assistência não é necessária a comprovação de vínculo empregatício, contribuição anterior ou mesmo pagamento pelos serviços prestados. Ademais, a gratuidade dos serviços assistenciais apresenta-se como outra alteração relevante dentro do conceito assistencial, pois releva uma das dimensões do que é um direito social. ${ }^{68}$

A assistência social pode ser entendida como uma forma de subsídio - técnico, financeiro, material, psicológico. É um campo de transferência que pressupõe que de um lado haja pessoas com necessidade e de outro que haja a possibilidade prestacional. Ao lado dos salários e dos tributos progressivos, a assistência social, do ponto de vista redistributivo, pode ser vista como uma forma de atenuar as desigualdades sociais. A assistência social busca atingir os mínimos sociais e prover a atenção estatal em situações de fragilidade. A definição do que se entende por mínimo a ser garantido dependerá “ $d a$ própria luta e da demanda da sociedade sobre o que considera e requisita como garantia

65 DRAIBE, Sônia Maria. As políticas de combate à pobreza na América Latina. (...) p. 19.

66 DRAIBE, Sônia Maria. As políticas de combate à pobreza na América Latina. (...) p. 19.

67 CARVAlHO, Maria do Carmo Brant de. A política da Assistência Social: novos desafios. Políticas Públicas em Debate. Ciclo de Seminários. Fundap em 30 de junho de 2009. p.2.

68 DRAIBE, Sônia Maria. As políticas de combate à pobreza na América Latina. (...) pp. 18-19 
da dignidade de cada um e do conjunto dos cidadãos". ${ }^{69}$

A política de assistência social tem natureza quase-universal; há um certo grau de seletividade para que se possa acessá-la tendo em vista a existência de um teste de renda que qualifica e permite o acesso. Ao mesmo tempo, superado tal requisito, tais serviços são extensíveis a toda população cidadã. Em que pese tal seletividade por meio da renda, a tendência é que os serviços prestados pela assistência adquiram conotações cada vez mais universalistas, o que se aproxima os direitos sociais ao direito à cidadania. ${ }^{70}$ Tal informação pode ser depreendida pelas disposições da LOAS, que garante o direito a um patamar mínimo de sobrevivência, com o objetivo de assegurar a todos cidadania plena. ${ }^{71}$

Historicamente, a assistência social foi o mais importante mecanismo através do qual os setores mais empobrecidos acessam serviços e recursos variados, como creches, cursos profissionalizantes, projetos voltados para geração de renda, de moradia, de atendimento do direito de crianças, adolescentes, pessoas em situação de rua, idosos, pessoas com deficiência, maternidade, tendo por alvo a situação de pobreza que um número cada vez maior de pessoas se encontrava. De forma geral, todas essas ações podem ser divididas em duas categorias diversas: a) ações de caráter imediato, complementar e compensatório, como são exemplos a assistência alimentar, a provisão de medicamentos, próteses, órteses, passagens, auxílio em dinheiro, profissionalização, encaminhamento a outros serviços, provisão de documentos, dentre outros; b) serviços de cunho educativo, comunitário e social, como centros infantis, creches, núcleos comunitários, centros de lazer, núcleos de trabalho, serviços voltados à provisão de moradia e de desenvolvimento de infraestrutura urbana e social. Trata-se de um conjunto diversificado de ações, que tem como objetivo auxiliar grupos também diversificados, mas que tem como ponto em comum situações de pobreza e espoliação. ${ }^{72}$

Dentre as ações acima descritas, pode-se destacar um mecanismo social de distribuição de serviços assistenciais, que é a renda mínima em dinheiro ${ }^{73}$, uma

69 SPOSATI, Aldaíza. Prefácio. In: YAZBEK, Maria Carmelita. Classes subalternas e assistência social. pp. 19-20.

70 DRAIBE, Sônia Maria. As políticas de combate à pobreza na América Latina. (...) p. 19.

71 OLIVEIRA, Cláudia Hochmann; PINTO, Maria Meira. Política de Assistência Social e Cidadania no Brasil hoje: alguns elementos para discussão. P. 54.

72 YAZBEK, Maria Carmelita. Classes subalternas e assistência social. $7^{a}$ edição. São Paulo: Cortez, 2009. fl. 67.

73 A renda mínima garantida tem como base teórica o pensamento liberal, compreendendo-se que o Estado tem o dever somente em garantir um certo grau de segurança social, complementando e agindo de forma residual a fim de suprir a parte que os indivíduos não fossem capazes de obter através do mercado, de recursos familiares ou comunitários. Em um viés contemporâneo, mas ainda conservador, entende-se que 
substituição de parte dos serviços e bens sociais por meio de uma alocação direita de recursos em dinheiro. ${ }^{74}$ Desde meados da década de 90 , veem surgindo diversos programas de transferência de renda, constituindo-se em um campo heterogêneo. Contudo, tal realidade vem se modificando a partir de 2003, após a tendência à unificação de benefícios iniciada com o Bolsa Família. ${ }^{75}$ Permanecem ainda programas como o BPC da LOAS e o Bolsa Família, além de programas estaduais e municipais específicos que ainda se mantiveram. $^{76}$

Nesse contexto em que práticas de transferência de rendas são comuns, é importante se ressaltar que o modelo assistencial que se apresenta como substitutivo da renda - forma compensatória - não pode representar o único benefício dentro da assistência social. Em que pese o fato de que numa sociedade de consumo o fato de não se ter renda apresenta-se, sem sombra de dúvida, como uma forma de vulnerabilidade, essa é somente uma das diversas formas pela qual um indivíduo ou uma família se encontram desprotegidas. Reduzir a ação da assistência social ao mero auferimento de renda, significaria igualar a política social à lógica de mercado. ${ }^{77}$

o papel do Estado seria fornecer uma renda mínima e alguns serviços básicos, como segurança pública e educação, deixando para o setor privado o fornecimento dos demais serviços. No campo progressista, há também uma concepção da renda mínima, partindo-se do pressuposto das mudanças no mundo do trabalho, associadas à época de crise e de reorganização tecnológica, levam à eliminação de postos de trabalho, desemprego, dentre outros. Tais alterações geram consequência na própria atuação da política social, pois introduz ruptura e afeta a integridade do sistema, separando aqueles que se mantém empregados e gozam de proteção e aqueles que não mais estão empregados e que portanto gozam de proteção incipiente ou até inexistente, que por decorrência acabam valendo-se dos serviços assistenciais. A renda mínima, sob a visão progressista, expressaria uma nova forma de distribuição de riqueza; com o seguro social se assentada o cada vez menos sobre a relação salarial, a renda auferida pelos indivíduos decorreria menos da esfera produtiva, surgiria uma nova forma de distribuição da riqueza social. Surgiria uma nova forma de solidariedade social, na qual ocorreria uma alocação universal de renda a todo e qualquer cidadão, independentemente de contribuição. Sob essa perspectiva, mudaria também o ideário de justiça inerente, valorizando-se a concepção de se assegurar-se o direito de todos participarem da distribuição da riqueza, também conhecido como justiça distributiva. Ademais, a garantia de recursos mínimos em dinheiro favorecem o exercício da liberdade e autodeterminação por parte dos indivíduos, que terão a opção de escolher seus gastos prioritários e os serviços entendidos como mais necessários, se opondo aos modelos autoritários e controladores tão comuns dentro da oferta dos benefícios sociais no passado. (In: DRAIBE, Sônia Maria. As políticas de combate à pobreza na América Latina. In: São Paulo em Perspectiva. Volume 4 (2). pp. 18/24. 1990. p. 21-22).

DRAIBE, Sônia Maria. As políticas de combate à pobreza na América Latina. (...) p. 19-20.

75 SILVA E SILVA, Maria Ozanira; YASBEK, Maria Carmelita; DI GIOVANNI, Geraldo. A Política Social Brasileira no século XXI: a prevalência de programas de transferência de renda. $6^{a}$ edição. São Paulo. Editora Cortez, 2012. pp. 203.

76 Maria do Carmo Brant de Carvalho considera que os benefícios monetários ou em espécie, no âmbito da assistência social, são fundamentais dentro de um sistema de proteção social. Contudo, questiona a predominância dos programas de benefícios em relação aos serviços ou à rede assistencial, entendendo que há uma defasagem entre essas duas formas de prestação sócio assistência. In: CARVALHO, Maria do Carmo Brant. A política da Assistência Social: novos desafios. Políticas Públicas em Debate. Ciclo de Seminários. Fundap em 30 de junho de 2009. p.8-9.

77 SPOSATI, Aldaíza. Horizontes da e para a Política de Assistência Social no Brasil de 2009: elementos 
Como já mencionado acima, o destinatário da assistência é definido por meio da marca da vulnerabilidade: a ausência de renda ou a renda precária; o trabalho precário, informal ou sazonal, o desemprego; o acesso precário ou inexistente a serviços públicos; a perda e fragilização de laços familiares e vínculos de pertencimento; discriminações de variados tipos, ou seja, todos fatores que ensejam vulnerabilidade social. ${ }^{78}$ Trata-se de uma população que, inserida ou não no mercado de trabalho, encontra-se em situação de dependência dos serviços públicos para sobreviver. Essa grande quantidade e diversidade de pessoas em situação de vulnerabilidade faz com que a todo momento o perfil dos usuários da política da assistência se redefina. ${ }^{79}$ Dessa forma, as demandas voltadas à Assistência Social acabam por abranger uma quantidade considerável de pessoas, não se restringindo a situações excepcionais. ${ }^{80}$

Contudo, o sistema assistencial, por conta de critérios e controles internos, acaba restringindo a entrada das pessoas que se encontram em estado de privação. Dessa forma, muitas pessoas pobres acabam ficando fora do sistema assistencial como decorrência da falta de informação ou recursos, negligência administrativa, ou mesmo por se sentirem estigmatizados pela mera busca de auxílio. ${ }^{81}$

O acesso à assistência social através de casos individuais realmente tende a ter esse efeito. Há até quem questione a prática assistencial que acaba se restringindo a essa abordagem, limitada a casos individuais, considerados singulares e emergenciais, ao invés de se tentar uma abordagem mais ampla e abrangente, focada na cidadania plena. $^{82}$

É importante destacar também que a política da assistência social não é auxiliar ou complementar às demais políticas sociais existentes; pelo contrário, tem responsabilidades próprias. Não se trata somente de agir como uma política voltada para as classes pobres, mas sim propriamente assegurar proteção social como direito e estabelecer um vínculo com a Seguridade Social. ${ }^{83}$

Contudo, apesar de suas próprias responsabilidades e trazer uma contribuição para

para discussão. Seminário Política de Assistência Social: novos Desafio. Fundap em 30 de junho de 2009. Políticas Públicas em debate. Ciclo de Seminários. pp. 15-16.

78 CARVAlHO, Maria do Carmo Brant. A política da Assistência Social: novos desafios. (...). p.2.

79 RAICHELIS, Raquel. Proteção Social e Trabalho do Assistente Social: tendências e disputas na crise mundial. Pp. 618-619.

80 SPOSATI, Aldaíza. A assistência social e a trivialização dos padrões de reprodução social. p. 21.

81 LAVINA, Lenas. Inclusão e progressividade: os desafios da Seguridade Social Brasileira. p.89.

82 OLIVEIRA, Cláudia Hochmann; PINTO, Maria Meira. Política de Assistência Social e Cidadania no Brasil hoje: alguns elementos para discussão. P. 54

83 SPOSATI, Aldaíza. Horizontes da e para a Política de Assistência Social no Brasil de 2009: elementos para discussão. Seminário Política de Assistência Social: novos Desafios. (...) p. 10. 
o enfrentamento da desigualdade social e da pobreza, assim como o fazem as demais políticas sociais, a assistência social não pode ser vista como solução para tal desigualdade. Isso não significa dizer que as políticas dentro da assistência social sejam intrinsecamente inefetivas ou inadequadas, mas sim entender que a solução da desigualdade na sociedade brasileira está além das possibilidades de atuação somente da assistência social. ${ }^{84}$

Para a efetivação do direito à assistência social, é essencial a figura do assistente social. Este poderá a prestar auxílio imediato à pessoa necessitada, mas também atuará também por intermédio de uma vertente sócio-educativa, mediando relações de confronto e conquista. Dessa forma, o assistente social terá duas opções: ou atuar sobre os destinatários da política social de forma "disciplinadora", ou colaborar no fortalecimento das demandas e lutas de tais grupos sociais, auxiliando no resgate de seu protagonismo. ${ }^{85}$

Nesse contexto, a assistência social adquire um duplo papel: ao mesmo tempo que se coloca como um mecanismo estabilizador das relações sociais, principalmente ao ser analisado pelo viés estatal, apresenta-se também como forma de acesso a recursos e serviços, além de ser um local onde se busca reconhecimento de direitos e de cidadania, viés esse buscado pelos assistidos. ${ }^{86}$ Nesse sentido, a assistência social é "uma forma de gestão estatal da força de trabalho e, nessa gestão, não só conforma o trabalhador às exigências da reprodução, valorização e expansão do capital, mas também é o espaço de articulação de pressões e movimentos sociais dos trabalhadores pela ampliação do atendimento de suas necessidades e reivindicações". ${ }^{87}$

Pelo tudo quanto o afirmado, a assistência social é, portanto, uma política pública, e isso significa quebrar com paradigmas ultrapassados. ${ }^{88}$ Contudo, está claro que o campo das políticas da assistência social não é homogêneo: há propostas paternalistas e assistencialistas, como também há propostas socioeducativas; há propostas que estimulam a participação dos usuários enquanto outras dão pouca abertura para essa participação. Há serviços prestados por meio de entidades assistenciais enquanto outros são prestados

84 SPOSATI, Aldaíza. Horizontes da e para a Política de Assistência Social no Brasil de 2009: elementos para discussão. Seminário Política de Assistência Social: novos Desafios. (...) pp. 6-7. YASBEK, Maria Carmelita. Classes subalternas e Assistência Social. (...) pp. 68-69.

86 YAZBEK, Maria Carmelita. Classes subalternas e assistência social. (...) pp. 64-65.

87 SPOSATI, Aldaíza; FALCÃO, Maria do Carmo. A prática da assistência Social. Elementos para uma caracterização. Serviço Social e Sociedade. Ano VI, n. 19, Dezembro 1985 apud YASBEK, Maria Carmelita. Classes subalternas e Assistência Social. $7^{\mathrm{a}}$ edição. São Paulo: Cortez, 2009. p. 64-65

88 SPOSATI, Aldaíza. Horizontes da e para a Política de Assistência Social no Brasil de 2009: elementos para discussão. Seminário Política de Assistência Social: novos Desafio. (...) p. 7. 
diretamente pelo poder público. ${ }^{89}$

Dessa forma, em que pese ter se constituído no plano do discurso como uma política social pública, a Assistência Social ainda tem obstáculos a superar. Já em pleno século, alguns desafios se apresentam para a política da Assistência Social. Primeiramente, mostra-se a necessidade da Assistência Social se afirmar como uma política universal, gerida de forma unitária por meio do Sistema Único da Assistência Social, evitando-se interferências partidárias. ${ }^{90}$ Em segundo lugar, precisa afirmar-se como política pública e autônoma, mas interligada e articulada às demais políticas sociais, buscando ações públicas conectadas. Essa ação articulada entre as políticas sociais se mostra essencial, já que os problemas sociais, por sua clara complexidade, exigem ações públicas multisetoriais, e que atinjam todos os tipos de vulnerabilidades. ${ }^{91}$

\subsubsection{Marco constitucional e regulamentação legal da Assistência Social}

Antes da Constituição Federal de 1988, a assistência social era estudada juntamente ao Direito do Trabalho, ou seja, não possuía autonomia. A lei 6.439/77, em seu artigo $9^{\circ}$, dispunha que competia à Legião Brasileira de Assistência (LBA) prestar assistência social à população carente mediante programas de desenvolvimento social e atendimento às pessoas. ${ }^{92}$ Os serviços assistenciais estatais eram escassos e o único benefício criado era a Renda Mensal Vitalícia ${ }^{93}$, para atender idosos com 70 anos ou mais e pessoas em situação de invalidez. As atenções assistenciais mantinham-se, em sua grande maioria, no campo privado. $^{94}$

Com a nova ordem constitucional, a política social assistencial aparece atualmente dentro do quadro instituído pela Constituição Federal de 1988, integrando o sistema da Seguridade Social, que é constituído também pelas áreas da Saúde e da Previdência Social.

89 YASBEK, Maria Carmelita. Classes subalternas e Assistência Social. (...) p. 70.

90 SPOSATI, Aldaíza. Horizontes da e para a Política de Assistência Social no Brasil de 2009: elementos para discussão. Seminário Política de Assistência Social: novos Desafio. (...) pp. 4-5.

91 CARVAlHO, Maria do Carmo Brant. A política da Assistência Social: novos desafios. (...) pp. 5-11.

92 MARTINS, Sérgio Pinto. Direito da Seguridade Social. 32a edição. São Paulo: Atlas, 2012. pp. 485.

93 JACCOUD, Luciana. Entre a pobreza e a cidadania: a política pública de assistência social no pós-88. p.257.

94 Conhecida também por "amparo previdenciário", a renda mensal vitalícia foi instituída por meio da lei n 6.179/74 e regido posteriormente pela Lei 8.213/1991. Correspondia à metade do salário-mínimo e era concedido aos maiores de 70 anos ou deficientes, incapacitado de forma definitiva para o trabalho e que não exercesse atividade remunerada ou tivesse rendimento superior ao valor da renda mensal de $60 \%$ do valor do salário-mínimo. In: MARTINS, Sérgio Pinto. Direito da Seguridade Social. 32a edição. São Paulo: Atlas, 2012. pp. 498. 
Conforme o disposto no artigo 194 da Constituição Federal, a Seguridade Social se propõe "universal, uniforme e equivalente para todas as populações rurais e urbanas, irredutivel em seus benefícios, com caráter democrático e descentralizado de gestão”.

A Seguridade Social pode ser descrita como um

\begin{abstract}
"Sistema de proteção aos indivíduos contra contingências que os impeçam de prover as suas necessidades sociais básicas e de suas famílias, integrado por ações de iniciativa dos Poderes Públicos e da sociedade, visando assegurar os direitos relativos à saúde, à previdência e à assistência social". 95
\end{abstract}

Cada uma das três áreas que integra a Seguridade Social - Previdência Social, Saúde e Assistência Social - é responsável pela atuação em uma frente: a Saúde é direito de todos, a ser assegurado de forma universal mediante acesso igualitário (artigo 196); a Previdência Social ${ }^{96}$ é organizada sob forma de regime geral, sendo de caráter contributivo e filiação obrigatória (artigo 201 e seguintes); por sua vez, a Assistência Social é prestada aos necessitados (artigo 203) ou aos desamparados (artigo $6^{\circ}$ ).

Dessa forma, a Assistência Social utiliza-se do critério referente ao mérito ou valor da necessidade, ou seja, somente aquelas pessoas que são socialmente reconhecidas como necessitadas ou desamparadas podem se valer dos serviços prestados pela Assistência Social. $^{97}$

A Assistência Social, volta-se, portanto, às pessoas fragilizadas, natural ou acidentalmente, tais como pessoas idosas ou com deficiência. É ainda no âmbito da Assistência Social que se instituiu o maior número de mecanismos não contributivos voltados à proteção social, reforçando-se a noção de direito do cidadão que se encontra em situação de vulnerabilidade. ${ }^{98}$

Apesar da ênfase colocada pela Constituição Federal, ao prever a Seguridade Social como integrada pela Assistência Social, Saúde e Previdência Social, não houve até o momento uma integração entre essas três faces da Seguridade Social. Há quem diga que o

95 MARTINS, Sérgio Pinto. Direito da Seguridade Social. (...) p. 21.

96 A previdência social abrange a cobertura de contingências ligas à doença, invalidez, desemprego, morte e proteção à maternidade, e exige contribuição, concedendo por consequências, pensões, aposentadoria, dentre outros. In: MARTINS, Sérgio Pinto. Direito da Seguridade Social. 32a edição. São Paulo: Atlas, 2012. pp. 23.

97 SPOSATI, Aldaíza. A assistência social e a trivialização dos padrões de reprodução social. p. 14. In: SPOSATI, Aldaíza. CARVALHO, Maria do Carmo Brant; FLEURY, Sônia Maria Teixeira. Os direitos dos desassistidos sociais. $7^{\text {a }}$ edição.

98 CARVALHO, Maria do Carmo Brant. A política da Assistência Social: novos desafios. (...) p.2 
ideal seria a criação de um Ministério da Seguridade Social, que concentraria os procedimentos administrativos referentes às três áreas, e não como ocorre nos dias de hoje, onde há Ministérios separados 99 .

Em outras palavras, o processo de centralização da previdência, do atendimento médico-hospitalar e da assistência social, que vinha ocorrendo desde 1966, foi revertido com a separação dessas políticas na órbita ministerial, o que dificultava, sem dúvida, a consolidação dos preceitos da seguridade social contidos na Constituição de $1988 .{ }^{100}$

Além dessa questão institucional, que insiste em encarar separadamente os ramos da Seguridade Social, a Seguridade Social se encontra hoje esvaziada também como decorrência do esmorecimento do debate acadêmico em torno de princípios integradores da Seguridade, e também como consequência da compreensão de que a política social é, por excelência, uma ação voltada somente a pessoas pobres (focalização). ${ }^{101}$

Entretanto, em que pese não tenha ocorrido a integração pretendida no âmbito da Seguridade Social, ainda assim essa aparece como um eixo pelo qual a Assistência Social se guia, principalmente com o fim de evitar retrocessos e continuar sua atuação sob um viés focado nos direitos e no dever do Estado em alcançar respostas universais. ${ }^{102}$

A partir da Constituição Federal de 1988, a Assistência Social passa a ter origem pública, ou seja, baseia-se na ideia de que ao Estado compete suprir as condições mínimas de sobrevivência àqueles que não tenham condições de subsistir, tendo em vista previsão constitucional (artigos 203 e 204 da Constituição de 1988). Contudo, a assistência social não é prestada somente por meio de entidades estatais, mas sim também por instituições particulares, que atuam sem fins lucrativos prestando atendimento aos usuários, além de atuar na defesa e garantia de seus direitos. ${ }^{103}$

Desde a promulgação da Constituição vigente, houve diversos avanços no sentido de regular e consolidar a atuação da Assistência Social como campo de ação estatal. O primeiro marco nessa direção deu-se com a promulgação da Lei de Assistência Social (Lei $\mathrm{n}^{\circ}$ 8.742, de 7 de dezembro de 1993), também conhecida como LOAS, com o consequente

99 MARTINS, Sérgio Pinto. Direito da Seguridade Social. (...) p. 27.

100 CASTRO, Jorge Abrahão de; RIBEIRO, José Aparecido; CAMPOS, André Gambier; MATIJASCIC, Milko. A CF/88 e as políticas sociais brasileiras. (...) p. 68.

101 WERNECK VIANNA, Maria Lúcia Teixeira. Seguridade Social: um conceito e uma prática da civilização (ainda) moderna. p.98-101.

102 SPOSATI, Aldaíza. Horizontes da e para a Política de Assistência Social no Brasil de 2009: elementos para discussão. Seminário Política de Assistência Social: (...) pp. 12-13.

103 MARTINS, Sérgio Pinto. Direito da Seguridade Social. 32ª edição. São Paulo: Atlas, 2012. pp. 486-487. 
refinamento de conceitos importantes dentro da nova abordagem pelo qual vem sendo compreendida a Assistência Social. ${ }^{104}$ Contudo, nota-se que já no início, a LOAS teve problemas: não foi aprovada no prazo previsto, principalmente tendo em vista restrições orçamentárias para o pagamento de um de seus benefícios, o Benefício de Prestação Continuada. $^{105}$

A Lei Orgânica da Assistência Social trouxe inovações ao apresentar novo desenho institucional para a assistência social, afirmando seu caráter não contributivo. Também apontou para a necessidade de integração entre o econômico e o social, dando enfoque à centralidade do Estado na universalização e garantia de direitos e de acessos a serviços sociais, mediante a participação da população. Propunha ainda o controle da sociedade na gestão e na execução das políticas de assistência. Por fim, a lei estabelece que a política da assistência social será descentralizada, constituída - nas três esferas de governo - por órgão gestores e por instâncias voltadas para a deliberação, bem como trata dos instrumentos para o planejamento, financiamento, controle social e gestão das atividades. $^{106}$

A LOAS foi essencial para indicar uma mudança substantiva quanto à concepção da assistência social, permitindo a passagem do assistencialismo - e da tradição de não política - para uma tradição de política pública, estabelecendo a primazia do Estado, e não mais de entidades privadas e filantrópicas, na responsabilidade da condução da política assistencial.

$\mathrm{O}$ artigo $4^{\circ}$ da LOAS dispõe sobre os princípios da Assistência Social e já de início reforça a supremacia do atendimento das necessidades sociais em relação à rentabilidade econômica. Dentre os demais princípios da Assistência Social há a universalização dos direitos sociais, o respeito à dignidade do cidadão, à sua autonomia e ao seu direito à prestação de benefícios e de serviços de qualidade. Prevê a convivência familiar e comunitária, vedando-se qualquer comprovação vexatória de necessidade, e a igualdade de direitos no acesso ao atendimento, sem discriminação de qualquer natureza, garantindo-se equivalência às populações urbanas e rurais. Por fim, afirma que deverá haver divulgação ampla dos benefícios, serviços, programas e projetos assistenciais, bem como dos recursos oferecidos pelo Poder Público e dos critérios para sua concessão.

104 CARVAlHO, Maria do Carmo Brant. A política da Assistência Social: novos desafios. (...) p.2

105 FAGNANI, Eduardo. Direitos Sociais no fio da navalha. p.23.

106 JACCOUD, Luciana. Entre a pobreza e a cidadania: a política pública de assistência social no pós-88. p. 257 
No que toca às entidades e organizações da assistência social, estas são reguladas pelas normas expedidas pelo Conselho Nacional da Assistência Social. ${ }^{107}$ O funcionamento das entidades dependerá de prévia inscrição no Conselho Municipal da Assistência Social do município ou no Conselho de Assistência Social do Distrito Federal. Tais Conselhos serão os responsáveis pela fiscalização de tais entidades e organizações sociais. A inscrição em face do Conselho responsável é condição para que se encaminhe um pedido de registro e de certificado de entidade beneficentes da Assistência Social em face do Conselho Nacional da Assistência Social. ${ }^{108}$

Dentre as medidas prevista pela LOAS, destaca-se o Benefício de Prestação Continuada $(\mathrm{BPC})^{109}$, que também vem previsto no artigo 203, inciso V, da Constituição Federal. Com a instituição do Benefício de Prestação Continuada, o benefício da renda mensal vitalícia foi extinto ${ }^{110}$.

O BPC representa a garantia de um salário-mínimo mensal à pessoa com deficiência e ao idoso com 65 (sessenta e cinco) anos ou mais que comprovem não possuir meios de prover a própria manutenção, nem de tê-la provida por sua família. O BPC fora uma das poucas medidas que se institucionalizou como direito, pois muitos benefícios e serviços acabam se tornando construções de governo, e não do Estado ${ }^{111}$. O BPC teve grande impacto no padrão de proteção social no campo da garantia de renda e atingiu um público que, em geral, se encontrava excluído. ${ }^{112}$

A partir de 2004, novas mudanças ocorreram na política de assistência social, com a aprovação da nova Política Nacional da Assistência Social (PNAS/2004) e com a consequente criação do Sistema Único de Assistências Social (SUAS).

Nota-se que mesmo já tendo ocorrido a aprovação da primeira Política Nacional da Assistência Social, em 1998, essa não conseguiu ter efetividade, pois sempre foi confrontada pelo Programa Comunidade Solidária, programa esse apresentado através da Medida Provisória n. 813 de 1995. O Programa Comunidade Solidária foi estabelecido de forma paralela à LOAS, como principal forma de enfrentamento da pobreza, quando em realidade caracterizou-se mais pelo seu apelo simbólico, com ações pontuais, sem se pautar

107 Artigo $7^{\circ}$ da lei 8.742/1993.

108 Art. $9^{\circ}$, caput e $\$ 2^{\circ}$ da lei $8.742 / 1993$

109 Artigo 20 e seguintes da lei 8.742/1993.

110 MARTINS, Sérgio Pinto. Direito da Seguridade Social. (...) p. 498.

111 SPOSATI, Aldaíza. Horizontes da e para a Política de Assistência Social no Brasil de 2009: elementos para discussão. (...) p. 14.

112 JACCOUD, Luciana. Entre a pobreza e a cidadania: a política pública de assistência social no pós-88. p.259. 
por princípios de universalidade dos direitos e da cidadania, desconsiderando os direitos conquistados e o objetivo de integrar a assistência social em um sistema de Seguridade Social. $^{113}$

Contudo, em 2004, com a Política Nacional da Assistência Social (PNAS/04) houve realmente avanços no que toca a efetivas mudanças dentro da Assistência Social. Surgida como decorrência das deliberações estabelecidas pela IV Conferência Nacional da Assistência Social, realizada em Brasília, em dezembro de 2003, a PNAS/04 teve por objetivo a padronização, melhoria e ampliação dos serviços assistenciais no Brasil, a fim de tornar claras as diretrizes a serem tomadas pela assistência social, sempre tendo por base o direito de cidadania e a responsabilidade do Estado. A PNAS/2004 reforçou a necessidade de ação articulada por parte da assistência social com outras políticas, apontando para a importância de ações integradas (intersetorialidade), ${ }^{114}$ e consolidou o processo de descentralização disposto na LOAS, criando novas responsabilidades para as esferas de governo e organizando uma nova sistemática de financiamento. ${ }^{115}$

Como decorrência das PNAS/2004, surgiu o Sistema Único da Assistência Social (SUAS). ${ }^{116}$ O SUAS buscou articular as três esferas de governo, de forma a integrar o sistema da assistência social de forma orgânica, a partir de uma gestão descentralizada e participativa. ${ }^{117}$ Além disso, inovou ao incutir uma nova racionalidade política, em que a centralidade são os serviços prestados e o cidadão. Dessa forma, rejeitou os paradigmas de gestão da assistência social recorrentes no passado, onde a ação fragmentada dos entes federativos era comum, e buscou reforçar a necessidade de uma gestão pactuada entre governos federal, estadual e municipal. ${ }^{118}$

Também acompanhando o PNAS, surgiu a Norma Operacional Básica (NOB/SUAS) de 2005, um outro avanço na política assistencial. A NOB/SUAS acompanha o PNAS e organiza dois níveis de proteção: a proteção social básica e a proteção social especial, esta última dividida em proteção com média complexidade e com

113 TELLES, Vera da Silva. No fio da navalha: entre carências e direitos. Notas a propósito dos programas de renda mínima no Brasil. p.30.

114 ROJAS COUTO, Berenice; YASBEK, Maria Carmelita; SILVA E SILVA, Maria Ozanira; RAICHELIS, Raquel. O Sistema Único de Assistência Social: uma realidade em movimento. $3^{a}$ edição. São Paulo: Editora Cortez. 2012. p. 59-61.

115 JACCOUD, Luciana. Entre a pobreza e a cidadania: a política pública de assistência social no pós-88. p. 257.

116 JACCOUD, Luciana. Entre a pobreza e a cidadania: a política pública de assistência social no pós-88. p.257.

117 Artigo $6^{\circ}$ da lei 8.742/1993.

118 CARVAlHO, Maria do Carmo Brant. A política da Assistência Social: novos desafios. (...) pp. 3-4. 
alta complexidade. ${ }^{119}$ Permitiu também a prestação de serviços também por intermédio de entidades sem fins lucrativos. ${ }^{120}$ Os serviços de proteção social básica serão oferecidas no Centro de Referência de Assistência Social (CRAS) enquanto os serviços de proteção social especial serão oferecidos no Centro de Referência Especializado de Assistência Social (CREAS), e por entidades sem fins lucrativos. ${ }^{121}$

Dentro da estrutura do SUAS, há órgãos de atuação deliberativa, de caráter permanente e composição paritária entre governo e sociedade civil: o Conselho Nacional da Assistência Social, os Conselhos Estaduais da Assistência Social, os Conselhos Municipais da Assistência Social e o Conselho de Assistência Social do Distrito Federal.

O Conselho Nacional da Assistência Social (CNAS) é o órgão superior de deliberação colegiada, e vincula-se à administração pública federal, responsabilizando-se pela condução da Política Nacional da Assistência Social. ${ }^{122}$ Dentre as atribuições do CNAS, há a obrigação de aprovar o Plano Nacional da Assistência Social, a normatização das ações e a regulação da prestação de serviços sócio assistenciais e o acompanhamento e a fiscalização do processo de certificação das entidades e organizações de assistência social no Ministério do Desenvolvimento Social e Combate à fome, estabelecer diretrizes, apreciar e aprovar os programas anuais e plurianuais do Fundo Nacional de Assistência Social - FNAS, dentre outras funções. ${ }^{123}$

Nesse contexto, tendo em vista sua atribuição, o CNAS aprovou em 2009 a sua Resolução $\mathrm{n}^{\mathrm{o}} 109^{124}$, que versa sobre a Tipificação Nacional dos Serviços Sócio

119 Assim, determinou-se que a proteção social básica será constituída pelo conjunto de serviços, programas, projetos e benefícios da assistência social que visa a prevenir situações de vulnerabilidade e risco social por meio de desenvolvimento de potencialidades e aquisições e do fortalecimento de vínculos familiares e comunitários. A proteção social especial por sua vez constitui-se por conjunto de serviços, programas e projetos que tem por objetivo contribuir para a reconstrução de vínculos familiares e comunitários, a defesa de direitos, e fortalecimento das potencialidades e aquisições e a proteção de famílias e indivíduos para o enfrentamento das situações de violações de direitos.

120 JACCOUD, Luciana. Entre a pobreza e a cidadania: a política pública de assistência social no pós-88. p. 257

121 O CRAS é uma entidade pública municipal, de base territorial, que se liga à prestação de serviços, programas e projetos sociais básicos a famílias, inserindo-se em locais de maior risco e vulnerabilidade social. Já o CREAS é uma entidade pública, municipal, regional ou estadual, voltando-se para a prestação de serviços a indivíduos e famílias que se encontram em situação de risco pessoal ou social, por violação de direitos ou contingência, que demandam intervenções especializadas da proteção social especial (Artigo 6-C, caput, $\S \S 1^{\circ}$ e $2^{\circ}$ da lei 8.742/1993).

Art. 17 da lei 8.742/1993

123 O rol completo das funções do CNAS encontra-se prevista no artigo 18 da lei 8.742/1993.

124 Especificamente no que toca à população em situação de rua, a Resolução 109 prevê os seguintes serviços, todos voltados à Proteção Social Especial: Serviço Especializado em Abordagem Social e Serviço Especializado para Pessoas em Situação de Rua, ambos com média complexidade; e Serviço de Acolhimento Institucional, Serviço de Acolhimento em Repúblicas e Serviço de Proteção em Situações 
assistenciais. ${ }^{125}$ Por meio dessa resolução, o CNAS buscou consolidar os padrões e as denominação de serviços sócio assistenciais no país, ${ }^{126}$ determinando que estes serão prestados diretamente pelos entes públicos ou, indiretamente, por meio de entidades vinculadas. ${ }^{127}$

A tipificação prevista na resolução $\mathrm{n}^{\circ} 109$ deverá ser incorporada pelos municípios, no momento de normatizar e implementar os serviços sócio assistenciais em âmbito municipal.

Note-se que dentre os serviços assistenciais, a LOAS prevê a criação de programas voltados especificamente às crianças, adolescentes e famílias, em situação de risco pessoal e social, idosos e deficientes, e também de programas voltados à população em situação de rua. $^{128}$

Através de todas as regulamentações editadas, ocorre novo giro quanto à definição e papel da assistência social: seus objetivos se estendem à garantia de renda e para o fornecimento dos serviços no campo da socialização, integração, desenvolvimento da autonomia e defesa em situação de violação de direitos. "O escopo da assistência passa a não mais ser compreendido em funções de grupos - como crianças, idosos ou indigentes mas sim em termos da segurança que essa politica de proteção social deve garantir."129

Percebe-se, portanto, que a partir da Constituição Federal, é editada uma série de diplomas legais, institucionalizando e regulando a política de assistência social,

de Calamidades Públicas e de Emergência, todos com alta complexidade.

125 Resolução $\mathrm{n}^{\circ}$ 109, de novembro de 2009, do Conselho Nacional de Assistência Social. Aprova a Tipificação dos Serviços Sócio assistenciais.

126 Quanto à proteção social básica, eram descritos os seguintes serviço: (i) Serviço de Proteção e Atendimento Integral à Família (PAIF); (ii) Serviço de Convivência e Fortalecimento de Vínculos; (iii) Serviço de Proteção Social Básica no Domicílio para Pessoas com Deficiência e idosas. Quanto à proteção social especial - média complexidade, era previstos: (i) Serviço de Proteção e Atendimento Especializado à Famílias Indivíduos (PAEFI); (ii) Serviço Especializado de Abordagem Social; (iii) Serviço de Proteção Social a adolescentes em cumprimento de medida socioeducativa de liberdade assistida (LA) e de Prestação de Serviços à Comunidade (PSC); (iv) Serviço de Proteção Social Especial para Pessoas com Deficiência, Idosas e suas Famílias; (v) Serviço Especializado para Pessoas em Situação de Rua. Quanto à proteção social especial - alta complexidade, era previstos: (i) Serviço de Acolhimento Institucional, nas modalidades Abrigo Institucional, Casa-Lar, Casa de Passagem e Residência Inclusiva. (ii) Serviço de Acolhimento em República; (iii) Serviço de Acolhimento em Família Acolhedora. (iv) Serviço de Proteção em Situações de Calamidades Públicas e de Emergência; Quanto à proteção social especial - alta complexidade, era previstos: (i) Serviço de Acolhimento Institucional, nas modalidades Abrigo Institucional, Casa-Lar, Casa de Passagem e Residência Inclusiva; (ii) Serviço de Acolhimento em República; (iii)Serviço de Acolhimento em Família Acolhedora; (iv) Serviço de Proteção em Situações de Calamidades Públicas e de Emergência.

127 Artigo 6-A, parágrafo único da lei 8.742/1993.

128 Artigo 23, $\$ 2^{\circ}$, incisos I e II, artigo 24 da lei 8.742/1993

129 JACCOUD, Luciana. Entre a pobreza e a cidadania: a política pública de assistência social no pós-88. p. 258 
consolidando, ainda, o dever do Estado, com auxílio da sociedade civil, no comando e na implementação dessa política. 


\section{POPULAÇÃO EM SITUAÇÃO DE RUA}

Nesse tópico do trabalho, serão discutidas algumas questões no que toca à população em situação de rua, como seu surgimento como tema a ser debatido na arena pública, o perfil da população de rua, assim como a evolução e os principais políticas públicas voltadas à essa população na cidade de São Paulo.

\subsection{A População em Situação de Rua como Questão Social}

O fenômeno da população em situação de rua data desde a formação das primeiras cidades brasileiras ${ }^{130}$. Entretanto, a população de rua se tornou uma questão social somente em momento mais recente. Trata-se de uma "invenção social" localizada no tempo, ao final da década de setenta e início da década de oitenta, onde ocorre "uma reconfiguração daquele antigo mendigo - cuja imagem ligava-se unicamente à prática circunscrita da mendicância nas ruas e ao fracasso moral e individual "131 , e o surgimento de uma questão política a ser trabalhada. Tal fenômeno se consolida efetivamente como questão social no início do século XXI.

A mudança no tratamento da situação dos moradores de rua vem ocorrendo como consequência da associação de dois fatores: o adensamento do número de pessoas que se encontram em situação de rua, como decorrência do agravamento da situação econômica, e a expansão da rede de atendimento a essa população, fator que lhes deu visibilidade política. ${ }^{132}$ A conscientização sobre os problemas econômicos e sociais - e a compressão da complexidade desses problemas - ligados à população que habitava as ruas, além da inserção dessas questões em um contexto de movimentos sociais e políticos teve por consequência a produção de discursos especializados, práticas e saberes, além de instituições específicas que demarcam a construção de um fenômeno novo. ${ }^{133}$

${ }^{130}$ Cf. CARVALHO, José Murilo de. Os bestializados: o Rio de Janeiro e a república que não foi. São Paulo: Companhia das Letras. 1987.

131 COSTA, Daniel de Lucca Reis da. A rua em movimento: Experiências urbanas e jogos sociais em torno da população em situação de rua. Dissertação de Mestrado. Faculdade de Filosofia, Letras e Ciências Humanas. Departamento de Antropologia. Ano de obtenção: 2007. Pag. 18-19.

132 FRAGELLA, Simone Miazara. Corpos urbanos errantes: uma etnografia da corporalidade de moradores de rua em São Paulo. Annablume, Fapespe, 2009. pp. 83-85.

133 MACHADO, Igor Rolemberg Gois. Violações de direitos humanos e cidadania categorizada: estudo de caso a partir da população em situação de rua do centro de São Paulo. (...) 2011. p. 61. 
É em meados da década de 70 que a questão da rua começa a se formar, mas ainda de forma tímida e não muito clara, além de misturada a outras questões. Surgem os primeiros estudos acadêmicos sobre o assunto ${ }^{134}$ e a articulação da sociedade civil se torna mais forte. Nesse momento, é possível situar a emergência daquilo que seria específico em relação ao mundo da rua, assim como a própria especificidade das pessoas que lá atuam e vivem.

Antes disso, o debate em torno das pessoas em situação de rua era pouco politizado, mas já existiam grupos, principalmente ligados à igreja católica, já inseridos no universo da rua.

De forma geral, a Igreja Católica sempre desempenhou um papel importante no que toca à assistência e a doutrinas de justiça social. No Brasil, desde o início do século XX, com o desenrolar das demandas anarquistas e socialistas no contexto operário, já havia o envolvimento de grupos de jovens católicos. Algumas décadas depois, já durante a ditadura militar desempenharam papel importante as comunidades eclesiásticas de base (CEBs), ligadas à experiência concreta decorrente de uma conjuntura política e social, principalmente nos desdobramentos e difusão da Teoria da Libertação. ${ }^{135}$

No que toca especificamente à população em situação de rua, desempenhou um papel essencial a ordem religiosa das Oblatas, ligada à Organização do Auxílio Fraterno (OAF). Essa organização foi uma das primeiras a trabalhar as questões ligadas aos moradores de rua no centro de São Paulo. Criada em 1955, a OAF se voltava a grupos vulneráveis de modo geral, como prostitutas e moradores de rua que andavam pelo centro da cidade. ${ }^{136}$ Com o passar do tempo, as práticas da OAF voltada para as pessoas pobres foi se alterando, e essa alteração foi essencial para o novo tratamento dado à questão da rua.

134 Em 1977, foi publicado um dos primeiros estudos sobre a população em situação de rua em São Paulo, Os mendigos na cidade de São Paulo, contemplando, sob um viés sociológico, a complexidade das atividades e ideologia características da mendicância. Cf. STOFELLS, Marie-Ghislaine. Os mendigos na cidade de São Paulo. Rio de Janeiro: Paz e Terra, 1977, p. 13.

135 Pode-se citar como exemplo, além da Juventude Operária Católica, ainda na década de 30, os esforços da Juventude Universitária Católica e Juventude Agrária Católica, já na década de 50. Após, tiveram grande peso os grupos ligados às Pastorais, como a Comissão Pastoral da Terra, a Comissão Pastoral Operária e a Comissão Pastoral Universitária. In: SOUZA, Luiz Alberto Gómez. A Igreja Católica e a Questão Social. São Paulo em Perspectiva. Volume 11, número 4, 1997. P. 76-87.

136

ALTEMEYER JUNIOR, Fernando. Compaixão em processos sociais e mudanças institucionais: o caso do vicariato episcopal do povo da rua em São Paulo. Doutorado em Ciências Sociais. Pontifícia Universidade Católica de São Paulo. São Paulo. Ano de Obtenção: 2006. Pp. 31-39; COSTA, Daniel de Lucca Reis da. A rua em movimento: Experiências urbanas e jogos sociais em torno da população em situação de rua. (...) Pag. 43-44. 
Em 1975, a OAF representava uma grande entidade assistencial a São Paulo, e possuía os melhores albergues. Sua prática era voltada mais para a acolhida, com casas de mulheres e casas de meninos, ou seja, não era muito pautada pela atuação nas ruas. Contudo, por decorrência das Conferências Latino-americanas em Medellín (1968) e Puebla (1979), e com a introdução da Teologia da Libertação, associadas à influência de Dom Paulo Evaristo Arns, as oblatas passaram a alterar sua forma de trabalho.

Dom Paulo chegou em São Paulo em 1966, na posição de bispo auxiliar. Posteriormente, em novembro de 1970, se tornou arcebispo. Ao chegar em São Paulo, acompanhava a OAF em suas vigílias da noite, e desde logo começou a se interessar pelo pobres e pelos presos, dois grupos que, naquela época, não vinham recebendo auxílio institucional por parte da igreja. Dom Paulo insistia na presença da igreja na rua, com o povo, demonstrando uma opção religiosa e uma mudança do lugar social da instituição. ${ }^{137}$

Já em meados da década de 70, em estudo realizado para a Pontifícia Comissão de Justiça e Paz da Arquidiocese de São Paulo, Dom Paulo apontava para a necessidade de ação concreta dos membros da Igreja, que não poderiam mais manter-se calados e inertes em face da pobreza e desigualdade que se alastravam na capital paulista já naquela época. Ressaltava a necessidade de uma tomada de consciência por parte da Igreja, e sua obrigação em se deslocar até a população pobre e se alinhar ao lado dos oprimidos, buscando uma participação efetiva do povo em seus destino. ${ }^{138}$

Nesse contexto de inovação de práticas, Dom Paulo, em uma conversa com líder das Oblatas, Griselda Castelvecchi (apelidada de "Nenuca"), solicitou que as oblatas “levassem Puebla às ruas". Isso gerou uma crise na OAF, e fez com o que grupo fechasse as casas de acolhimento e albergues que mantinha, se afastando dos trabalhos somente voltados para a acolhida. Após uma reconfiguração da sua forma de atuação, as oblatas tomaram a decisão de voltar para as ruas, assumindo a Teologia da Libertação como estilo de vida ${ }^{139}$. Partiram da ideia de organização popular, resgate da cultura e da religiosidade, com foco na convivência e na experiência compartilhada e na emergência de sujeitos autônomos. $^{140}$

137 ALTEMEYER JUNIOR, Fernando. Compaixão em processos sociais e mudanças institucionais: o caso do vicariato episcopal do povo da rua em São Paulo. (...) Pp. 33-35.

138 CAMARGO, Cândido Procópio Ferreira de [et al]. São Paulo 1975. Crescimento e pobreza. 13a edição. Edições Loyola, São Paulo. 1982.

139 CASTELVECCHI, G. (org.). Somos um povo que quer viver. São Paulo: Edições Paulinas, 1982. Pp.5-6.

140 ALTEMEYER JUNIOR, Fernando. Compaixão em processos sociais e mudanças institucionais: o caso do vicariato episcopal do povo da rua em São Paulo. (...) Pp. 42-45. 
Dessa forma, na década de 80, a OAF passou por uma alteração de suas práticas e uma redefinição de seu campo de ação: a partir desse momento, focaram suas atividades no centro da cidade e nas pessoas pobres que lá habitavam. Passaram a acompanhar a população de rua em seu cotidiano, andando pelas ruas do centro de São Paulo. Tratava-se das missões religiosas pelas ruas, que culminavam em momentos de celebração em praças públicas ou mesmo em igrejas. ${ }^{141}$

Em 1982, é escrito um livro sob o título Somos um povo que quer viver, ${ }^{142}$ relatando as experiências e o novo foco de atuação do grupo, que agora se direciona ao "povo sofrido e sem casa da região central". A articulação de experiências e saberes ao redor dessa população feitas pelo grupo das Oblatas foi, à época, a principal referência para diversos outros atores e organizações que lidavam com pessoas que moravam nas ruas. Foi também por intermédio dos conhecimentos adquiridos pelas oblatas que se desenharam novas formas de reconhecimento e visibilidade desses sujeitos. ${ }^{143}$

A nova proposta de atuação articulada pela OAF tinha por objetivo não mais ver os assistidos como objeto de sua prática, mas sim se valer de uma perspectiva comunitária. Surge ai a Comunidade dos Sofredores de Rua e o desenvolvimento de uma série de atividades ao seu redor: a Sopa do Glicério, o projeto Minha Rua Minha Casa, a estruturação de uma cooperativa de reciclagem, uma oficina de marcenaria e a Casa de Oração. ${ }^{144}$

Nessa época, ganha destaque a coleta de material reciclável, e a organização de cooperativas de reciclagem é estimulada por organizações como a OAF. As cooperativas são entendidas não só como uma forma de se ganhar dinheiro por meio da coleta e venda de material reciclável, mas também como uma oportunidade para a articulação política e a reivindicação de direitos. Em 1985, é criada a Associação e, em 1989, é criada a Coopemare (Cooperativa dos Catadores Autônomos de papel, Aparas e Materiais reaproveitáveis). ${ }^{145} \mathrm{~A}$ associação dos catadores de materiais sob a forma de cooperativa teve grande impacto sobre a imagem erroneamente constituída que enxergava os moradores de ruas como pedintes. Com o crescimento e articulação das associações de

141 ALTEMEYER JUNIOR, Fernando. Compaixão em processos sociais e mudanças institucionais: o caso do vicariato episcopal do povo da rua em São Paulo. (...) Pp.47-54.

142 CASTELVECCHI, G. (org.). Somos um povo que quer viver. São Paulo: Edições Paulinas, 1982.

143 COSTA, Daniel de Lucca Reis da. A rua em movimento: Experiências urbanas e jogos sociais em torno da população em situação de rua. (...) Pag. 45.

144 BARROS, Joana da Silva. Moradores de rua: pobreza e trabalho: interrogações sobre a exceção e a experiência política brasileira. p. 21.

145 FRANGELLA, Simone Miziara. Corpos errantes urbanos. (...) p. 79. 
catadores, foi reforçado o caráter de trabalhador dessas pessoas. As cooperativas de catadores também apontaram para uma nova forma de exercício da cidadania e autonomia, com protagonismo e valorização dos cooperados. ${ }^{146}$

Nesse contexto, as diversas questões que envolviam pessoas em situação de rua passaram a ser colocadas como problemas sociais e urbanos.

Após uma década de missões realizadas anualmente, nota-se que a partir de 1991, uma nova fase se inicia. Um marco importante, que demonstra a transição do tratamento da população de rua de questão religiosa - muito comum até o momento, principalmente como decorrência da articulação desenvolvida pela OAF - para uma questão política, se dá através do primeiro Dia de Luta da População de Rua, em maio de 1991, momento em que ocorre uma manifestação e a entrega de uma carta aberta à Prefeitura de São Paulo, exigindo-se do poder público direitos básicos para a população de rua. ${ }^{147}$

Os Dias de Luta revelam um momento de articulação, pressão política e expressão artístico-cultural. Eles aconteciam anualmente no mês de maio e tinham pautas políticas claras, exigindo políticas de inclusão e aprovação de leis voltada à população de rua. ${ }^{148}$

Dessa forma, através dos Dias de Luta, as práticas da Igreja pautaram-se pelo rompimento com a prática assistencial e buscaram o desenvolvimento de trabalhos focados na participação ativa dos moradores de rua, procurando a articulação dos recursos internos dos próprios moradores de rua. ${ }^{149}$

Pode-se observar claramente a alteração das práticas desenvolvidas pela Igreja. No início, se constrói através das sopas comunitárias e da ação da OAF. Após, é criada a Casa de Oração e demais espaços de reflexão e articulação. Desses espaços internos de reflexão, passa-se à expressão pública, através da manifestação políticas nas ruas, como ocorre nos Dias de Luta da população de rua. Observa-se um esforço nas práticas dos grupos religiosos que trabalhavam com a população em situação de rua no sentido de se afastar de valores e costumes paternalistas, que se produziam dentro da Igreja, para, de forma alternativa, buscar a articulação política, o reconhecimento da cidadania das pessoas em

146 DOMINGUES JÚNIOR, Paulo Lourenço. Cooperativa e construção da cidadania da população de rua. São Paulo: Edições Loyola/Editora Universitária Leopoldianum, 2003. Pp. 111-117.

147 COSTA, Daniel de Lucca Reis da. A rua em movimento: Experiências urbanas e jogos sociais em torno da população em situação de rua. (...) p. 86.

148 ALTEMEYER JUNIOR, Fernando. Compaixão em processos sociais e mudanças institucionais: o caso do vicariato episcopal do povo da rua em São Paulo. (...) Pp.55-56.

149 AMARAL, Denise Perroud. A Rede de Atenção à População em Situação de Rua: possibilidades de interferência na definição e concretização de uma política pública na cidade de São Paulo. Mestrado em Serviço Social. Pontifícia Universidade Católica de São Paulo. Ano de obtenção: 2010. Pp. 63-64. 
situação de rua, com o esforço permanente para atingir a participação ativa dessas pessoas, com rumo à autonomia. ${ }^{150}$

Contudo, é importante ressaltar que as práticas voltadas à autonomia e à politização dos temas voltados às pessoas em situação de rua não ficaram restritas somente à OAF. Elas vão se espraiar também para outros setores e organizações civis e religiosas atuantes na cidade de São Paulo.

Dentre essas organizações, destacam-se os trabalhos da Associação Rede Rua. Criada no início da década de 90 a partir da conjunção de movimento sociais e de diversas pastorais da igreja católica, a Rede Rua inicialmente tinha por objetivo servir como um centro de comunicação alternativa para movimentos sociais e grupos excluídos. Como consequência, foi criado o Centro de Documentação e Comunicação dos Marginalizados CDCM - visando, através da produção de vídeos, fotografias e notícias, denunciar e sensibilizar a sociedade em torno das pessoas em situação de rua. ${ }^{151}$

Em 1991, é criado o jornal O Trecheiro ${ }^{152}$, veiculado mensalmente, e voltado para a denúncia da violação de direitos humanos de grupos excluídos e vocalização de movimentos sociais. Mesmo após a mudança de seu nome, a Associação Rede Rua manteve o trabalho desenvolvido junto à população de rua. ${ }^{153}$

Outra organização que merece destaque é o Centro Gaspar Garcia de Direitos Humanos. Nascido da iniciativa de Pastorais Sociais e militantes que atuavam juntamente da população de rua do centro de São Paulo, o grupo desenvolveu atividades com catadores de materiais recicláveis e com moradores de cortiços. A partir de 1984, buscou o fortalecimento de trabalhos já existentes tendo por base a educação popular, tendo em seu ápice, em 1988, criado o Centro Gaspar Garcia. Essa organização tinha por objetivo demandar políticas públicas de moradia no centro, além de atuar no sentido de fortalecer a

150 ALTEMEYER JUNIOR, Fernando. Compaixão em processos sociais e mudanças institucionais: o caso do vicariato episcopal do povo da rua em São Paulo (...) Pp. 219-221.

151 http://www.rederua.org.br/rederua/.

152 Além do jornal "O Trecheiro", a Associação Rede Rua desenvolve outros projetos como o (a) Refeitório Comunitário Pena Fortes Mendes, localizado no Bairro da Bela Vista, que oferece 500 refeições ao dia à população em situação de rua; (b) Centro de Acolhida para Adultos 16 horas - Pousada da Esperança, localizado em Santo Amaro, que disponibiliza 120 vagas para pessoas em situação de rua; (c) Núcleo Santo Dias da Silva, também localizado em Santo Amaro, que disponibiliza 80 vagas, e desenvolve oficinas e proporciona o encaminhamento para cursos de profissionalização.

153 A mudança de nome - de Centro de Documentação e Comunicação dos marginalizados para Associação Rede Rua - ocorreu em 1998, após uma reformulação ocorrida dentro da própria organização. In: http://www.rederua.org.br/rederua/ 
mobilização da população de baixa renda que circulava pela região. ${ }^{154}$

Dessa forma, percebe-se que durante a década de 80 já havia algumas entidades civis que vinham trabalhando com a questão dos moradores de rua e procuravam desenvolver atividades voltadas para a garantia de seus direitos e de sua autonomia.

O próximo passo no sentido de politizar a questão das pessoas em situação de rua foi obter o apoio do poder público municipal. No governo Jânio Quadros, foram diversos os confrontos entre poder público e moradores de rua, principalmente em decorrência do trabalho dos catadores de materiais recicláveis. ${ }^{155}$ Contudo, a partir de 1989, com a eleição da Prefeita Luiza Erundina, o diálogo com o poder público se aprimora de maneira considerável.

Em realidade, a eleição de Luiza Erundina para Prefeitura de São Paulo em 1989 foi um marco em termos de tratamento da questão da população de rua. As primeiras atitudes da nova prefeita já revelam as novas intenções por parte do poder público no que toca a essas pessoas: em 1990, é assinado um decreto que regulariza o oficio de catadores de materiais recicláveis, quebrando com as práticas proibicionistas dos governos anteriores. Em 1992, ocorre o I Seminário Nacional da População de Rua de São Paulo, que teve por base uma pesquisa encomendada pela Prefeitura para mapear o perfil dos moradores de rua da cidade e que forneceu dados para orientar a prática de atendimento a essa população.

Desse seminário saiu a obra População de rua: quem é, como vive, como é vista ${ }^{156}$ que, ao ser publicada por meio de um discurso legítimo "ampliou, deu visibilidade e reorganizou a família de significados que até então caracterizavam o tema". Dessa forma, termos como "mendigo" e "indigente" deixaram progressivamente de ser utilizadas nos discursos públicos; no mesmo sentido, categorias como "povo de sofredores", originadas em um contexto de trabalho religioso com as pessoas que se encontravam em situação de rua, são substituídas por uma noção aparentemente mais neutra e politicamente mais operacionalizável: o conceito de população de rua. ${ }^{157}$

154 http://www.gaspargarcia.org.br/

155 DOMINGUES JÚNIOR, Paulo Lourenço. Cooperativa e construção da cidadania da população de rua. (...) p. 95.

156 Cf. VIEIRA, Maria Antonieta da Costa; BEZERRA, Eneida Maria Ramos; ROSA, Cleisa Moreno Maffei. População de Rua: quem é, como vive, como é vista. $3^{\circ}$ edição. São Paulo: Editora Hucitec. 2004.

157 COSTA, Daniel de Lucca Reis da. A rua em movimento: Experiências urbanas e jogos sociais em torno da população em situação de rua. (...) p. 93. 
Em 1993, foi elaborado o primeiro projeto de lei para regulamentar os serviços que já eram prestados à população de rua. Essa primeira iniciativa de regulação legal de serviços foi elaborada pela então vereadora Aldaíza Sposati e teve por inspiração as consultas feitas às organizações da rede de serviços prestados à população de rua, além dos próprios usuários dos serviços. O projeto foi apresentado em 1994, e aprovado em 1995. Entretanto, o Prefeito da época, Paulo Maluf, vetou a lei, e este veto só foi derrubado em 1997, no governo de Celso Pitta, por decorrência de pressões políticas e manifestações públicas, sendo sancionado e transformado na lei 12.316/97. Esse diploma legal teve papel importante para definir a população de rua como sujeito coletivo de direitos, pois o uso da identidade comum possibilita a visibilidade social, que se baseia na exposição e na utilização de códigos socialmente hegemônicos. ${ }^{158}$

Nota-se, portanto, que nos 4 anos do governo de Luíza Erundina houve possibilidade de diálogo e tentativa de garantir direitos à população de rua, enquanto nos governos que se seguiram praticamente não houve avanços em termos de institucionalização de políticas públicas para essa população.

Com a eleição da Prefeita Marta Suplicy, por sua vez, retomaram-se os avanços políticos. Como se verá a seguir, a Lei $\mathrm{n}^{\circ} 13.216$ foi regulamentada, e seguiu-se um vasto programa para a implementação efetiva de uma política pública para as pessoas em situação de rua.

Em um contexto de politização da questão ligada aos moradores de rua, um ator essencial nessa conjuntura foi o Movimento Nacional da População de Rua (MNPR). Fundado em 2004, o MNPR ganhou impulso após o Massacre da população de rua, ocorrido nos dias 19, 20 e 21 de Agosto 2004, na Praça da Sé, São Paulo. ${ }^{159}$ O principal objetivo $^{160}$ do MNPR é exigir a implementação da Lei de Atenção à População de Rua e

158 FRANGELLA, Simone Miziara. Corpos errantes urbanos. (...) p. 97.

159 No Massacre da Praça da Sé, 15 moradores de rua foram atacados com golpes na cabeça, sendo que 7 deles morreram. Os culpados nunca foram encontrados.

160 O MNPR coloca também como objetivos a luta contra todas as formas de preconceito, discriminação social, violação de direitos e da dignidade das pessoas em situação de rua; a apuração de crimes e violações de direitos da população em situação de rua; a transformação em lei do decreto que instituiu a Política Nacional para a População em situação de rua em 2009 e adesão dos municípios à Política Nacional; a Garantia de Programas de Habitação de Interesse Social e política de Locação Social em áreas centrais das cidades; a garantia ao Sistema Único de Saúde - SUS - e ampliação de ações de atendimento à Saúde Mental, com especial atenção às pessoas com transtorno decorrentes do uso de álcool e outras drogas; incentivo às formas de economia solidária e atividades cooperadas e associadas de trabalho, com proteção previdenciária; inclusão do tema população de rua no contextos dos direitos humanos em currículos escolares. In: Folder do Movimento Nacional da População de Rua. Realização: Movimento População de Rua e Instituto Pólis. Apoio Ministério do Desenvolvimento Social e Combate 
colocar a população "na frente do embate", veiculando aquilo que é pensado pela própria população de rua. ${ }^{161}$

O MNPR, ao lado de outros atores sociais, foi imprescindível para politizar a problemática em torno da população em situação da rua e buscar superar a visão ultrapassada de que essas pessoas precisam apenas de Centros de Acolhida ("albergues") e ações de assistência social. O Movimento defende a necessidade de políticas intersetoriais capazes de gerar alternativas para as pessoas que vivem na rua, de forma a se criar oportunidades nas áreas de trabalho, saúde, moradia, assistência, educação, direitos humanos, entre outras. ${ }^{162}$ Além disso, tendo em vista as particularidades da condições das pessoas que se encontram em situação de rua, o MNPR assume o papel fundamental de agir como "ponte" entre a sociedade e a rua, pois torna inteligíveis as demandas sociais vindas da rua ${ }^{163}$.

Contudo, o MNPR se vê em face da ambiguidade que simboliza a rua: ao mesmo tempo que é visto como um local marcado pela violência, carência e problemas, a rua também é vista como um local de criação e vivência. Dessa forma, ao colocar a noção de que a rua é um lugar indigno para se viver, o que gera por consequência reivindicar ações que visem a retirada desse contingente populacional desse local, o MNPR se vê na posição de ter que afirmar a rua como um direito daqueles que nela precisam morar para sobreviver - sendo contrária a uma política de expulsão de moradores de rua dos espaços públicos. A luta pelos direitos políticos da população de rua se coloca nesse intrincado contexto, pois afirmar a necessidade da rua é uma condição paradoxal da luta. ${ }^{164}$

Nesse contexto de alterações de significados e visões, os destinos de pessoas que se encontram na rua passam de questões meramente filantrópicas e religiosas, abordagens predominantes até meados da década de oitenta, se consolidam como questão social e passam a exigir novas formas de atuação, principalmente do Estado: políticas públicas. ${ }^{165}$ Pode-se dizer que o problema do morador de rua se transforma em uma questão social justamente a partir do momento em que é inscrito na agenda pública, sendo diversos os

à Fome.

161 COSTA, Daniel de Lucca Reis da. A rua em movimento: Experiências urbanas e jogos sociais em torno da população em situação de rua. (...) p. 114.

162 Construção de Políticas Públicas. O Trecheiro. Agosto de 2011. p. 4.

163 MNPR constrói diálogo com a sociedade. O Trecheiro. Outubro de 2011. p. 3.

164 COSTA, Daniel da Costa Reis da. A rua em movimento: Experiências urbanas e jogos sociais em torno da população em situação de rua. (...) pp. 180-181.

165 COSTA, Daniel de Lucca Reis da. A rua em movimento: Experiências urbanas e jogos sociais em torno da população em situação de rua. (...) p. 103. 
atores que colaboram nesse processo, como a mídia, a sociedade civil e a igreja. ${ }^{166}$

Dessa forma, foi por meio da interligação entre discursos, motivações, atores e instituições, encadeados em um percurso histórico de anos, que se constituiu uma rede de inteligibilidade que tornou possível a nomeação e visibilidade a essas questões, fornecendo instrumentos para lidar com o universo de relações que constituía o mundo da rua, universo esse que, até aquele momento, não era articulado de forma consistente:

"Numa concepção puramente pragmática, é razoável afirmar que antes desta gramática de relações ser tecida, não havia população de rua. Não que não existissem pessoas nas ruas, mas sim que era impossível nomeálas, observá-las, entendê-las como tais. As pessoas que viviam nas ruas, com passar dos anos, começaram a adquirir imagens mais sólidas, e a ganhar números, rótulos e classificações capazes de situá-las na ordem do discurso". 167

Dessa forma, observa-se que uma reflexão mais aprofundada e politizada sobre quem são as pessoas vivendo em situação de rua data de momento histórico recente; o mesmo podendo ser dito sobre a compreensão de que tais pessoas devem ser alvo de uma intervenção efetiva e perene através da atuação do Estado. Essa intervenção do Estado, como se verá a seguir, estruturou-se através da formulação de políticas públicas específicas, com a construção de uma rede de serviços voltados a essa população.

\section{2. População Em Situação De Rua: Principais Características}

Para que sejam desenvolvidas políticas públicas eficientes voltadas para esse novo contingente populacional que se apresenta em termos de questão social como População em Situação de Rua, é essencial primeiramente se definir ou compreender os limites de dada população, ou seja, suas características, seu perfil, suas formas de atuação, dentre outros aspectos.

Já de início, um dos desafios que se apresenta em termos de elaboração de políticas públicas para população de rua é circunscrever em um grupo definido e delimitado quem são tais pessoas, quais são suas origens e necessidades. Há uma grande diversidade de grupos em distintas localizações dentro da cidade, sendo uma de suas marcas principais a

166 GIORGETTI, Camila. Moradores de rua: uma questão social? São Paulo: Fapesp, Educ, 2010. p.254.

167 COSTA, Daniel de Lucca Reis da. A rua em movimento: Experiências urbanas e jogos sociais em torno da população em situação de rua. (...) Pag. 115-116. 
heterogeneidade desta população e das condições em que se encontra, o que torna difícil sua caracterização unívoca e imediata. ${ }^{168}$

Nesse sentido, a rua pode se constituir num abrigo para os que, sem recursos, dormem circunstancialmente em logradouros públicos, ou pode indicar uma situação na qual o espaço público representa seu habitat propriamente dito, onde se encontra estabelecida uma intricada rede de relações. Entretanto, o elemento unificador dessas situações e o que permite identificar tais pessoas como População de Rua são as condições de vida extremamente precárias ao se utilizar a rua, de forma circunstancial ou permanente, como abrigo ou moradia. ${ }^{169}$

Dentre os diversos grupos, pode-se citar pessoas com problemas de alcoolismo, desemprego crônico, portadores de HIV, pessoas com baixa auto-estima, com dificuldades de convivência coletiva, tuberculosos, dependentes químicos, ${ }^{170}$ imigrantes desempregados, egressos dos sistemas penitenciários e psiquiátricos, que constituem uma enorme gama de pessoas que utilizam as ruas como local de moradia e convivência. ${ }^{171}$

A definição fornecida pela Política Nacional de Inclusão Social da População em Situação de Rua (Decreto 7.053, de 23 de dezembro de 2009), para fins instrumentais, é a seguinte:

\begin{abstract}
“Grupo populacional heterogêneo, que possui em comum a pobreza extrema, os vínculos familiares interrompidos ou fragilizados e a inexistência de moradia convencional regular, e que utiliza logradouros públicos e áreas degradadas como espaço de moradia e de sustento, de forma temporária ou permanente, bem como as unidades de acolhimento para pernoite temporário ou como moradia provisória".
\end{abstract}

Além de seu perfil, também era preciso ter um indicativo da quantidade de pessoas na rua. Efetivamente, desde um primeiro momento, notou-se a necessidade de se mensurar essa população, que sequer é contabilizada por censos como o IBGE, devido à ausência de residência. Tal necessidade foi inclusive reiterada no I Encontro Nacional sobre a

\footnotetext{
168 Política Nacional para Inclusão da População de Rua. Brasília/DF. 2008. p. 8.

169 Política Nacional para Inclusão da População de Rua. Brasília/DF. 2008. p. 8; Cf. SILVA, Maria Lucia Lopes da. Mudanças recentes no mundo do trabalho e o fenômeno população de rua no Brasil 19952005. Tese de mestrado. 2006. Universidade de Brasília.

170 COSTA, Daniel de Lucca Reis da. Rua em movimento: Experiências urbanas e jogos sociais em torno da população em situação de rua. (...) p. 208.

171 Política Nacional para Inclusão da População de Rua. Brasília/DF. 2008. p. 8.
} 
população em situação de rua, ocorrido em Brasília em 2005. ${ }^{172}$

Em 2007, foi realizada uma pesquisa nacional censitária e por amostragem que se buscou calcular a quantidade de pessoas em situação de rua no país. O universo da pesquisa teve por base os municípios com população igual ou superior a 300.000 habitantes, além das capitais de Estado e o Distrito Federal. ${ }^{173}$ As cidades que já haviam realizado censos municipais específicos - São Paulo/SP, Belo Horizonte/MG, Porto Alegre/RS e Recife/PE - não foram incluídas na pesquisa. Ao final, foram selecionadas 71 cidades, dentre elas 23 capitais e 48 municípios com população igual ou superior a 300.000 habitantes, identificando-se 31.922 pessoas, maiores de 18 anos, em situação de rua. No total, considerando-se as pesquisas já desenvolvidas anteriormente pelas quatro cidades acima citadas, a quantidade de pessoas em situação de rua ultrapassava o número de 50.000 .

Na cidade de São Paulo ${ }^{174}$, o primeiro levantamento de que se teve conhecimento foi realizado em 1991 por profissionais da assistência social, que contabilizaram o número de pessoas que dormiam nos logradouros públicos da área central da cidade. No total, foram encontradas 3.392 pessoas. ${ }^{175}$ Além da contagem feita no período noturno, foi feita uma pesquisa qualitativa: foram preenchidos questionários com 532 pessoas, e os resultados indicaram que a grande maioria dos indivíduos (92\%) eram homens que viviam sozinhos, $70 \%$ tinha idade inferior a 40 anos, $50 \%$ eram brancos, $30 \%$ eram pardos e $20 \%$ eram negros; no passado, $87 \%$ já tinha trabalhado com carteira assinada, mas no momento de preencher o questionário, a grande maioria (85\%) realizava somente "bicos". Quanto à origem, $46 \%$ eram nascidos na região sudeste, sendo $28 \%$ naturais de São Paulo e $14 \%$ da capital. $^{176}$

Após essa primeira contagem, foram realizados mais três levantamentos em 1994,

172 Relatório do I Encontro Nacional sobre População em Situação de Rua. Ministério do Desenvolvimento Social e Combate à Fome. Brasília, DF, 2006, p. 83.

173 A pesquisa partiu da premissa de que há maior tendência de concentração de pessoas em situação de rua em municípios mais populosos e em capitais de Estados, por concentrarem mais recursos, serviços e possibilidades, e por isso, seriam locais presumivelmente mais procurados por pessoas em situação de vulnerabilidade que necessitem de oportunidades de emprego e condições mais favoráveis para a sua sobrevivência. In: Política Nacional para Inclusão da População de Rua. Brasília/DF. 2008. p. 9.

$174 \mathrm{O}$ artigo $8^{\circ}$ do Decreto 40.232/2001 estabelece a obrigação do Executivo Municipal em realizar um Censo da População de Rua até o terceiro ano da gestão, assim como realizar censos sobre essa população.

175 ROSA, Cleisa Moreno Maffei (org.). População de rua: Brasil e Canadá. São Paulo: Hucitec, 1995. p.54

176 SIMÕES JUNIOR. José Geraldo. Moradores de Rua. São Paulo: Pólis, 1992. pp. 35-37. 
1996 e $1998^{177}$, também sobre a responsabilidade da Secretaria Municipal de Bem Estar Social. Nessas contagens, além das pessoas localizadas em logradouros públicos, os profissionais também contabilizaram pessoas pernoitando nos albergues. O número total detectado em 1994 foi de 4.549 pessoas, passando para $5.334 \mathrm{em} 1996$ e $6.453 \mathrm{em} \mathrm{1998.}{ }^{178}$

A partir de 2000, estabeleceu-se uma parceria entre a Fundação Instituto de Pesquisas Econômicas (FIPE) e a Prefeitura de São Paulo, tendo sido realizados diversos estudos e censos relativos à população em situação de rua ${ }^{179}$.

Em 2000, foi realizada a primeira pesquisa censitária por intermédio da FIPE.

Neste primeiro censo, obteve-se a informação de que o número de pessoas em situação de rua na cidade era estimado em 8.706 pessoas, em sua maioria $-4.676^{180}$ concentrada no centro da cidade. Do número total, 5.013 pessoas se encontravam na rua, em logradouros públicos, enquanto 3.693 se encontravam em albergues ${ }^{181}$.

Em 2003, foi realizado um censo referente aos distritos centrais da cidade de São Paulo, procedendo também à contagem do número de pessoas em situação de rua. Essa pesquisa indicou a existência de 10.700 pessoas em situação de rua, sendo 6.186 em albergues e 4.208 em logradouros públicos. Em relação à 2000, constatou-se um aumento de 19,3\% do número de pessoas em situação de rua na cidade. Os homens ainda perfaziam a grande maioria das pessoas que moravam na rua, como $84 \%$. A principal alteração notada nessa pesquisa referiu-se a uma inversão no que toca à quantidade de pessoas que usavam albergues e aquelas que dormiam nas ruas: enquanto em 2000, mais da metade dos

177 Uma ressalva deve ser feita no que toca a essas primeiras contagens realizadas: houve diferença entre os critérios metodológicos adotados, especialmente no que toca os levantamentos de 1994, 1996, e 1998, com menor rigor metodológico quanto comparado às demais contagens, inclusive com aquelas realizadas posteriormente $(2009,2010$ e 2011). In: Varanda, Walter. Descartáveis urbanos: discutindo a complexidade da população em situação de rua e o desafio para as políticas de saúde. Revista Saúde e Sociedade. V. 1. P. 56-69. Jan-abr 2004. p.61.

178 VICTORIANO, Eliana Fernandes Loureiro. Projeto Oficina Boracea. Trabalho de Conclusão de Curso em Pós Graduação em Gestão Pública. Universidade Bandeirante de São Paulo. Ano de obtenção: 2008. p.20.

179 Primeiro censo da população em situação de rua na cidade de São Paulo, 2000; Perfil socioeconômico dos moradores de rua da área central, 2000; Censo dos distritos da área central, 2003; Estudo dos usuários dos albergues conveniados com a prefeitura, 2006; Avaliação dos serviços conveniados de atenção às pessoas em situação de rua, modalidades de albergues diurnos e albergues noturnos com núcleos de serviço, 2006; Censo da criança e adolescente em situação de rua na cidade de São Paulo, 2007; Perfil socioeconômico da criança e adolescente em situação de rua em duas subprefeituras da cidade de São Paulo: Sé e Pinheiros, 2007; Segundo censo da população em situação de rua na cidade de São Paulo, 2009; Perfil sócio econômico dos moradores de rua da área central, 2010.

180 Folder "Acolher: Reconstruindo vidas". Secretaria Municipal da Assistência Social. Prefeitura de São Paulo.

181 Os bairros com maior concentração apresentaram os seguintes números: Móoca (1.061), Brás (971), Sé (820), República (796), Liberdade (736), Santa Cecília (485), Santana (354), Tatuapé (328), Pari (318) e Santo Amaro (254). 
moradores de rua em São Paulo dormiam nas ruas (5.013 do total de 8.706), em 2003 a maior dos moradores de rua vinham usando os serviços de albergue (6.186 do total de 10.394). ${ }^{182}$

Essa alteração do número de pessoas que passaram a utilizar o serviço de albergagem indicou a importância de se utilizar os dados obtidos pelos censos na aplicação e desenvolvimento das políticas públicas. O grande aumento do número de pessoas que usavam os albergues entre os censos realizados entre 2000 e 2003 fez com que fosse necessário analisar o perfil das pessoas que estão utilizando esse serviço. Indicou também a necessidade de reformulação das políticas, para que sejam além de somente o albergue, como as moradias provisórias e definitivas (mutirões e demais programas habitacionais). ${ }^{183}$

Partindo da constatação de que o número de pessoas utilizando-se de albergues realmente tinha aumentado, em 2006 é realizada nova pesquisa pela FIPE, com o objetivo de obter o perfil dos usuários de albergues. Foram entrevistados 631 homens, em 22 albergues. Os dados foram coletados entre dezembro de 2005 e janeiro de 2006. A pesquisa não divergiu muito dos dados já obtidos em pesquisas anteriores, mas informou que o uso de drogas é mais comum entre os mais jovens (40\% dos homens entre18 a 29 anos) e o uso de álcool é mais comum entre os mais velhos (52\% dos homens entre 30 e 54 anos e $49 \%$ dos homens com mais de 55 anos).

A pesquisa notou o envelhecimento dos usuários de albergues, além do crescimento do número de idosos. Dentre os entrevistados, $74 \%$ trabalhavam e $5 \%$ tinham carteira assinada. ${ }^{184} 77 \%$ dos idosos tem problemas de saúde. Ressaltou-se também o problema de falta de atendimento de usuários de saúde. Ademais, foi identificada a falta de uma rede de serviços públicos que servisse como porta de saída das ruas, pois os serviços de albergue, isoladamente, não apresentavam saídas e possibilidade de inclusão. ${ }^{185}$

Novamente, importantes dados foram fornecidos devido à contagem e ao perfil das pessoas em situação de rua: indicou o crescimento no número de pessoas na rua, o envelhecimento de tal população - o que demanda novos cuidados - e a consequente

182 ALTEMEYER JUNIOR, Fernando. Compaixão em processos sociais e mudanças institucionais: o caso do vicariato episcopal do povo da rua em São Paulo. Doutorado em Ciências Sociais. Pontifícia Universidade Católica de São Paulo. São Paulo. Ano de Obtenção: 2006. P. 111.

183 Para transformar a realidade dos albergues. O Trecheiro. Abril-Maio de 2006. p. 3.

184 Dentre os jovens entre 18 e 29 anos, $73 \%$ trabalhava, e destes, $86 \%$ não tinha carteira assinada. Dentre os homens entre 30 e 54 anos, $72 \%$ e $96 \%$ destes não tinham carteira assinada. Dentre os homens com mais de 55 anos, 10\% recebe Benefício da Prestação Continuada. In: O Trecheiro. Fipe conclui pesquisa. Julho de 2006. p. 4.

185 E a saída das ruas? O Trecheiro. Outubro de 2006. p. 3. 
necessidade de prestação de serviços de saúde. Foi comprovado ainda que a grande maioria dessas pessoas trabalhava, em que pese se tratasse de vínculos, em geral, informais.

Em 2009, por meio de pesquisa realizada pela Fundação Instituto de Pesquisas Econômicas - FIPE e pelo Centro de Estudos Rurais e Urbanos - CERU em 2009-2010, realizou-se uma segunda contagem e obteve-se o Censo atualizado sobre a População em Situação de Rua. Em 2010, obteve-se o perfil socioeconômico de tais pessoas (Caracterização Socioeconômica da População de Moradores de Rua da Área Central de São Paulo). Essa nova leva de pesquisas indicou que o número de pessoas em situação de rua na cidade de São Paulo atingia um total de 13.666 pessoas, sendo maior a concentração de pessoas que habitam as ruas nos distritos centrais da cidade. ${ }^{186}$

Quanto ao Censo de 2009, nota-se que o perfil das pessoas analisadas são em sua maioria homens $(79,7 \%)$, negros ou pardos $(63,5 \%)$, adultos $(77,9 \%)^{187}$, nascidos em São Paulo (16,8\%) ou na Grande São Paulo (50\%), alfabetizados (96\%), tendo algum tipo de profissão $(92,4 \%)$, sendo que $20 \%$ das pessoas ainda exerce e $35,9 \%$ deixou de exercer entre 1 e 2 anos. ${ }^{188}$ Do total de pessoas entrevistadas, $67 \%$ tinha algum tipo de profissão. Dentre as principais fontes de renda dessa população, podemos citar, em ordem decrescente, de importância a catação de material reciclável (62,1\%), "flanelinha" (12,9\%), carga e descarga (10,9\%), comércio ambulante (8,5\%), construção civil $(6,9 \%)$ e limpeza e faxina $(1,6 \%)$.

Em 2012, foram publicados os mais recentes estudos sobre o perfil da população de rua na cidade de São Paulo ${ }^{189}$, pesquisa essa realizada por intermédio da Fundação Escola de Sociologia e Política de São Paulo, em parceria com a SMADS/PMSP. Em tal pesquisa, obteve-se o número atualizado de pessoas em situação de rua em São Paulo: 14.478, dentre elas 6.765 em situação de rua e 7.713 em centros de acolhida localizados na capital.

186 Fundação Instituto de Pesquisas Econômicas, 2009, pp. 8-10

187 Brancos representam 28,2\% e pessoas sem identificação, 8,3\%; mulheres representam 15,5\% e pessoas sem identificação, 4,8\%; crianças representam $67 \%$, idosos, $7,7 \%$ e pessoas sem identificação, $7,7 \%$. In: Fundação Instituto de Pesquisas Econômicas, 2009, pp. 12-13.

188 Trajetória de vida da população atendida nos serviços de acolhimento para adultos em situação de rua município de São Paulo. 2010. Centro de Estudos Rurais e Urbanos (CERU). pp.4-6.

189 (i) Prefeitura do Município de São Paulo. Secretaria Municipal de Assistência e Desenvolvimento Social. Núcleo de Pesquisas em Ciência Sociais - FESPSP. Censo da população de rua na cidade de São Paulo. Principais Resultados. (2011); (ii) Prefeitura do Município de São Paulo. Secretaria Municipal de Assistência e Desenvolvimento Social. Núcleo de Pesquisas em Ciência Sociais - FESPSP Caracterização socioeconômica da população em situação de rua de São Paulo. (2011); (iii) Prefeitura do Município de São Paulo. Secretaria Municipal de Assistência e Desenvolvimento Social. Núcleo de Pesquisas em Ciência Sociais - FESPSP. Censo e Caracterização Sócio econômica da população em situação de rua na municipalidade de São Paulo. (2011). 
Constatou-se que houve um crescimento de $4.5 \%$ quanto ao número de pessoas acolhidas em albergues, quando comparado ao censo anterior. ${ }^{190}$

Notou-se também que os distritos centrais ainda continuam concentrando a maior parte da população em situação de rua. ${ }^{191}$

A maioria dos moradores de rua ainda é formada por homens (75.8\%), negros ou pardos $(60.7 \%)$, adultos $(78.3 \%)$, alfabetizados $(86.2 \%)^{192}$ e nascidos no Estado de São Paulo $(51.1 \%){ }^{193}$

Após a realização de entrevistas com uma amostra de 690 pessoas, formada tanto por indivíduos que dormiam em logradouros públicos (não acolhidas) como indivíduos acolhidos, algumas informações importantes foram reveladas.

Primeiramente, o motivo principal para as pessoas terem ido para as ruas decorria de desentendimentos familiares: $37.1 \%$ das pessoas acolhidas e $42 \%$ das pessoas não acolhidas informaram esse motivo. Esses desentendimentos familiares decorriam principalmente de brigas e problemas com álcool e drogas. Outro motivo com grande incidência foram questões econômicas, como demissão de seu trabalho ou despejo por falta de pagamento: $31.6 \%$ dos acolhidos e $21.3 \%$ dos não acolhidos disseram que acabaram nas ruas por esse motivo. ${ }^{194}$

Outra informação importante obtida referiu-se à grande incidência de problemas de saúde e de segurança: $34.6 \%$ dos não albergados e 37.3\% dos não albergados informaram que tiveram problemas de saúde nos últimos 7 meses. Quanto à segurança, nota-se que a incidência de agressões em relação a pessoas não acolhidas é mais alta (52.8\%) quando

190 Prefeitura do Município de São Paulo. Secretaria Municipal de Assistência e Desenvolvimento Social. Núcleo de Pesquisas em Ciência Sociais - FESPSP. Censo da população de rua na cidade de São Paulo. Principais Resultados (2011). p. 6.

191 Na nova pesquisa, houve análise separada dos grupos de pessoas acolhidas e de pessoas que usavam a rua para dormir. Contudo, de forma geral, a região central concentre a maioria das pessoas em situação de rua: $73.8 \%$ das pessoas acolhidas estavam na região central e $64 \%$ das pessoas que usavam a rua para dormir estavam na região central. In: Censo e Caracterização Sócio econômica da população em situação de rua na municipalidade de São Paulo. (2011). P. 28 e 61.

192 Valores decorrentes da análise quantitativa de pessoas não albergadas; $23.9 \%$ das pessoas são do sexo feminino; $36.7 \%$ são pessoas brancas; $12.4 \%$ são idosos e 9.3\% são adolescentes; $13.8 \%$ não eram alfabetizados; In: Caracterização socioeconômica da população em situação de rua de São Paulo. FESPSP. p. 75.

193 Valores referentes a pessoas não albergadas, que utilizavam logradouros público. Dentre essas pessoas, 97.5\% eram brasileiros e sobre esse número deverá ser feito o cálculo baseado no percentual de cada unidade da federação; dentre os 97.5\%, 51.1\% eram originários de São Paulo, $10.4 \%$ da Bahia, $8.1 \%$ de Minas Gerais, 5.5\% de Pernambuco e $4.9 \%$ do Ceará. In: Caracterização socioeconômica da população em situação de rua de São Paulo. FESPSP. (2011). p. 75.

194 Censo e Caracterização Sócio econômica da população em situação de rua na municipalidade de São Paulo. (2011). P. 75-79 e 92-96. 
comparada às pessoas acolhidas (38.5\%). As agressões incluem agressões verbais ou físicas, abusos sexuais, roubos e furtos, ferimentos com facas ou revólver ou jatos d'água. ${ }^{195}$

Por último, no que toca aos trabalho e formas de obtenção de renda: dentre as principais funções exercidas antes de se tornarem moradores de rua, foram elencadas as seguintes profissões: auxiliar de limpeza/serviços gerais/faxineira/doméstica; pedreiros/azulejistas; agentes de venda/representante legal/balconistas; servente/ajudante de obra; segurança, marceneiro/carpinteiro. Nota-se que mesmo em relação aos ofícios anteriores a maioria dos registros referiam-se a ocupações "pauperizadas", apresentando indicadores de alta vulnerabilidade. ${ }^{196}$

Depois de se tornarem moradores de rua, a atividade remunerada mais comumente citada foi a de catador de materiais recicláveis. Também era muito recorrente a menção a atividades de distribuidor de panfletos, ajudante geral/faxineiro, ajudante de pedreiro, chapa e vendedor/camelô. ${ }^{197}$

Nota-se que a maioria das atividades envolvidas são marcadas pela a precarização, pela irregularidade e pelo ganho diminuto. ${ }^{198}$ Em média, na cidade de São Paulo, essas pessoas ganham de $\mathrm{R} \$ 21.49$, o que, calculado com base no ganho até o final do mês, chegaria ao valor de um salário mínimo. ${ }^{199}$ Contudo, é nesse momento em que a irregularidade dos rendimentos pesa: nem sempre é possível se fazer "bicos", encontrar materiais recicláveis ou cargas para descarregar. Essa falta de regularidade, associada aos baixos valores recebidos diariamente, faz com que o trabalho exercido por essas pessoas não se torne uma base segura para a saída das ruas. ${ }^{200}$

195 Censo e Caracterização Sócio econômica da população em situação de rua na municipalidade de São Paulo. (2011). P. 79 e 95.

196 A pesquisa desenvolvida por Sarah Escorel teve por palco a cidade do Rio de Janeiro. Entretanto, pelos registros encontrados pela autora, percebe-se que o perfil profissional do morador do Rio de Janeiro se assemelha aquele encontrado em São Paulo; as profissões mais citadas por moradores de rua cariocas foram as seguintes: serventes de pedreiros ou pedreiros, pintores e caiadores, vigias, guardas e vigias particulares, vendedores ambulantes, borracheiros e montadores elétricos, o que, equivale, em grande parte, às atividades desenvolvidas por moradores de rua na cidade de São Paulo. In: ESCOREL, Sarah. Vidas ao léu: trajetórias de exclusão social. Rio de Janeiro: Editora Fiocruz, 1999. pp. 181-184.

197 Caracterização socioeconômica da população em situação de rua de São Paulo. FESPSP. p. 96.

198 MACHADO, Igor Rolemberg Gois. Violações de direitos humanos e cidadania categorizada: estudo de caso a partir da população em situação de rua do centro de São Paulo. (...) 2011. p. 56.

199 Dentre as pessoas não acolhidas, $84.1 \%$ informou que seus rendimentos decorrem de bicos. Somente $1.8 \%$ tinha carteira assinada, $9.4 \%$ era empregados fixos sem carteira assinada e $4.1 \%$ eram temporários. Dentre as pessoas acolhidas, $16.5 \%$ são empregados com carteira assinada, $6 \%$ são fixos sem carteira assinada, $11 \%$ são temporários e $62 \%$ faz bicos. In: Caracterização socioeconômica da população em situação de rua de São Paulo. FESPSP. p. 82, 96.

200 SNOW, David. A, ANDERSON, Leon. Down on their luck: a study of homeless street people. (...) pp. 
A tabela a seguir indica a evolução do número de pessoas em situação de rua, desde as primeiras contagens realizadas em 1991:

\begin{tabular}{|c|c|c|c|}
\hline Ano & Pop. Rua (total) & Albergados & Logradouros públ. \\
\hline 1991 & 3.852 & 460 & 3.392 \\
\hline 1994 & 4.449 & 1.749 & 2.800 \\
\hline 1996 & 5.334 & 1.913 & 3.421 \\
\hline 1998 & 6.453 & 3.416 & 3.037 \\
\hline 2000 & 8.706 & 3.693 & 5.014 \\
\hline 2003 & 10.394 & 6.186 & 4.208 \\
\hline 2009 & 13.666 & 7.079 & 6.587 \\
\hline 2012 & 14.478 & 7.713 & 6.765 \\
\hline
\end{tabular}

Os censos realizados na cidade de São Paulo possibilitaram se chegar a algumas conclusões: a primeira delas, e a de mais fácil observação, é que o número de pessoas em situação de rua vem aumentando. Além disso, a partir do ano de 2003, pode-se notar o aumento - e a manutenção desse aumento - do número de moradores de rua que utilizam o serviços de albergue. No mais, nota-se a concentração de pessoas na região central sempre foi apontada nas contagens feitas.

Por fim, em relação às entrevistas realizadas, percebe-se que a população em situação de rua se encontra em um estado preocupante de vulnerabilidade: são recorrentes os problemas de saúde, as fragilidades originadas no âmbito familiar, e a constante incidência de denúncias no que toca à violência. A baixa capacidade de inserção no mercado formal de trabalho, associado à irregularidade e a pequenos rendimentos indica as dificuldades econômicas dessa população. Pelo quadro geral apontado, nota-se a complexidade da situação em que se encontram tais pessoas e a necessidade de atenção multifacetada por parte do Estado. 


\subsection{Políticas públicas para a população de rua em São Paulo}

A concretização das políticas públicas voltadas para a População de Rua, principalmente aquelas previstas na LOAS, ocorre, em sua maioria, na esfera municipal, seguindo os marcos legais e constitucionais já citados.

Contudo, antes mesmo da LOAS, o poder público em São Paulo já tinha iniciativas, ainda que tímidas, no sentido de fornecer assistência, por meio do Estado, a pessoas em situação de rua.

Como consequência, tendo em vista se tratar de diferentes formas de atuação por parte do poder público, é possível se notar que a implementação dos serviços públicos voltados à população na cidade de São Paulo pode ser dividida em pelo menos duas fases bem distintas, tendo como referência os governos das prefeitas Luiza Erundina (19891992) e Marta Suplicy (2001-2004). ${ }^{201}$

A eleição de Luiza Erundina para Prefeitura de São Paulo em 1989 foi um marco em termos de tratamento da questão da população de rua. Já no início de sua gestão, em 1990, é assinado um decreto que regulariza o oficio de catadores de materiais recicláveis. Em 1992, ocorre o I Seminário Nacional da População de Rua de São Paulo, que teve por base uma pesquisa encomendada pela Prefeitura para mapear o perfil dos moradores de rua da cidade, e que forneceu dados para orientar a prática de atendimento a essa população.

Nessa época, através da Secretaria Municipal de Bem Estar Social (SEBES), são desenvolvidas as primeiras respostas de atenção à população de rua através da instalação de casas de Convivência, como a Casa de Convivência São Martinho (1990), ligada ao Centro Social Nossa Senhora do Bom Parto e Porto Seguro (1992), ligada à Associação Evangélica Beneficente - AEB. ${ }^{202}$ É também desse período a instalação dos primeiros alojamentos para o período de inverno (Operação Inverno) e dos primeiros albergues em parceria entre a Prefeitura e a sociedade civil: Viaduto Pedroso, ligado à Catedral Metodista de São Paulo, o albergue Lygia Jardim, ligado ao Instituto Lygia Jardim ${ }^{203}$ e a

201 Cf. PONTIFÍCIA UNIVERSIDADE CATÓLICA DE SÃO PAULO. INSTITUTO DE ESTUDOS ESPECIAIS. Cadernos 2. 2004.

202 http://www.aeb-brasil.org.br/; http://bompar.org.br/; PONTIFÍCIA UNIVERSIDADE CATÓLICA DE SÃO PAULO. INSTITUTO DE ESTUDOS ESPECIAIS. Cadernos 2. 2004, pp. 5-6; AMARAL, Denise Perroud. A Rede de Atenção à População em Situação de Rua: possibilidades de interferência na definição e concretização de uma política pública na cidade de São Paulo. (...) pp. 66-68.

203 http://www.metodista.br; http://www.asapam.org.br/Lygia Jardim/; PONTIFÍCIA UNIVERSIDADE CATÓLICA DE SÃO PAULO. INSTITUTO DE ESTUDOS ESPECIAIS. Cadernos 2. 2004, pp. 5-6; AMARAL, Denise Perroud. A Rede de Atenção à População em Situação de Rua: possibilidades de 
Associação dos Voluntários para Integração dos Imigrantes. ${ }^{204}$

Em 1993, retomaram-se dentro da Câmara Municipal de São Paulo as discussões sobre o atendimento à população de rua, tendo por base o documento Proposta de Criação Orçamentária elaborado e aprovado em abril de $1992 .{ }^{205}$ Como decorrência dessa proposta, em 1993, foi elaborado o primeiro projeto de lei para regulamentar os serviços que já eram prestados à população de rua, buscando ainda garantir direitos a essas pessoas no que tocava o atendimento.

Contudo, somente em 1997, por decorrência de pressões políticas e manifestações públicas, o Projeto de Lei é sancionado pelo Prefeito Paulo Maluf e transformado na lei 12.316/97. ${ }^{206}$ É necessário advertir que a política da Assistência Social, como um todo, durante as gestões dos Prefeitos Paulo Maluf e Celso Pitta foi marcada pelo desrespeito à Loas e pelo assistencialismo. ${ }^{207}$

Uma segunda fase de atuação do município no que toca às políticas públicas voltadas para pessoas em situação de rua se inicia com a gestão Marta Suplicy (20012004).

Em 2001, a lei municipal 12.316/1997 foi regulamentada por meio do Decreto 40.232, de 2 de Janeiro de 2001, dispondo, dentre outros pontos, sobre os princípios que regeriam a atuação do poder público e os tipos e as formas pelas quais seriam prestados os serviços. Definia também o padrão de qualidade e a gestão participativa nos programas e serviços a serem desenvolvidos.

Esses diplomas legais estabeleceram como obrigação do poder público municipal a prestação de atendimento à população de rua na Cidade de São Paulo. O poder executivo municipal, por meio da Secretaria da Assistências Social, seria responsável pela implantação e coordenação do Programa de Atenção à População de Rua. Contudo, em que pese se colocasse a Secretaria da Assistência Social como o ente responsável, os dispositivos de lei eram claros ao definir que a ação municipal deveria ser pautada pela interdisciplinaridade e diálogo entre as secretarias (intersetorialidade), de modo a garantir a

interferência na definição e concretização de uma política pública na cidade de São Paulo. (...) Pp. 72-75.

204 SIMÕES JUNIOR. José Geraldo. Moradores de Rua. (...) p.49.

205 ROSA, Cleisa Moreno Maffei. Vidas de rua. São Paulo: Hucitec: Associação Rede Rua: 2005. P. 174.

206 FRANGELLA, Simone Miziara. Corpos errantes urbanos. (...) p. 97.

207 A título de exemplificação, pode-se citar a criação, durante o governo de Paulo Maluf, do Centro de Apoio Social de Atendimento do Município de São Paulo (Casa), presidido, primeiramente, por Silvia Maluf, e depois por Nicéa Pitta, mantendo a lógica do "primeiro-damismo". YASBEK, Maria Carmelita. Assistência Social na cidade de São Paulo: a (difícil) construção do direito. Observatório dos Direitos dos Cidadãos. Instituto Pólis/PUC-SP. Março de 2014. P. 19. 
unidade de atuação. $^{208}$

Uma importante ideia contida na Lei de Atenção à População de Rua é que os tipos de serviço prestados deveriam acompanhar o grau de autonomia dos usuários e as diferentes etapas do processo de reinserção social. Dessa forma, quanto mais autonomia uma pessoa tivesse e quanto mais inserido socialmente se encontrasse, mais distante da rua ele deveria estar, devendo os serviços e programas refletir essa diferença na realidade e vivência dos usuários. Portanto, a lei previa serviços diversificados, acompanhando a heterogeneidade do perfil do morador de rua.

Em 2001, é editada a lei municipal 13.153/2001, posteriormente regulamentada pelo Decreto 43.698/2003. Essa lei surge para disciplinar a política pública da assistência social operada por meio de convênios. A ideia é que os serviços e programas direcionados à população de rua fossem operados através de rede municipal ou por convênios de prestação de serviços com associações civis de assistência social. ${ }^{209}$ Dessa forma, alguns serviços da assistência seriam prestados diretamente pelo poder público, enquanto outros seriam prestados por entidades sociais, através de convênios.

Para regulamentar essas parcerias com a sociedade civil, é editado o Decreto 43.698/2003, prevendo os procedimentos necessários para a celebração de convênios entre a Secretaria de Assistência Social e entidades sem fins lucrativos. ${ }^{210}$ Para tanto, é necessária a publicação de edital no Diário Oficial do Município, convocando associações civis sem fins econômicos para a celebração de parceria. Caso queiram celebrar o convênio, essas entidades deverão entregar uma proposta, referindo-se ao programa ou serviço que lhes interessar. ${ }^{211}$

Para cada serviço ou conjunto de serviços, haverá a convocação de audiência pública específica. Haverá também um Comitê de Avaliação que examinará as propostas das associações tanto em seu conteúdo como em seu formato. Ao final, o Comitê elabora um parecer técnico sobre todas as propostas apresentadas, e escolhe a entidade mais apta

\footnotetext{
208 Artigo $1^{\circ}$, caput e $\S \S 1^{\circ}$ e $2^{\circ}$ do Decreto $40.232 / 2001$.

209 Artigo $2^{\circ}, \S 1^{\circ}$ da lei $12.316 / 1997$.

210 De acordo com os artigos $6^{\circ}$ e $7^{\circ}$ do Decreto 43.698/2003, a Secretaria Municipal de Assistência Social será responsável pela manutenção de um Banco Público de Dados de Organizações e de Serviços de Assistência Social da Cidade de São Paulo, mediante o cadastramento de dados das associações e organizações de assistência social. Esse banco de dados sempre estará aberto a novas inscrições, assim como ficará disponível para consultas públicas. O cadastramento é condição para a concessão de matrícula e de credenciamento. Por sua vez, A matrícula e o credenciamento são condições de préqualificação das associações e organizações para realizar convênios com o Município de São Paulo

211 Artigos 10 e 11 do Decreto 43.698/2003. O artigo 12 do Decreto descreve os documentos e requisitos que deverão constar nas propostas das associações que objetivam celebrar convênios com a Prefeitura.
} 
para executar o serviço. O parecer do Comitê de Avaliação deverá ser publicado no Diário Oficial do Município. ${ }^{212}$ De posse do parecer do Comitê de Avaliação, o Supervisor Regional de Assistência Social emitirá parecer conclusivo indicando a associação ou organização mais apta para celebrar o convênio. Após a homologação pela Secretária Municipal de Assistência Social, a decisão é novamente publicada no Diário Oficial do Município. $^{213}$

Dessa forma, ao início da gestão da Prefeita Marta Suplicy, foram editadas uma série de normas de forma a regulamentar e formalizar tanto a prestação dos serviços na área da assistência social, de forma geral (como pode se observar pela lei municipal 13.153/2001 e pelo Decreto 43.698/2003) como especificamente para a população em situação de rua (através do Decreto 40.232/ 2001).

Após criar o arcabouço jurídico necessário à implantação dos serviços voltados para a população em situação de rua, o poder executivo passou a construir o arcabouço ideológico que embasaria essa política pública municipal. Nesse sentido, a Prefeitura de São Paulo, por intermédio da Secretaria Municipal de Assistência Social, constituiu juntamente do Fórum das Entidades Sociais de atenção à população de rua o Programa Acolher: Reconstruindo Vidas, que demarcou as características dos serviços voltados à população de rua a partir daquele momento. ${ }^{214}$ Trataremos especificamente do Programa Acolher mais a frente, ao realizar o estudo de caso.

Nesse período, também é instalado o Conselho de Monitoramento da Política de Atenção à População em Situação de Rua, composto por usuários, empresários, representantes de organizações sociais e de órgãos do governo (Secretarias da Saúde, Trabalho e Assistência Social). ${ }^{215}$ Esse Conselho, com reuniões mensais, discutia os problemas e dificuldades na implementação da Lei de Atenção à População em Situação de Rua, buscando soluções e alternativas aos serviços criados.

Nessa época, a Fundação Instituto de Pesquisas Econômicas (FIPE) elabora, em 2000 e 2003, as duas primeiras pesquisas censitárias referentes à população em situação de rua na cidade de São Paulo, como já mencionado acima.

212 Artigos 13 e 14 do Decreto 43.698/2003.

213 Artigos 16 a 18 do Decreto 43.698/2003.

214 PONTIFÍCIA UNIVERSIDADE CATÓLICA DE SÃO PAULO. INSTITUTO DE ESTUDOS ESPECIAIS. Cadernos 2. 2004, p. 6

215 Instituído por meio do Decreto $\mathrm{n}^{\circ}$ 43.277, de 29 de maio de 2003, em consonância com o disposto no artigo $5^{\circ}$ da Lei $n^{\circ} 12.316$, de 16 de abril de 1997, e no artigo $7^{\circ}$ do Decreto ${ }^{\circ} 40.232$, de 2 de janeiro de 2001. O Decreto 43.277 foi revogado pelo Decreto ${ }^{\circ} 53.795$, de 25 de março de 2013, que instituiu o Comitê Intersetorial da Política Municipal para a População em Situação de Rua - Comitê Poprua. 
Na gestão da Prefeita Marta também é criada a Central de Atendimento Permanente e de Emergência (CAPE). A CAPE funciona como um plantão 24 horas, por meio da atuação de uma equipe de campo, e que tem por objetivo responder a solicitações de encaminhamento - feitas pelos próprios usuários ou por terceiros - aos serviços disponíveis no município. Para isso, na época, existiam 170 educadores responsáveis pela abordagem nas ruas, identificando pontos de concentração de pessoas em situação de rua, e direcionando-as para o atendimento adequado.

Em 2004, é criado o SisRua, um sistema de registro de dados da Secretaria de Assistência Social, que centraliza informações sobre os moradores de rua atendidos em albergues e abrigos especiais da rede conveniada com a Prefeitura. São os próprios albergues e abrigos que adicionam as informações no sistema, e mantêm o registro diário dos dois tipos de abrigamento: ${ }^{216}$ usuários cadastrados nos albergues (vaga fixa) e moradores que têm vaga para pernoite. ${ }^{217}$ De 2002 a 2005, mais de 23 mil pessoas já haviam sido cadastradas no banco de dados do SisRua. ${ }^{218}$

Os serviços voltados à população de rua expandiram muito desde 2001. Ao final da gestão Marta Suplicy, em 2004, registrou-se que a Secretaria Municipal de Assistência Social, através de convênios com entidades, mantinha 26 albergues, com vagas para 4.438 pessoas; 9 abrigos especiais para 535 pessoas; 17 Centros de Convivência para 1.797 pessoas; 9 Núcleos de Incentivo à Economia Solidária para 920 pessoas e 40 unidades de Moradia Provisória com atendimento a 337 pessoas. ${ }^{219}$

Nos anos que se seguiram a 2004, pode se delinear a formação de uma terceira fase no que toca as iniciativas voltadas à população em situação de rua.

Após a saída da prefeita Marta Suplicy, foi eleito o Prefeito José Serra (01\%/01/2005 -31/03/2006), posteriormente substituído por seu vice-prefeito, Gilberto Kassab (31/03/2006-01\%01/2013). No lugar da Secretaria Aldaíza Sposati, Floriano Pesaro assumiu como Secretário da Assistência Social.

${ }^{216}$ Os tipos de vaga disponíveis em albergues variam de acordo com o tempo de permanência, se diferenciando, portanto, em vagas fixas e pernoite. Quando o usuário consegue vaga fixa, ele tem a garantia de que, pelo menos por alguns meses, terá um lugar para dormir e para comer. A vaga de pernoite, por sua vez, é marcada pela instabilidade, pois refere-se somente a uma noite. O usuário, para tentar conseguir uma vaga, deverá chegar cedo no albergue, e aguardar. Em geral, o usuário consegue a vaga de pernoite, mas esse sistema faz com que a pessoa perca boa parte de seu dia esperando.

217 PONTIFÍCIA UNIVERSIDADE CATÓLICA DE SÃO PAULO. INSTITUTO DE ESTUDOS ESPECIAIS. Cadernos 2. 2004, p. 66-68.

218 Secretaria vai expandir rede de proteção social à população de rua. Diário Oficial da Cidade de São Paulo, 30 de abril de 2005, p. II

219 ROSA, Cleisa Moreno Maffei. Vidas de rua. São Paulo: (...) pp. 176-177. 
Em abril de 2005, a rede de atendimento voltada à população de rua contava com 9 albergues noturnos (1360 vagas), 17 albergues com núcleo de serviços 24 horas (4.968 vagas), 9 abrigos especiais (565 vagas), 11 casas de convivência ou Núcleo de Serviço de Convivência (1897), 8 Núcleos de Qualificação e Capacitação Profissional (1140 vagas), 11 moradias provisórias (353) e 1 bagageiro (228 boxes). Os 26 albergues da rede tinham capacidade para atender 6.328 e, na época, estavam com vagas 6.180 ocupadas. ${ }^{220}$

O Programa iniciado na gestão da Prefeita Marta Suplicy, Programa Acolher: Reconstruindo vidas, teve continuidade por meio do Programa São Paulo Protege dividido em dois subprogramas, um voltado à proteção adulta e outro à proteção da crianças. ${ }^{221} \mathrm{O}$ objetivo do programa era, inicialmente, aumentar o número de serviços conveniados, sempre vinculando-os à Secretaria de Assistência Social. ${ }^{222}$ Floriano Pesaro afirmava se tratar de um programa intersetorial, com foco não somente na assistência, mas sim buscando uma integração com as demais secretarias (saúde, trabalho e habitação) ${ }^{223}$.

No início de 2005, a Secretaria de Assistência e Desenvolvimento Social ${ }^{224}$ tinha 780 convênios celebrados. Pesaro entendia que os convênios teriam de ser repensados, pois eram caros e não prestavam serviços de qualidade. Dessa forma, indicou que provavelmente seriam feitos cortes de gastos. ${ }^{225}$

As primeiras medidas tomadas por Floriano ocorreram em relação ao tamanho dos hipercomplexos localizados embaixo de viadutos: Albergue Pedroso (380 vagas), albergue São Francisco (650 vagas) e Albergue Cirineu (374 vagas) ${ }^{226}$. A intenção era de progressivamente desativar esses equipamentos, inicialmente realocando parte dos

220 Secretaria vai expandir a rede de proteção social à população de rua. Diário Oficial da Cidade de São Paulo, de 30 de abril de 2005. P. II.

221 PESARO, Floriano. O Futuro no presente. Por uma São Paulo mais humana e participativa. Editora Gente. São Paulo, 2008. P. 82-83.

222 Pode-se atribuir essa continuidade na gestão a dois motivos: um deles é a edição da Lei de Atenção à População em Situação de Rua que, ao regulamentar as diretrizes e serviços a serem prestados, dificultou possíveis mudanças bruscas na gestão da política assistencial. Outro aspecto levantado deveu-se à ligação acadêmica entre a ex-Secretária, Aldaíza Sposati, e o novo Secretário, Floriano Pesaro, pois fora mencionado por funcionários na época que Aldaiza teria sido professora de Floriano. Dessa forma, a continuidade nos trabalhos teria se devido à consideração de que Floriano teria visto nas práticas de Aldaíza um trabalho de qualidade. Cf. COSTA, Daniel Lucca Reis da. A rua em movimento. P.188.

223 PESARO, Floriano. O Futuro no presente. Por uma São Paulo mais humana e participativa. (...) pp. 184.

224 No início da gestão Serra-Kassab, houve alteração de nomenclatura: de Secretaria da Assistência Social passou para o nome Secretaria de Assistência e Desenvolvimento Social.

225 Queremos esse povo trabalhando com dignidade. O Trecheiro, Fevereiro de 2005. p. 4.

226 De 2008 a 2010, os albergues Cirineu e São Francisco foram fechados, o que resultou em 700 leitos a menos na região central de São Paulo. In: Kassab fecha albergues e lota as ruas. Folha de São Paulo. 04 de fevereiro de 2010. 
usuários, para no futuro, se abrir novos albergues no centro, com menor capacidade. ${ }^{227}$

Em agosto de 2005, a SMADS anunciou o projeto de expansão da rede assistencial para bairros que ainda não tinham estrutura organizada, pois se partiu da constatação de que o centro concentrava a maior parte de serviços e também de pessoas em situação de rua. Entendia-se que a maior parte das pessoas em situação de rua não eram originárias do centro e sim da periferia. Dessa forma, buscou-se a abertura de novos equipamentos fora da região central, nas regiões de Aricanduva, Santo Amaro, São Mateus, Ermelino Matarazzo e São Miguel. ${ }^{228}$

Desde o início da gestão Serra-Kassab, novos serviços foram criados e a rede de atenção à população de rua se expandiu. Dentre os novos serviços criados, os mais relevantes foram o Espaço de Convivência - Tenda, o Centro de Referência Especializado para a População de Rua, o CREAS POP e o Complexo Prates.

A primeira tenda foi criada em julho de 2009, Espaço de Convivência Jardim da Vida Dom Luciano Mendes de Almeida I, no Parque Dom Pedro, região central da cidade. As tendas foram idealizadas como uma forma de suprir o atendimento durante o dia à população em situação de rua, além de funcionar como serviço intermediário entre a rua e os centros de acolhidas. A tenda era vista como um espaço em que os moradores de rua "têm acesso a direitos básicos, com regras mais flexíveis, e o principal, um maior contato com educadores e assistentes sociais, o que aumenta neles a ideia de reestruturar suas vidas". A segunda tenda, Espaço da Vida II, foi inaugurado em fevereiro de $2010 .{ }^{229}$ Até meados de 2013, a cidade contava com 9 tendas.

Em outubro de 2010, foi inaugurado o primeiro Centro de Referência Especializado para a População em Situação de Rua - CREAS POP - na região da Bela Vista. O CREAS POP pretendia ser "uma experiência inovadora na área da assistência social da Capital por ter seu serviço direcionado exclusivamente para pessoas em situação de rua. Além de auxiliar na obtenção de documentos, os usuários podem contar com capacitação profissional, inclusão no mercado de trabalho e orientação jurídica”. A iniciativa de criação do CREAS-POP fazia parte das diretrizes do Ministério do Desenvolvimento

227 PESARO, Floriano. O Futuro no presente. Por uma São Paulo mais humana e participativa. (...) pp. 186.

228 PESARO, Floriano. O Futuro no presente. Por uma São Paulo mais humana e participativa. (...) pp 191192.

229 Espaço de Convivência Jardim da Vida completa um ano, com 71 mil atendimentos. Diário Oficial Cidade de São Paulo, de 3 de agosto de 2010. 
Social e Combate à Fome. ${ }^{230}$

Em julho de 2011, foi criado o Segundo Centro Especializado, no Complexo Boracea. $^{231}$

Por sua vez, em março de 2012, foi inaugurado o Complexo Prates, o primeiro equipamento a reunir ações integradas entre a Saúde Pública e a Assistência Social voltado ao tratamento e a recuperação de dependentes químicos em situação de rua e vulnerabilidade social na região central da cidade de São Paulo. O Complexo Prates, em sua inauguração, contava com um Espaço de Convivência para adultos, com capacidade para 1.200 pessoas, um Serviço de Acolhimento Institucional para crianças e adolescentes, com 20 vagas, e um Centro de Acolhida para adultos, com 120 leitos. Ademais, a Secretaria Municipal de Saúde disponibiliza no local uma unidade de Assistência Medica Ambulatorial (AMA) e um Centro de Atenção Psicossocial Álcool e Drogas (CAPS AD), com 11 leitos para observação e internação e capacidade para atendimento de 300 pacientes por dia, em acompanhamento. A proposta da Secretaria Municipal de Saúde era acolher o usuário e facilitar a adesão ao tratamento de saúde e da dependência química. ${ }^{232}$

Abaixo, pode-se observar a evolução dos serviços voltados à população em situação de rua, no que toca à rede conveniada, com os números relativos aos anos de 2008, 2012 e 2013. Pode se notar claramente o aumento dos serviços de acolhida (Centro de Acolhida 16 horas, de Centro de Acolhida 24 horas e Centro de Acolhida Especial), que aumentaram de 38, em 2008, para 50, em 2013, enquanto os serviços de República e Núcleo de Serviço e Convivência/Inserção Produtiva e Capacitação mantiveram os mesmos números entre 2008 e 2013: 6 e 11, respectivamente.

${ }^{230}$ Prefeito inaugura $1^{\circ}$ Centro de Referência Especializado para População em Situação de Rua. http://www.prefeitura.sp.gov.br/cidade/secretarias/subprefeituras/se/noticias/?p=15572.

231 Prefeitura abre dois novos equipamentos voltados à população em situação de rua. Diário Oficial Cidade de São Paulo, 6 de julho de 2011. P. I.

232 Prefeito inaugura Complexo Prates para trabalho integrado de combate às drogas. Diário Oficial Cidade de São Paulo, de 28 de março de 2012. 


\begin{tabular}{|c|c|c|c|c|c|c|}
\hline \multirow{2}{*}{ Tipos de serviço - Rede Conveniada } & \multicolumn{2}{|c|}{ Dezembro de 2008} & \multicolumn{2}{|c|}{ Dezembro de 2012} & \multicolumn{2}{|c|}{ Abril de 2013} \\
\hline & $\mathrm{N}^{\circ}$ & Capac. & $\mathrm{N}^{\mathrm{o}}$ & Capac. & $\mathrm{N}^{\mathrm{o}}$ & Capac. \\
\hline $\begin{array}{l}\text { Centro de Acolhida para pessoas em situação de } \\
\text { rua (16h/24h e Reins. Social) }\end{array}$ & 28 & 6.657 & 34 & 7.448 & 35 & 7.578 \\
\hline $\begin{array}{l}\text { Centro de Acolhida Especial (Mulheres, idosos, } \\
\text { famílias, convalescentes, catadores) }\end{array}$ & 10 & 848 & 15 & 1.434 & 15 & 1.434 \\
\hline $\begin{array}{l}\text { Núcleo de Serviço e Convivência/Inserção } \\
\text { Produtiva e Capacitação }\end{array}$ & 11 & 1.972 & 11 & 2.122 & 11 & 2.092 \\
\hline $\begin{array}{l}\text { República para homens/mulheres em situação de } \\
\text { rua }\end{array}$ & 6 & 302 & 6 & 190 & 6 & 190 \\
\hline $\begin{array}{l}\text { Espaço de Convivência para cças, adol. e adultos } \\
\text { em situação de rua - TENDA }\end{array}$ & & & 11 & 2.350 & 9 & 2.100 \\
\hline Bagageiro & 1 & 228 & 1 & 272 & 1 & 272 \\
\hline Abordagem Social de Rua & 12 & 2.850 & 24 & 10.240 & 22 & 8.490 \\
\hline $\begin{array}{l}\text { Oficina Boracea (C. Acolhida } 24 \text { horas/C. } \\
\text { Acolhida Especial para Idosos em situação de } \\
\text { rua/ lavanderia Social e Restaurante) }\end{array}$ & 1 & 380 & 1 & 380 & & 380 \\
\hline Projeto Especial Complexo Prates & & & 1 & 410 & 1 & 410 \\
\hline Subtotal & 69 & 13.237 & 104 & 24.846 & 101 & 22.946 \\
\hline
\end{tabular}

Fonte: Comitê Permanente de Avaliação de Projetos de Pesquisa e Formação/SMADS. 2013.

Por fim, não se pode deixar de citar a edição da Política Nacional para Inclusão Social da População de Rua por meio do Decreto 7.053, de 23 de dezembro de 2009, ${ }^{233}$ que representou um março em termos de institucionalização de diretivas nacionais sobre a política social a ser implementada em relação a essa população. O Decreto 7.053/2009 previa a necessidade de assinatura de um termo de adesão por parte da cada cidade interessada em aderir à política nacional. Na cidade de São Paulo, o termo de adesão foi assinado em 28 maio de $2013^{234}$ pelo recém eleito Prefeito, Fernando Haddad. ${ }^{235}$

${ }^{233}$ Para uma análise detalhada da construção da Política Nacional para Inclusão da População de Rua, ver FERRO, Maria Carolina Tiraboschi. Desafío de la participación social: alcances y límites de la construcción de la Polítca Nacional para la Población en Situación de Calle en Brasil. Dissertação de Mestrado em Ciência Política e Sociológica. Área de Estudos Políticos. Facultad Latinoamericana de Ciencias Sociales. Ano de obtenção: 2012.

234 Política Nacional para a população em situação de rua será implantada na cidade. http://www.prefeitura.sp.gov.br/cidade/secretarias/comunicacao/noticias/?p=148981.

235 Houve ainda a criação de um Comitê - "Comitê PopRua" - criado por meio de um ato público realizado no dia 23 de março, no Salão Nobre da Faculdade de Direito da USP, no Largo São Francisco. Tal comitê tem composição paritária entre governo e sociedade civil, com representantes das Secretarias Municipais de Direitos Humanos e Cidadania, Assistência e Desenvolvimento Social, Saúde, Trabalho e Emprego, 
Pela exposição acima realizada, pode-se notar que a partir da edição de sucessivos diplomas legislativos, em âmbito municipal, que buscavam institucionalizar e regulamentar a atuação do poder público no que toca às pessoas em situação de rua, foi possível a construção efetiva de serviços públicos voltados a essa população. Criou-se, portanto, uma política pública focada especificamente a essas pessoas.

Com o passar dos anos e com as sucessivas gestões municipais, percebeu-se também que a rede de serviços voltados à população em situação de rua vem crescendo e se tornando mais complexa, com a criação de novos programas e tipos de serviços.

\subsection{Relação dos Serviços Previstos e Tipificados}

Buscaremos analisar nesse item os serviços públicos disponíveis à população em situação de rua.

Tanto a Lei ${ }^{\circ}$ 12.316/1997 como o Decreto $n^{\circ} 40.232 / 2001$ descrevem os serviços especificamente voltados à população em situação de rua. No artigo $5^{\circ}$ do Decreto 40.232, esses serviços são elencados e descritos, como se depreende a seguir:

I - Abrigos Emergenciais: constituídos por instalações físicas adequadas mantidos por SAS, diretamente ou em parceria com organizações sociais, equipados com recursos humanos e materiais necessários para acolhida e pernoite, no período de inverno, da população de rua, fornecendo condições de higiene pessoal, alimentação, vestuário, guarda de volumes, trabalho sócio-educativo e acesso aos serviços de referência na Cidade;

II - Albergues/Abrigos Especiais: constituídos por instalações físicas adequadas, equipados com recursos humanos e materiais necessários à acolhida e alojamento de até 100 (cem) pessoas por unidade, operacionalizados diretamente ou em parceria com organizações sociais, com funcionamento permanente, fornecendo condições de pernoite, higiene pessoal, lavagem e secagem de roupas, alimentação, guardavolumes, trabalho sócio-educativo e serviços de documentação e referência na Cidade, destinados a:

a) pessoas em tratamento de saúde;

b) imigrantes recém-chegados;

c) pessoas em situação de despejo ou em dasabrigo emergencial;

d) mulheres vítimas de violência;

Habitação, Educação, Serviços, Coordenação de Subprefeituras e Segurança Urbana. O Comitê Intersetorial da Política Municipal para a População em Situação de Rua - Comitê Poprua foi instituído pelo Decreto $n^{o}$ 53.795, de 25 de março de 2013, que revogou o Decreto 43.277 de 29 de maio de 2003. In: Prefeitura assina termo de adesão à Política Nacional para a População em Situação de Rua. http://www.prefeitura.sp.gov.br/cidade/secretarias/comunicacao/noticias/?p=148874. 
e) mulheres com crianças.

III - Centros de Serviços: constituídos por instalações físicas operadas pela SAS com auxílio da Secretaria Municipal de Saúde, com funcionamento diário, operacionalizados diretamente ou em parceria com organizações sociais, com oferta de locais equipados com recursos humanos e materiais para oferecer, à população de rua, durante o dia, alimentação, condições de higiene pessoal, lavagem e secagem de roupas, guarda de pertences e serviços de referência na cidade;

IV - Restaurantes Comunitários: serviço coordenado pela SAS, envolvendo a participação de SEMAB, operado diretamente ou em parceria com organizações afins, com provisão de instalações situadas em locais centrais para oferta diária de alimentos à população, garantindo padrões nutricionais adequados, por valor que não exceda o preço de custo de cada refeição;

V - Casas de Convivência: operadas diretamente ou em parceria com organizações sociais e empresas, com oferta de espaços dotados de recursos humanos e materiais para promoção de trabalho sócio-educativo em regime de atendimento diário, desenvolvendo atividades de convivência, socialização e organização grupal, atividades ocupacionais, educacionais, culturais e de lazer, assim como oferecendo condições de higiene pessoal, lavagem e secagem de roupas, alimentação, guarda de volumes, serviços de documentação e referência na cidade;

VI - Moradias Provisórias: serviço realizado em conjunto por SEHAB e SAS, operado diretamente ou em parceria com organizações sociais e empresas, com provisão de instalações, próprias ou locadas, com capacidade de uso temporário por até 15 pessoas moradoras de rua e em processo de reinserção social, funcionando em regime de co-gestão. O acesso à moradia provisória estará subordinado a avaliação sócioeducativa do estágio de reinserção social do interessado, realizada pelos albergues e casas de convivência da rede. Manutenção através de contrato de vagas em pensões e congeneres por tempo determinado. A operacionalização desses serviços envolverá responsabilidades compartilhadas, assim discriminadas: ao Poder Público caberá prover e manter as instalações físicas, envolvendo adaptações, reformas e pagamento de tarifas públicas, bem como estabelecer parceria para pagamento de pessoal; às organizações sociais e empresas caberá garantir padrões adequados de qualidade do atendimento bem como participar da gestão compartilhada.

VII - Soluções Habitacionais Definitivas: sob responsabilidade da SEHAB, com oferta de alternativas habitacionais que atendam pessoas em processo de reinserção social e incluam auxílio moradia, locação social e financiamento de construções em regime de mutirão. A provisão desse serviço levará em conta as necessidades e características diferenciadas da população a ser atendida, observando-se, nos casos de idosos e pessoas portadoras de deficiência, o disposto na legislação pertinente;

VIII - Oficinas, Cooperativas de Trabalho e Comunidades Produtivas: consistentes na provisão de programas com a área municipal 
gestora da economia social que, juntamente com SAS, ofertarão instalações preparadas com equipamentos, recursos humanos e materiais para resgate da cidadania através dos direitos básicos de trabalho e capacitação profissional; encaminhamento a empregos, formação de associações e cooperativas de produção e geração de renda e manutenção de projetos agrícolas de desenvolvimento auto-sustentado, que promovam a autonomia e a reinserção social da população de rua;

IX - Programas Integrados e Projetos Sociais: consistentes na implantação e manutenção de programas assistenciais e preventivos realizados nas ruas, por educadores capacitados, com pedagogia própria aplicável ao trabalho com este segmento da sociedade. O programa contará com a cooperação da Guarda Civil de São Paulo e a ação de voluntários e de organizações sociais.

Pelos serviços acima elencados, percebe-se que a legislação municipal buscou contemplar a grande heterogeneidade de demandas e perfis de usuários existentes na cidade de São Paulo. Dessa forma, para as necessidades básicas do dia-a-dia, como alimentação, pernoite e higiene, foram previstos serviços mais simples, como albergues/abrigos, centros de serviços e restaurantes comunitários. Contudo, para aqueles os usuários que já haviam conquistados autonomia, ou já se encontravam em processo de inserção social, foram previstos serviços mais audaciosos, como centros de capacitação profissional, moradias provisórias e soluções de moradia definitiva.

Ademais, a rede assistencial de serviços voltados à população em situação de rua buscava ser completa. A intenção que o poder público atuasse desde abordagens educativas e preventivas nas ruas (nas quais os usuários poderiam ser encaminhados para outros serviços), passando pelo processo de reinserção social, até se chegar à total autonomia.

Em 2010, com o intuito de atualizar o rol de serviços da rede conveniada, assim como atualizar a nomenclatura utilizada, a SMADS editou a Portaria 46/SMADS/2010, estabelecendo e descrevendo os serviços no âmbito assistencial a serem prestados no município. A Portaria 46/SMADS/2010 detalha os serviços previstos na Tipificação Nacional de Serviços Socioassistenciais aprovada por meio da Resolução 109 de 2009 do Conselho Nacional da Assistência Social, mas também inova, criando novas modalidade de serviços a serem prestados em âmbito municipal.

Como já descrito anteriormente, e seguindo as diretivas da LOAS e da NOB/SUAS, os serviços da assistência são prestados pela rede estatal e pela rede conveniada. A rede estatal de serviços voltada especificamente à população de rua, a ser prestada diretamente pela SMADS, constitui-se pelo CRAS, CREAS, Hospedagem para pessoas em situação de 
rua $^{236}$ e CAPE.

Já os serviços conveniados, baseados na Tipificação Nacional de Serviços Socioassistenciais, e que são aplicáveis a adultos em situação de rua, seguem abaixo. ${ }^{237}$

No que toca à Rede de Proteção Especial (Média Complexidade), são previstos dois serviços:

I. Núcleo de Convivência para Adultos em Situação de Rua: tem como finalidade assegurar o atendimento à população em situação de rua e desenvolver atividades direcionadas à reinserção social, construção de vínculos familiares e interpessoais, que permitam a saída da rua. Realiza a escuta dos usuários e desenvolve atividades, como rodas de conversa, oficinas de artesanato e palestras, de acordo com as diretivas dos psicólogos e atendentes sociais presentes no núcleo. São dadas orientações e feitos encaminhamentos para serviços assistenciais ou de outras áreas. $\mathrm{O}$ atendimento é diurno, com duração de 8 horas. O acesso a esse serviço ocorre por meio de procura espontânea do usuário, por encaminhamento decorrente dos serviços de abordagem ou da CAPE, ou mesmo pelo encaminhamento do CREAS ou CRAS.

\section{Serviço Especializado de Abordagem Social às Pessoas em Situação de Rua,} encontra-se referenciado ao CREAS, e tem a finalidade de busca ativa e abordagem de pessoas na ruas, dentre elas crianças, adolescentes e adultos, em quaisquer logradouros públicos onde se identifique pessoas em situação de rua, para posterior encaminhamento para serviços sócio assistenciais. O serviço de abordagem subdividese de acordo com a categoria de pessoas a ser abordada (crianças/adolescentes ou adultos).

a) Serviço Especializado de Abordagem de Adultos em Situação de Rua: voltado especificamente para adultos, idosos e famílias em situação de rua. O funcionamento é diário, entre $8 \mathrm{~h}$ e $22 \mathrm{~h}$, e o acesso se dá através da identificação da própria equipe de abordagem, que encontra um usuário potencial da rede e a partir daí, tenta encaminhá-lo para algum dos serviços disponíveis.

${ }^{236}$ O Serviço de Hospedagem consiste no oferecimento vagas em hotéis ou pensões, por um período de até 3 meses, para pessoas com mais de 18 anos em situação de rua. Trata-se de um serviço voltados para pessoas que já estão em processo de reinserção social, com autonomia financeira e capacidade de gestão cotidiana de suas vidas.

237 A rede municipal de serviços sócio assistenciais inclui uma série de serviços não aplicados à população em situação de rua. Portanto, só foram citados aqui os serviços específicos voltados para essa população. A lista completa de todos os serviços assistenciais se encontra na Portaria 46/2010/SMADS, disponível no site da Prefeitura da Cidade de São Paulo. 
b) Serviço de Apoio à Solicitação de Atendimento à Pessoa em Situação de Rua e Apoio à Emergência: promove a abordagem de pessoas em situação de rua quando a solicitação parte dos munícipes. Ademais, dá apoio à CAPE, em situações de calamidade pública e emergência. Seu funcionamento é ininterrupto. Pode ser acessado por meio do telefone da central atendimento da CAPE ou pelo serviço de atendimento ao cidadão.

No que toca à Rede de Proteção Especial (Alta Complexidade), são previstos três serviços:

I. Centro de Acolhida às Pessoas em Situação de Rua: serviço voltado para o acolhimento provisório para pernoite de pessoas em situação de rua, a partir dos 18 anos, ou de grupo familiar, com ou sem crianças. São oferecidos alimentação, pernoite, instalações sanitárias, locais para banho e higiene pessoal e lavanderia. Há também a realização de atendimento pessoal de profissionais como psicólogos e assistentes sociais. A forma de acesso se dá pelo CRAS, CREAS, CAPE, demais órgãos assistenciais e de proteção humana, além da procura voluntária.

a) Centro de Acolhida para Adultos I por 16 horas: centro de acolhida com funcionamento é ininterrupto, de domingo a domingo, mas somente entre $16 \mathrm{~h}$ e $8 \mathrm{~h}$.

b) Centro de Acolhida para Adultos II por 24 horas diferencia-se do Centro de Acolhida I por se tratar de serviço voltado para atender preferencialmente usuários que estiverem em condições de maior fragilidade e vulnerabilidade pessoa e social. Ademais, o atendimento realizado é ininterrupto, de domingo a domingo, 24 horas por dia.

II. Centro de Acolhida Especial: subdivisão dentre os centros de acolhida; é voltado para priorizar grupos específicos que requerem atendimento diferenciado, de acordo com ciclo de vida, gênero, período de convalescença e família. Há 4 tipos diferentes de Centro de Acolhida Especial: Centro de Acolhida Especial para Idosos; Centro de Acolhida Especial para Mulheres; Centro de Acolhida Especial para Pessoas em Período de Convalescença que necessitem cuidados de saúde; Centro de Acolhida para Famílias.

III.República: unidade de acolhida com característica residencial, na qual é desenvolvido sistema de co-gestão, voltada para jovens, adultos e idosos, possibilitando gradual desenvolvimento de autonomia e independência dos moradores. Há supervisão técnica 
para a gestão coletiva da moradia e apoio para a construção das regras coletivas de convivência, atribuição das atividades domésticas cotidiana e gestão de gastos. $\mathrm{O}$ tempo de permanência é de 6 meses, prorrogáveis por mais 6 meses. É dividido em três tipos de Repúblicas: República para Jovens (18 a 21 anos); República para Adultos; República para Idosos.

Ademais, como já afirmado acima, no município de São Paulo, a Portaria 46/SMADS/2010 também previu serviços complementares, ou seja, serviços conveniados que não se encontram previstos na Tipificação Nacional de Serviços Socioassistenciais, mas que também fazem parte da rede socioassistencial do município, atendendo usuários em situação de vulnerabilidade. Destacamos os serviços prestados para a população em situação de rua, como segue abaixo.

No que toca à Rede de Proteção Especial (Média Complexidade) são previstos quatro serviços:

I. Centro de Capacitação Técnica para Adultos em Situação de Rua. Objetiva desenvolver cursos de formação e de capacitação profissional para a população em situação de rua, contribuindo para o aumento de chances de empregabilidade, desenvolver autonomia e inserção social. É voltado especificamente para a população em situação de rua, mas pode se estender para outros segmentos de vulnerabilidade social.

II. Serviço de Inclusão Social e Produtiva, focado no investimento econômico e social de grupos populares, com iniciativas de capacitação para garantir meio de desenvolvimento de capacidades produtivas e de gestão. Busca a concretização de projetos de vida que permitam a inserção no mundo do trabalho e levem à autonomia. Voltado para pessoas adultas em situação de rua e catadores de materiais recicláveis.

III.Espaço de Convivência para Adultos em Situação de Rua - Tenda. As tendas foram idealizadas como uma forma de suprir o atendimento durante o dia à população em situação de rua, além de funcionar como serviço intermediário entre a rua e os centros de acolhidas. São realizados atendimentos, encaminhamentos e oficinas, mas não há fornecimento de refeições, nem a possibilidade de lavagem e secagem de roupa. $\mathrm{O}$ atendimento é diurno, e pode ser acessado por procura voluntária ou pelo CAPE.

IV. Núcleo de Convivência com Restaurante Comunitário para Adultos em Situação de Rua: serve refeições e realiza atividades de desenvolvimento pessoal e social. 
V. Bagageiro: garante a guarda provisória de pertences e fornece atendimento social para inserção da rede assistencial. Tempo máximo de utilização do bagageiro é de 3 meses, prorrogável por mais 1 mês.

No que toca à Rede de Proteção Especial (Alta Complexidade), são previstos três serviços:

I. Centro de Acolhida para Catadores: acolhimento de indivíduos ou grupo familiar em situação de rua que tenha como meio de vida a catação de materiais recicláveis. O sistema de acolhimento baseia-se na co-gestão com os usuários nas atividades do cotidiano, assim como na formulação das regras de convívio. O serviço deverá oferecer espaço para a acomodação de carroças e cachorro.

II. Complexo de Serviço à População em Situação de Rua - Boracea: conjunto de serviços para o atendimento à população em situação de rua adulta, para ambos os sexos, acompanhado ou não de filhos. O funcionamento é ininterrupto, e há acesso à lavanderia e à cozinha.

III.Complexo de Serviço à População em Situação de Rua - Arsenal da Esperança: acolhimento provisório para homens adultos, em situação de rua. Oferece capacitação profissional e tem funcionamento ininterrupto.

Após a atualização da rede de serviços, em decorrência do disposto na Portaria 46/SMADS/2010, nota-se que foi mantida a diversidade de serviços que vinham previstos pela Lei $\mathrm{n}^{\circ} 12.316$ e pelo Decreto $\mathrm{n}^{\circ} 40.232$.

Dessa forma, a Portaria 46/SMADS/2010 elencou uma série de serviços com o objetivo atuar da forma mais completa possível sobre a heterogênea situação em que se encontram as pessoas em situação de rua. Tanto os serviços prestados diretamente pelo poder público, como aqueles prestados pelas organizações sem fins lucrativos (rede conveniada), buscam atuar desde o momento em que a pessoa se encontra na rua até sua reinserção social, acompanhando todo esse processo.

Nesse sentido, através de serviços como Abordagem de Rua, inicia-se a atuação da rede de serviços: as pessoas em situação de rua são abordadas e há tentativa de encaminhamento, caso haja interesse por parte delas, para os serviços sócio assistenciais.

Outros serviços, como os Espaços de Convivência, buscam proceder ao atendimento diário, com atendimento, orientações e encaminhamento para serviços da rede conveniada ou demais serviços externos à assistência social. 
O acolhimento noturno, nos centros de acolhida, busca respeitar o estado de fragilidade das pessoas. Dessa forma, para aqueles que se encontram menos fragilizados, há o Centro de Acolhida 16 horas. Se a pessoa se encontra em um estado de maior vulnerabilidade, há o Centro de Acolhida 24 horas, ou mesmo os Centros de Acolhida Especiais, voltados especificamente para certos grupos de pessoas, como mulheres, idosos e pessoas convalescentes.

A rede de serviços também prevê a necessidade de capacitação dos usuários e para isso há serviços específicos voltados para a capacitação profissional, como o Centro de Capacitação Técnica para Adultos em Situação de Rua e o Serviço de Inclusão Social e Produtiva.

Ademais, como já mencionado, a ideia é que as diferentes formas de atuação por parte do poder público acompanhem o grau de autonomia dos usuários e as diferentes etapas do processo de reinserção social. Portanto, a Portaria 46 prevê serviços diversificados, acompanhando a heterogeneidade do perfil do morador de rua.

\subsection{Albergues ou Centros de Acolhida}

Os Centros de Acolhida, também conhecidos como "albergues", são uma realidade constante dentro do dia-a-dia da população em situação de rua. São atualmente um dos principais - senão, o principal - serviços voltados a essa população.

Em São Paulo, foi somente no início da década de 70 que se criaram um dos primeiros serviços públicos que ao menos se assemelhava aos atuais centros de acolhida: o CETREM.

O CETREM (Centro de Triagem e Encaminhamento de São Paulo), localiza-se no Bairro do Cambuci. Inaugurado em 26 de 1971, o CETREM funcionava como um albergue de atendimento diurno e noturno, inclusive aos fins-de-semana, e recebia os migrantes recém-chegados das diversas regiões do país. Em seu primeiro ano de funcionamento, tinha recebido 112.193 migrantes. $^{238}$

As pessoas que procuravam o CETREM eram um público bem específico, em geral pessoas recém chegadas à cidade, e que, por perdas familiares ou falta de recursos,

238 RONCADA, Maria José. Inquérito entre migrantes atendidos pela central de triagem e encaminhamento, na capital do Estado de São Paulo, Brasil. I. Aspectos demográficos. Revista de Saúde Pública, São Paulo. N. 9, pp. 303-312. São Paulo. P. 303. 
utilizavam-se temporariamente desse serviço. Havia também aqueles que se encontravam há pouco tempo na rua, seja por despejo ou por desemprego, e se dirigiam para lá buscando uma recolocação no mercado de trabalho. Como uma central de triagem e encaminhamento, o CETREM oferecia indicações e colocações em empregos, inclusive auxiliando na obtenção de carteira de trabalho. ${ }^{239}$

Os indivíduos que para lá eram encaminhados, ou se dirigiam voluntariamente, tinham diversas solicitações, desde a necessidade de tratamento médico adequado, passando por demandas ligadas ao Serviço Social, até a requisição de documentos e vale transporte ("passes"), para que pudessem ir para o interior do Estado ou para outras unidades da federação. ${ }^{240}$

Pode-se dizer, portanto, que o CETREM representou os primórdios da atual configuração dos centros de acolhida. Contudo, foi somente no governo da Prefeita Luiza Erundina que os primeiros albergues foram criados no centro de São Paulo. Desde lá, o crescimento tanto do número de albergues como do número de vagas é considerável.

De modo a garantir a adequação do serviço prestado, o Decreto no 40.232/2001 descreve os padrões de qualidade que os serviços de abrigo e albergues deverão seguir, esclarecendo que os alojamentos terão número máximo de até 100 (cem) pessoas por unidade conveniada e deverão fornecer condições de pernoite, higiene pessoal, lavagem e secagem de roupas, alimentação, guarda-volumes, trabalho sócio-educativo e serviços de documentação e referência na cidade.

Ademais, o Decreto $n^{\circ} 40.232$ informa também outros requisitos, como a obrigação em manter horários flexíveis para entrada e saída de serviços, de acordo com a necessidade do usuário; alimentação com padrão nutricional adequado, com utilização de pratos e talheres, e serviço com cordialidade; padrões mínimos de higiene no que toca ao acondicionamento de alimentos, roupas de cama, toalhas de banho e travesseiros, além de sanitários limpos e chuveiros com água quente; disponibilização de espaço para lavagem e secagem de roupas para uso pessoal.

O Decreto informa ainda que o espaço físico e as acomodações para a população de rua deverão ser seguros, limpos, confortáveis e arejados, com janelas e iluminação adequadas; as camas ou beliches deverão ter colchões confortáveis e os ambientes

\footnotetext{
239 SIMÕES JUNIOR. José Geraldo. Moradores de Rua. (...) pp. 45-46.

240 RONCADA, Maria José. Inquérito entre migrantes atendidos pela central de triagem e encaminhamento, na capital do Estado de São Paulo, Brasil. I. Aspectos demográficos. (...) p. 303.
} 
precisam garantir a privacidade das pessoas, abrigando no máximo vinte pessoas por dormitório, com espaços demarcados por divisórias. As acomodações devem respeitar, em sua distribuição, o perfil dos segmentos da população de rua (mulheres, portadoras de necessidades especiais, famílias, dentre outros). ${ }^{241}$

Em que pese a grande variedade de serviços previstos na rede conveniada, nota-se que há uma clara tendência de institucionalização de fornecimento de serviços para a população em situação de rua com foco em albergues, revelando um padrão convencional de atendimento às demandas. Em 1993, a Secretaria Municipal do Bem-Estar Social na Região Sé-Lapa registrava 250 vagas, em dois albergues; em 1998, dentro da cidade já havia 1.610 vagas, refletindo um acréscimo de $544 \% .{ }^{242}$ Em outubro de 2005 , a rede de proteção especial da SMADS contava, somente para abrigamento funcionando 24 horas, com 26 albergues e 9 abrigos especiais ${ }^{243}$. Já em 2013, após 8 anos, a rede conveniada contava com 35 centros de acolhida (16 horas e 24 horas) e 15 centros de acolhida especial, com um total de 7.578 vagas.

Percebe-se que o crescimento do número de centros de acolhida também vem acompanhado pelo crescimento do número de moradores de rua e de pessoas albergadas, informações essas indicadas nas contagens e censos da população de rua que vem ocorrendo desde 1991.

Apesar da importância dos Centros de Acolhida para a população de rua - já que estes prestam um serviço efetivamente necessário para várias pessoas que se encontram na rua -, há uma série de problemas ligada aos Centros de Acolhida, como suas condições de atendimento e sua tendência, assim como a de outros serviços existentes, de se circunscreverem basicamente ao atendimento de pernoite, higiene e alimentação, não proporcionando outras formas de orientação, atividades e programas que possibilitem a reinserção social da população de rua. ${ }^{244}$ Nesse sentido, os Centros de Acolhida são vistos por muitos como sendo um local onde as pessoas "se acomodam, recebem tudo de graça e não fazem nada", o que geraria uma população inerte e dependente da Prefeitura a vida inteira, impedindo sua reinserção social. Há quem diga ainda que os Centros de Acolhida podem ser vistos quase como cadeias semiabertas, em decorrência de suas regras rígidas e

\footnotetext{
241 Artigo $6^{\circ}$ do Decreto 40.232/2001.

242 ROSA, Cleisa Moreno Maffei. Vidas de rua. (...) p. 166.

243 Novos albergues terão atendimento personalizado e regras flexíveis. Diário Oficial do Município, de 6 de outubro de 2005, p. II. Notícias.

244 ROSA, Cleisa Moreno Maffei. Vidas de Rua. (...) pp. 166-167.
} 
de seu caráter de fechamento em relação ao mundo exterior. ${ }^{245}$

Um obstáculo grande apresentado pelos Centros de Acolhida é que a maioria deles impõe uma rígida disciplina e não abre mão do horário, tornando difícil a situação daqueles que querem trabalhar ou estudar. ${ }^{246}$ Isso porque parte dos Centros de Acolhida tem horário de entrada entre 17 h00 e 19h30, sem possibilidade de flexibilização. ${ }^{247}$

Ademais, as entidades da rede conveniada possuem regras internas diversas e divergem também quanto ao serviço prestado; esses fatores contribuem para uma falta de homogeneidade dentro da rede de serviços. Há ainda denúncias afirmando que os funcionários nos centros de acolhida em geral são em número insuficiente ou pouco capacitados. $^{248}$

Além disso, os Centros de Acolhida não se apresentam como uma alternativa para moradia definitiva, sendo muito instável a situação daqueles que lá se encontram, pois a qualquer momento, podem perder sua vaga, às vezes até de forma arbitrária, o chamado "desligamento repentino". 249

É necessário se ressaltar que desde o embrião do desenvolvimento de políticas públicas para moradores de rua, o modelo de grandes instituições que forneceriam somente pernoite, banho e alimentação já era visto como improdutivo. ${ }^{250}$ Dessa forma, "ter a população de rua como alvo da atuação institucional é, sem dúvida, relevante, porém são preocupantes as condições de atendimento dos albergues e a tendência de estes e dos demais serviços existentes circunscreverem-se basicamente ao atendimento pernoite, higiene e alimentação." 251

Nesse sentido, em que pese o crescimento e a complexidade, de forma geral, dos serviços prestados à população em situação de rua, o modo como essa rede vem sendo gerenciada contribuiu para um aumento maciço e prioritário no número de centros de acolhida, tornando essa política o eixo principal de atuação do governo municipal em face de se haver outras demandas e necessidades por parte da população em situação de rua, o

245 BARROS, Joana da Silva. Moradores de Rua: pobreza, trabalho: interrogações sobre a exceção e a experiência da política brasileira (...) p. 65.

246 Vida no trecho: histórias de estudo no trecho. O Trecheiro. Fevereiro de 2009. p. 4.

247 COSTA, Daniel de Lucca Reis da. A rua em movimento: Experiências urbanas e jogos sociais em torno da população em situação de rua. (...) pp. 197 e ss.

248 Organizações sociais e usuários: problemas (históricos) e ainda mais atuais. O Trecheiro. Agosto de 2006. p. 3.

249 Albergue nem pensar! O Trecheiro. Julho de 2009. p.1.

${ }^{250}$ ROSA, Cleisa Moreno Maffei (org.). População de rua: Brasil e Canadá. São Paulo: Hucitec, 1995.

251 ROSA, Cleisa Moreno Maffei. Vidas de rua. São Paulo: Hucitec: Associação Rede Rua: 2005. P. 166167. 
que se mostra até contraditório e, em certa medida, preocupante.

\subsection{Reações da sociedade}

Antes de iniciarmos o estudo de caso, no próximo capítulo, buscaremos investigar nesse tópico as formas pelas quais a sociedade reage em relação à população em situação de rua. Sabe-se que a presença de indivíduos em situação de rua nos grandes centros urbanos já se tornou um aspecto que dificilmente passa despercebido na rotina das pessoas. Cotidianamente, são diversas as formas pelas quais a sociedade lida com essa questão, que pode variar entre abordagens repressivas até tentativas de auxílio.

Em seus estudos sobre a população de rua em Austin, Texas, Snow e Anderson organizaram essas respostas, e chegaram a uma tipologia, que variava de acordo com o trabalho desenvolvido pelas associações que lidavam com a população de rua e a ideologia de trabalho por trás de suas atuações. Foram criadas cinco categorias, de acordo com o tipo de resposta: acomodativo, restaurativo, explorativo, de expulsão (ou exclusão) e de contenção. $^{252}$ Mesmo tendo sido criado em um contexto diverso do brasileiro, as semelhanças entre a tipologia criada por Snow e Anderson são aplicáveis à realidade nacional, como se verá a seguir.

O modelo acomodativo se caracteriza por pessoas ou grupos de pessoas que oferecem ajuda de diversas formas, sendo o objetivo a ajuda em sim mesma, e não a prestação de um auxílio como meio para se chegar a um objetivo mais importante. Tal modelo se atenta principalmente às necessidades básicas dos moradores de rua, como alimentação e locais para pernoitar. O modelo clássico dos albergues ou centros de acolhida se encaixa nesse perfil. Oferecendo refeições, espaço para higiene e acomodação, os centros de acolhida podem ser mais ou menos liberais, dependendo da permissão quanto à duração da estadia e das regras internas do serviço ${ }^{253}{ }^{254}$

252 SNOW, David. A, ANDERSON, Leon. Down on their luck: a study of homeless street people. (...) pp. 77-78.

253 Horários estritos para entrada e saída dos usuários, possibilidade ou não de entrar no serviço embriagado ou drogado, possibilidade ou não de entrar com álcool ou drogas no serviço, dentre outras.

254 Em São Paulo, os centros de acolhida se organizam através de duas formas: pernoite e vaga fixa. O pernoite, como indica o próprio nome, refere-se à acomodação individual, somente para uma noite. O usuário não tem vaga garantida, e na noite seguinte terá que se submeter novamente a um processo de seleção por parte do centro de acolhida a fim de pernoitar novamente. Já a vaga fixa garante, por algum tempo ao menos, uma vaga em um centro de acolhida, contanto que o usuário obedeça as regras internas do estabelecimento. Há regras, contudo, no que toca ao tempo máximo possível dos serviços de um 
Em que pese a enorme utilidade de tais serviços para manter a vida na rua como algo minimamente viável, as respostas acomodativas não oferecem os instrumentos necessários que viabilizem a saída da vida das ruas. Os serviços voltados à população de rua com esse perfil tendem a negligenciar aspectos como suporte moral e o resgate econômico de tais pessoas. ${ }^{255}$ Por se focarem somente no presente e, em geral, em aspectos de sobrevivência diária, as respostas acomodativas geralmente mantém a ligação entre os usuários do serviço e a rua, o que é prejudicial.

Ademais, ocorre que muitos moradores de rua tendem a não se valer dos serviços prestados pelos centros de acolhida, por diversos motivos: regras internas muito rígidas, tratamento impessoal, serviços mal prestados, condições desumanas, dentre outros. ${ }^{256}$ Informações semelhantes foram obtidas quanto à cidade de São Paulo, sendo notada a falta de flexibilidade nos horários, críticas sobre o tratamento recebido e falta de funcionários.

Todavia, em certas situações, como em casos de condições meteorológicas desfavoráveis (chuva e frio), fome e motivos de higiene (banho ou uso dos serviços de lavanderia), mesmo os moradores de rua mais relutantes acabam se utilizando dos serviços dos centros de acolhida, ${ }^{257}$ situação esse também comum no contexto paulistano. ${ }^{258}$

O segundo modelo de respostas refere-se ao modelo restaurativo. Diferentemente das respostas de caráter acomodativo, mais focada em uma perspectiva da satisfação de necessidades básicas, a resposta restaurativa buscar atender aos problemas psicológicos,

centro de acolhida em específico, o que não impede a utilização dos serviços dos demais centros de acolhida restantes.

255 SNOW, David. A, ANDERSON, Leon. Down on their luck: a study of homeless street people. (...) pp. 78-79.

256 SNOW, David. A, ANDERSON, Leon. Down on their luck: a study of homeless street people. (...) p. 80.

257 Vida no trecho: histórias de estudo no trecho. O Trecheiro. Fevereiro de 2009. p. 4; O Trecheiro. Organizações sociais e usuários: problemas (históricos) e ainda mais atuais. Agosto de 2006. p. 3; COSTA, Daniel de Lucca Reis. A rua em movimento: Experiências urbanas e jogos sociais em torno da população em situação de rua. (...) pp. 197 e ss.

258 Em São Paulo, há a Operação "Baixas Temperaturas”, que ocorre entre o início do mês de maio até o fim do mês de outubro, quando a previsão da temperatura na cidade está inferior a 13 graus centígrados. $\mathrm{O}$ procedimento se inicia pela prevista do tempo, preparada pelos meteorologistas do Centro de Gerenciamento de Emergências. Com temperaturas inferiores a 13 graus, o sistema entra em estado de atenção com intensificação das rondas por parte da Central de Atendimento Permanente. Se a previsão de temperaturas é abaixo de 10 graus, o sistema entra em estado de alerta, todas as folgas são suspensas, com o objetivo de procurar pessoas desassistidas pela cidade, que caso contrário, correm riscos de morrer de fome ou frio. (O difícil resgate dos sonhos. Diário Oficial do Município, de 20 de agosto de 2006, pg. III). Por meio dessa Operação, em 2013, além das 9 mil vagas disponíveis nos 63 albergues da cidade, são disponibilizadas 3 mil vagas adicionais, decorrente da situação emergencial decorrente do frio. In: Com nova frente fria, Prefeitura intensifica ações para pessoas em situação de rua. In: http://www.prefeitura.sp.gov.br/cidade/secretarias/comunicacao/noticias/?p=154504 (acesso em 10/11/2013); Com frente fria, São Paulo intensifica ações para pessoas em situação de rua. In: http://www.redebrasilatual.com.br/cidadania/2013/07/com-frente-fria-prefeitura-intensifica-acoes-parapessoas-em-situacao-de-rua-3555.html (acesso em 10/11/2013). 
fisiológicos e espirituais que afligem os moradores de rua e impedem seu desenvolvimento. Exemplos de associações que se valem desse viés são as instituições voltadas para a saúde mental, centro de reabilitação de usuários de droga e álcool, serviços de aconselhamento variados, apoio religioso-espiritual e capacitação profissional. Tais instituições não se focam no problema de se estar na rua per se: ao contrário, a atenção dessas organizações se volta para os indivíduos e seus problemas, sejam eles psicológicos, psiquiátricos ou decorrentes de seus estilos de vida. ${ }^{259}$

Contudo, é necessário ressaltar que mesmo nos serviços de tipo restaurativo, a saída das ruas não é garantida. Isso é muito comum nos casos de usuários de droga ou de álcool. Ainda que haja recuperação desses indivíduos, a alta faz com que tais pessoas invariavelmente retornem às ruas, retornando, invariavelmente, aos antigos hábitos de consumo de álcool e drogas.

Dessa forma, seja por meio da perspectiva médica ou da espiritual, por não ofertarem alternativas que permitam com que os moradores de rua retornem ao mundo domiciliado, tais instituições acabam ajudando pouco. ${ }^{260}$ Nesse contexto, a capacitação profissional adquire peso maior, por permitir, em tese, a saída das ruas.

Uma terceira forma de resposta é a resposta exploradora, no qual as pessoas em situação de rua são captados por intermédio de uma perspectiva de mercado. Por esse viés, os moradores de rua são vistos como fonte de mão-de-obra barata ou como meros consumidores comuns. Em Austin, a doação de sangue é remunerada, e há também a possibilidade de contratar moradores de rua para trabalhar durante o dia, descarregando caixas, realizando pequenos serviços, trabalhando na construção civil, funções, em geral, de baixa qualificação. Contudo, em que pese se tratarem de oportunidades em que os moradores de rua obtêm alguma renda para a sobrevivência diária, trata-se de uma relação desigual e exploradora, pois se "lucra" sobre o trabalho dessas pessoas a uma razão muito superior aos valores recebidos por elas como remuneração. ${ }^{261}$ Em São Paulo, com exceção

259 Os autores buscam explicar a grande incidência do tratamento de curtíssima duração como consequência dos problemas médicos geralmente enfrentados pelos moradores de rua, como cortes, fraturas, problemas de pele e problemas decorrentes do uso de drogas e álcool. Em que pese se tratar de problemas agudos e não crônicos, e que por consequência não demandariam, per se, internação hospitalar, é fato que o processo de cura desses problemas médicos seria mais efetivo caso houve internação, tendo em vista as circunstâncias pouco favoráveis pelos quais passam os moradores de rua em suas jornadas diárias, o que certamente não colabora para a recuperação dos doentes.

260 SNOW, David. A, ANDERSON, Leon. Down on their luck: a study of homeless street people (...) pp. 87-91.

261 SNOW, David. A, ANDERSON, Leon. Down on their luck: a study of homeless street people. (...) pp. 94-95. 
da doação de sangue remunerada, todos os exemplos acima são bem comuns.

Um quarto modelo de resposta caracteriza-se pela resposta focada na exclusão ou expulsão. Em suas rotinas diárias, as pessoas em situação de rua são alvos de práticas sociais que podem variar entre atitudes de completa generosidade até manifestações de hostilidade. Tais práticas variam com o tempo e com o local, havendo predomínio de uma ou de outra, e por consequência, acabam influenciando a rotina dos moradores de rua. ${ }^{262}$

Nesse sentido, caso a comunidade de certo local esteja mais inclinada a ver os moradores de rua como vítima de problemas sociais e como pessoas que tiveram "má sorte" na vida, as práticas sociais em relação a esses indivíduos tenderão à generosidade. $\mathrm{O}$ mesmo pode ser dito quando a compreensão da sociedade, em termos gerais, é de entender os moradores de rua como cidadãos, ou seja, pessoas que possuem direitos que devem ser respeitados e garantidos.

De outro lado, caso haja consenso em atribuir a essas pessoas a completa responsabilidade por seus destinos, se entendendo que estas se encontram nessa situação devido à ausência de dedicação aos estudos ou ao trabalho, por consequência, os moradores de rua são vistos como pessoas que escolheram uma vida de miséria, e que, portanto, não merecem solidariedade.

Dessa forma de pensamento, decorrerão atitudes “expulsionistas", que entendem que os moradores de rua não podem habitar, utilizar e transitar por certos espaços públicos da cidade, decorrendo, daí, uma série de medidas restritivas por meio de leis ou mesmo somente por práticas sociais reiteradas. É comum também a remoção dos moradores de rua de locais objeto de valorização imobiliária, onde ocorre a especulação urbana e práticas de gentrificação. $^{263}$

Como se verá a seguir, essa abordagem voltada à expulsão não é algo incomum no contexto paulistano.

Por fim, há ainda a abordagem da contenção, representada principalmente por meio da utilização da força policial. A presença de pessoas em situação de rua pode ser vista como uma "ameaça" à ordem pública, sendo necessária a vigilância e eventualmente a intervenção policial a fim de retirar tais pessoas da circulação e do campo de visão dos demais cidadãos. Tais atitudes em geral vêm associadas a constrangimentos e possíveis

262 SNOW, David. A, ANDERSON, Leon. Down on their luck: a study of homeless street people. (...) pp. 95-96.

263 SNOW, David. A, ANDERSON, Leon. Down on their luck: a study of homeless street people. (...) pp. 97-98. 
agressões e excessos por parte dos policiais. ${ }^{264}$ Não é incomum também a própria criminalização do modo de vida dessas pessoas, por exemplo, através dos delitos de vadiagem e mendicância, como exemplifica a legislação nacional. ${ }^{265}$

Pela tipologia acima descrita buscou-se somente organizar algumas das formas pelas quais as pessoas em situação de rua são vistas pela sociedade. Em geral, as práticas acima descrita tendem a ocorrer numa mesma sociedade, com maior preponderância de um tipo ou de outro.

Como se virá a seguir, a tipologia acima empregada terá utilidade prática na análise das reações da sociedade e do poder público em face da população de rua na cidade de São Paulo.

264 SNOW, David. A, ANDERSON, Leon. Down on their luck: a study of homeless street people. (...) pp. 98-102.

265 Lei de Contravenções Penais (Decreto-Lei no 3.688, de 3 de Outubro de 1941), artigo 25. 


\section{PROJETO OFICINA BORACEA}

O contexto até aqui examinado foi necessário para que se compreendesse o objeto de análise do presente trabalho: o estudo de um centro de serviços na cidade de São Paulo inserido na política pública municipal de atenção a pessoas em situação de rua.

Dessa forma, procurou-se situar o atual arcabouço jurídico em que se insere a política da assistência social, regulada por marcos constitucionais e legais, que reforçam e regulamentam o dever do Estado em fornecer serviços públicos para pessoas que se encontram em estado de vulnerabilidade e carência. Dentre esses grupos, há previsão expressa na Lei Orgânica de Assistência Social, afirmando a necessidade de se idealizar serviços voltados especificamente para a população em situação de rua.

Como já mencionado, para a prestação dos serviços assistenciais, além de prestação direta pelo poder público, há a possibilidade de arranjos institucionais entre sociedade civil e poder público, na forma de parcerias e convênios, que na cidade de São Paulo, representa a maioria dos serviços prestados. ${ }^{266}$

Com o fim de estudar os serviços públicos voltados para a população em situação de rua, decidiu-se estudar um centro de serviços representativo do universo das políticas públicas focadas nesse grupo: o Projeto Oficina Boracea.

O Projeto Oficina Boracea foi lançado em 15 de maio de 2002, tendo sido apresentado como conjunto de serviços e abrigo ao público em 26 de junho de $2003 .{ }^{267}$ Localizado em um terreno de $17 \mathrm{mil} \mathrm{m}^{2}$, a concepção inicial do Projeto envolvia serviços de arte, cultura, educação e profissionalização, voltados, prioritariamente, à acolhida de catadores de materiais recicláveis, além de idosos e adultos. O Projeto também se direcionava para a reconstituição de vínculos e o desenvolvimento de capacidades para a construção de autonomia e alternativas de reinserção social à população de rua. ${ }^{268}$

Por ter uma proposta diferenciada, o Projeto chamou a atenção de outros países, e foi visitado por delegações do Japão, Canadá, Alemanha e França, assim como pelas Prefeituras de algumas cidades do interior de São Paulo e de outros Estados brasileiros. O

266 RAMOS, Ana Márcia Fornaziero. Potencialidades e desafios nas parcerias entre a secretaria municipal de assistência Social e desenvolvimento social e as entidades sociais na cidade de São Paulo: um estudo dos serviços voltados para a população em situação de rua. Doutorado em Ciências Sociais. Pontifícia Universidade Católica de São Paulo. p. 61.

267 Simões, Janaina Machado. Projeto Oficina Boracea. São Paulo -SP. p. 208.

268 Simões, Janaina Machado. Projeto Oficina Boracea. São Paulo -SP. pp. 208-209. 
modelo do Projeto foi considerado por essas delegações como uma forma de se estabelecerem diretrizes de intervenção que fugissem de um caráter puramente emergencial, compreendendo as pessoas em situação de rua como sujeitos de direitos e não apenas objeto de compaixão ${ }^{269}$.

O Projeto também foi premiado como um dos melhores programas de gestão pública e cidadania pela Fundação Getúlio Vargas em $2004^{270}$ e foi um dos principais serviços criados durante o mandado da Prefeita Marta Suplicy.

Contudo, no início da gestão do Prefeito José Serra ${ }^{271}$, o Projeto foi ameaçado de ser fechado, por ser considerado grande, caro e ineficaz. O Secretário de Desenvolvimento e da Assistência Social da época alegou que estruturas menores, para cem pessoas, eram o ideal em termos de serviços voltados para a população de rua.

Atualmente, o Projeto Oficina Boracea se mantém em funcionamento, mas assumiu nova roupagem, além da modificação em seus serviços, pois não tem mais como público prioritário os catadores de material reciclável. O terreno e os prédios ocupados pelo Projeto agora sediam o Complexo Boracea, que reúne em um só local uma série de serviços, dentre eles restaurante, lavanderia e centro de acolhida. O Complexo Boracea vem previsto no rol de serviços disponíveis à assistência social dentro da rede de serviços de proteção especial de alta complexidade. ${ }^{272}$ No mesmo espaço, há um CREAS POP (serviço administrado diretamente pelo Governo Municipal), um Espaço de Convivência, serviços voltados para pessoas convalescentes e idosos (CAE) -, um Centro de Acolhida para Mulheres e três Centros de Acolhida para homens - o Centro de Acolhida Barra Funda I, Centro de Acolhida Barra Funda II e Centro de Acolhida Oficina Boracea, além de lavanderia e restaurante.

Assim, o Complexo Boracea se mostrou um equipamento privilegiado em termos de proposta, estrutura, quantidade de pessoas e repasse de verbas pela Prefeitura, ${ }^{273}$ motivo pelo qual foi escolhido como mais adequado para o estudo de caso, por ser representativo do modelo de centro de acolhida implementados pela Prefeitura de São Paulo.

\footnotetext{
269 VICTORIANO, Eliana Fernandes Loureiro. Projeto Oficina Boracea. (...) p.68.

27020 Experiências de Gestão Pública e Cidadania. São Paulo: Programa Gestão Pública e Cidadania. 2004.

271 Serra decide desativar albergue modelo. Folha de São Paulo. 05/10/2005.

272 Portaria n. 46/2010 da Secretaria Municipal de Assistência e Desenvolvimento Social de São Paulo. p. 6

273 Cf. Planilha Padrão para Cálculo de Custos. Centro de Acolhida 24 horas. Prefeitura de São Paulo Assistência Social; Planilha Padrão para Cálculo de Custos dos Centros de Acolhida 16 horas. Valores previstos de acordo com a Portaria 47/SMADS/2010.
} 


\subsection{O programa "Acolher: Reconstruindo Vidas"}

Nessa primeira parte, será exposta a ideologia por detrás do Projeto Oficina Boracea, e as intenções por parte da Secretaria da Assistência Social ao idealizar o Projeto.

A concepção do Projeto Boracea, lançado como projeto em 15 de maio de 2002, e inaugurado como conjunto de serviços e abrigo ao público em 16 de junho de 2003, ocorreu durante o mandato da Prefeita Marta Suplicy (2001-2004), tendo como Secretária Municipal da Assistência Social a ex-vereadora Aldaíza Sposati.

O Projeto Oficina Boracea foi idealizado no bojo do Programa Acolher: Reconstruindo Vidas ${ }^{274}$, iniciando a implementação e concretização dos dispositivos contidos no Decreto 40.232/2001. Lançado na mesma data em que o Oficina Boracea, ${ }^{275} \mathrm{o}$ Programa Acolher voltava-se especificamente à população em situação de rua e buscava reunir e integrar as práticas já desenvolvidas pelas entidades e organizações da sociedade civil, representantes das secretarias municipais, pesquisadores e as próprias pessoas em situação de rua, em prol da articulação de um novo projeto de política pública.

Partia-se da compreensão de que para a implementação de uma política pública eficaz, deveriam ser superados diversos desafios, como o imediatismo das ações voltadas para a saída das ruas. Ao contrário, pelo novo paradigma criado pelo Programa Acolher, o longo processo de reinserção social dessas pessoas passa a ser o foco de acompanhamento, e não de imediatismos, pautando-se em uma política municipal com viés intersetorial, com profissionais preparados e capacitados. ${ }^{276}$

O desafio da nova gestão era estruturar uma política pública que acompanhasse os usuários da porta da entrada até a porta de saída, com albergues que funcionassem durante o dia e que disponibilizassem uma multiplicidade de serviços. Para tornar possível a saída das ruas, a atuação do poder público ocorreria desde a abordagem inicial até a formulação e auxílio em formas organizadas de trabalho, de novos vínculos sociais, a fim de possibilitar um caminho para a autonomia.

Para tanto, foram desenvolvidos 6 eixos $^{277}$ :

\footnotetext{
274 Folder "Acolher: Reconstruindo Vidas”. Secretaria Municipal de Assistência Social. Prefeitura de São Paulo.

275 Programa Acolher: Reconstruindo Vidas. O Trecheiro. Maio de 2002. P. 4

276 Folder "Acolher: Reconstruindo vidas". Secretaria Municipal da Assistência Social. Prefeitura de São Paulo.

277 PONTIFÍCIA UNIVERSIDADE CATÓLICA DE SÃO PAULO. INSTITUTO DE ESTUDOS
} 
(i) Formação de equipe de campo, por meio da Central de Atendimento Permanente e de Emergência (CAPE).

(ii) Reestruturação dos abrigos espalhados na cidade. Além dos serviços já existentes - 35 albergues e abrigos com capacidade para 4.941 vagas, sendo que 10 deles funcionavam 24 horas -, em face da heterogeneidade dos usuários, foram desenvolvidos novos serviços voltados especificamente para família, idosos e pessoas com demandas voltadas à problemas de saúde.

(iii) Moradias provisórias: na época, a Secretaria de Assistência Social contratou 13 casas e prédios - com total de 448 vagas - para acolher pessoas em processo de reinserção social, possibilitando o exercício da autonomia dessas pessoas.

(iv) Reformulação e consolidação das políticas emergenciais de acolhimento durante o inverno, sendo renovados todos os anos os convênios para a garantia de acolhimento emergencial no período das frentes frias, e intensificado os trabalhos para evitar sofrimento e morte causadas em decorrência do frio.

(v) Espaços de convívio existentes na cidade, sendo 8 o número de casas de convivência, centradas no convívio grupal e no estabelecimento de vínculos com os usuários. Nesses locais, eram fornecidas ofertas diárias de serviços, além de ações socioeducativas que estimulassem a sociabilidade e organização em grupos.

(vi) Inserção produtiva, voltada para os indivíduos que se sentiam em condições de iniciar projetos de inserção social. Dessa forma, foram criadas diversas oportunidades, sob a forma de participação em cooperativas ou em cursos profissionalizantes, tendo por objetivo requalificar a população em situação de rua para competir no mercado de trabalho ou mesmo iniciar um novo empreendimento por conta própria, com foco principalmente nas áreas de construção civil, costura, estética (cabelereiro e manicure), artesanato e marcenaria.

A rede de serviços articulada em torno do Programa Acolher possuía três vertentes: acolhida, convívio e autonomia. Em cada uma das modalidades, foram instalados serviços 
adequados para a orientação contínua das pessoas em situação de rua.

No que toca à acolhida, foram elencadas as seguintes modalidades de serviços: albergue, abrigo, hospedagem e moradias provisórias, além da bolsa aluguel. ${ }^{278}$

O convívio ocorreria por meio dos centros de serviços, que foram expandidos, como, por exemplo, através da instalação do Projeto Oficina.Boracea.

No que toca à autonomia, foram tomadas as seguintes medidas:

(i) Benefícios da Prestação Continuada: previsto na Lei Orgânica da Assistência Social (LOAS), para pessoas com mais de 65 ou com deficiência, o BPC representa um benefício mensal no valor de um salário mínimo. Através de um entendimento entre o município e o INSS, foi possível fornecer o endereço dos albergues e abrigos como endereço para se receber o benefício.

(ii) Instalação de oficinas de desenvolvimento de qualificação profissional, como os serviços de Lavanderia-Escola e Restaurante-Escola, inclusive com treinamento e oferecimento de serviços para serem utilizados pela própria rede socioassistencial.

(iii) Cooperativas de Oficinas de Inclusão Produtiva, com serviços de elétrica, hidráulica, construção civil, com oferecimento de serviços voltados para a conservação da própria rede.

(iv) Instalação de duas lojas sociais, sendo uma delas dentro da Oficina.Boracea, para comercialização de produtos.

É nesse contexto que o Projeto Oficina.Boracea foi planejado: como peça central dentro do Projeto Acolher, atuando como espaço de referência, onde seria possível se prover uma conjunto de seguranças sociais: ${ }^{279}$

(i) Possibilidade de acolhida que preservassem a dignidade, a autonomia e a

278 Os albergues eram divididos entre albergues noturnos ou albergues com serviços. Havia ainda a possibilidade de albergues para pessoas com deficiência e também vagas específicas para catadores de materiais recicláveis. Os abrigos eram voltados para pessoas com necessidades especiais, que exigiam maior tempo de permanência e cuidados intensivos, como idosos, mulheres com crianças, drogaditos e pessoas com problemas de saúde mental. As moradias provisórias consistiam em repúblicas instaladas em casas alugadas e montadas pela Prefeitura, onde grupos de 10 a 15 pessoas, mantinham-se coletivamente por algum tempo, até ser encontrada uma solução definitiva. De acordo com o tipo de moradia provisória, as vagas era destinadas somente para adultos do mesmo sexo, de ambos os sexos, somente idosos, ou idosos e jovens. Por sua vez, a bolsa aluguel representava um auxílio mensal de R\$ 300,00, mantido por um certo período de tempo.

279 Documento Projeto Acolhe: Reconstruindo Vidas. Prefeitura Municipal de São Paulo. Secretaria Municipal de Assistência Social. Gabinete da Secretária da Assistência Social. 
individualidade;

(ii) Organização de espaços para guardar instrumentos de trabalho e objetos de uso pessoal;

(iii) Junção, ao mesmo tempo, de serviços de atendimento a necessidades básicas de higiene, alimentação e cuidado pessoal, além de espaços para descanso e lazer, e oficinas de promovessem o desenvolvimento de capacidades, fortalecimento de autoestima e resgato de vínculos familiares e grupais;

(iv) Acesso às demais políticas públicas.

Dessa forma, tanto o Programa Acolher como o Projeto Oficina Boracea buscavam alterar os padrões existentes na época no que tocava aos serviços voltados à população em situação de rua, muito focados somente na acolhida dessas pessoas, sem atentar a outras necessidades. O objetivo central do projeto era criar uma cultura de direitos em relação à população em situação de rua, prestando serviços de qualidade para que tais pessoas se reinserissem socialmente e resgatassem sua autonomia.

\subsection{A inserção do Complexo Boracea na Rede de Atendimento}

O projeto Oficina Boracea foi inaugurado como sendo o maior equipamento dentro do Programa Acolher: Reconstruindo Vidas. O público-alvo do Boracea eram as pessoas em situação de rua, em especial os catadores de materiais recicláveis. Partia-se do pressuposto que, apesar de existirem albergues e abrigos com vagas em aberto, os catadores de materiais recicláveis resistiam a passar a noite nesses locais, já que não havia estacionamento para seus carrinhos, ou mesmo um local para deixar seus animais de estimação, tendo em vista que $20 \%$ dos catadores os possuíam. ${ }^{280}$

Naquela época, em São Paulo, havia somente um albergue - Dom Bosco - que cobria a necessidade de alojamento dessa população de carrinheiros, sem, contudo, possibilitar a acomodação de animais, fazendo com que essas pessoas optassem por permanecer nas ruas. ${ }^{281}$

Além da possibilidade de acolhida dos carrinheiros, o Projeto também buscava

280 Folder "Projeto.Oficina.Boracea". Secretaria Municipal da Assistência Social. Prefeitura de São Paulo.

281 VICTORIANO, Eliana Fernandes Loureiro. Projeto Oficina Boracea. (...) p.57-58. 
fornecer uma série integrada de serviços, possibilitando, inclusive, que os catadores de materiais pudessem negociar sua mercadoria sem intermediários.

Para tanto, os catadores receberiam um vale, que poderia ser trocado no posto Bancário da Caixa Econômica Federal, instalado dentro do Projeto.

No que toca à acolhida, seriam disponibilizados 500 leitos, a serem utilizados individualmente ou por famílias. O restaurante do Projeto seria estruturado para o oferecimento de duas mil refeições ao dia. A lavanderia funcionaria como uma oficina de trabalho, permitindo a geração de renda; parte da Lavanderia seria industrial, e seria utilizada tanto para lavar a roupa dos albergues e abrigos existentes na rede naquele momento, como para permitir que os moradores de rua lavassem suas roupas individualmente. $^{282}$

No local também seriam disponibilizadas: cinemateca, sala de leitura, oficinas profissionalizantes, horta-comunitária; guarda-volume e maleiro; salão de múltiplo uso para oficinas de teatro, música e palestras; ambulatório com posto de atendimento médico e um instituto de estudos sobre moradores de rua e espaço urbano. Por fim, haveria ainda uma sala de informática. ${ }^{283}$

Uma inovação do Projeto também vinha no oferecimento de 50 vagas de acolhida durante o dia, destinadas às pessoas que trabalham durante a noite ${ }^{284}$.

O projeto seria coordenado pela Secretaria de Assistência Social, mas contaria com a parceria com as secretarias de Saúde, Trabalho, Meio Ambiente, Serviços e Obras, Abastecimento, Esporte e Cultura. ${ }^{285} \mathrm{~A}$ intenção, portanto, era prestar um serviço multifacetado e intersecretarial.

Por todas as características acima narradas, percebe-se que o Projeto tinha por intenção ser uma unidade de referência na reinserção social das pessoas em situação de rua. De acordo com a Secretária da Assistência Social na época, Aldaíza Sposati, a iniciativa apresentada pela Prefeitura buscava romper com a ideia de que os moradores de rua deveriam ser tratados de forma precária, ou tratados de forma repressiva e policialesca por parte dos albergues e abrigos:

282 Folder "Acolher: Reconstruindo vidas". Secretaria Municipal da Assistência Social. Prefeitura de São Paulo.

283 Folder "Acolher: Reconstruindo vidas". Secretaria Municipal da Assistência Social. Prefeitura de São Paulo.

284 Oficina Boracea: Um ambicioso projeto social. Jornal do Bom Retiro. Junho/2002.

285 Folder "Acolher: Reconstruindo vidas". Secretaria Municipal da Assistência Social. Prefeitura de São Paulo. 
"O Boracea não é um depósito de gente. O que está por trás é a filosofia da dignidade humana e o conceito de sutileza no trato. Procuramos soluções inovadoras. É uma verdadeira mudança de mentalidade" 286.

A filosofia por detrás do Projeto era uma abordagem pedagógica do direito e da emancipação, buscando a reflexão a partir de situações do cotidiano e do incentivo à participação dos indivíduos. $^{287}$

Além de toda a filosofia por detrás do Projeto, associada à inovação que este procurava trazer em termos de tratamento da questão das pessoas em situação de rua, a instalação desse serviço no bairro da Barra Funda era estratégico por vários motivos.

Por se localizar na região central, tendo em vista o percurso de boa parte dos moradores de rua, o Projeto Boracea também estaria próximo de pontos de coleta e de venda de materiais recicláveis, em particular, de duas cooperativas: a COORPEL, no bairro da Luz, e a RECICOOPER, na Sé. A facilidade de acesso à coleta de materiais recicláveis é relevantíssima nesse contexto, principalmente ao se considerar que o Complexo Boracea fora erigido justamente para tentar atender à demanda de catadores de materiais recicláveis, que possuíam poucas oportunidades em termos de serviços assistenciais.

Por fim, a proximidade a três Universidade facilitaria a celebração de parcerias, experiência esta já desenvolvida pelo albergue Arsenal da Esperança, no Brás, cujo projeto de reforma fora desenvolvido com o auxílio de uma Universidade localizada próximo ao albergue. $^{288}$

\subsection{O projeto inicial desenvolvido e a reforma empreendida}

O Projeto Boracea foi lançado como projeto em 15 de maio de 2002, e inaugurado como conjunto de serviços e abrigo ao público em 26 de junho de 2003. Nesse meio tempo, as ideias relativas ao Projeto foram se desenvolvendo.

O espaço de $17 \mathrm{mil} \mathrm{m}^{2}$ a ser ocupado pelo Projeto era uma antiga oficina para reparo de veículos pertencente à Prefeitura ${ }^{289}$. Esses antigos galpões de transportes foram

286 SP vai atender catador e seu melhor amigo. Folha de São Paulo. 15/12/2002.

287 SIMÕES, Janaína Machado. Projeto Oficina Boracea. p. 209.

288 ENDRIGUE, Taisa da Costa. Repensando o Projeto Boracea - Proposta de Abrigo para moradores de rua da Cidade de São Paulo. Trabalho Final de Graduação, Faculdade de Arquitetura e Urbanismo, USP, 2002. pp. 30.

289 SP vai atender catador e seu melhor amigo. Folha de São Paulo. 15/12/2002. 
reformados e adaptados a fim de viabilizar o novo serviço.

A reforma dos galpões foi projetada voluntariamente pelo arquiteto Roberto Loeb, tendo por objetivo fornecer à população em situação de rua um novo conceito de atendimento, onde o espaço se adapta ao usuário, e não o contrário. ${ }^{290} \mathrm{Na}$ planta original, era prevista a existência de 13 blocos ${ }^{291}$, sendo destacáveis alguns aspectos: ${ }^{292}$

A recepção se apresentava como espaço intermediário entre os ambientes interno e externo, e buscava evidenciar o respeito e valorização do usuário, oferecendo conforto e bem-estar. Incluía área de estar, para descanso e leitura, central de informações e orientações, lanchonete, central de informática e agência bancária.

O espaço também foi projetado com estufa e horta comunitária, a ser desenvolvida e gerenciada pelos usuários. Na entrada também foi idealizada uma Loja/Brechó, para a comercialização de produtos reciclados e roupas de baixo custo.

Da recepção, chegava-se a um pátio central arborizado, com uma capela que seria restaurada. Além disso, haveria um espaço para uma fogueira central, em torno do qual poderiam ser feitas reuniões.

Planejou-se ainda um alojamento específico para carrinheiros, com espaços individuais, e redes, caso quisessem dormir junto de seus carrinhos. Havia também um canil, com atendimento veterinário, e um pátio específico para coleta e triagem de materiais recicláveis.

Outro ponto a ser destacado é o alojamento para até 400 pessoas: era prevista a existência de divisórias móveis, para tornar o arranjo interno versátil aos diferentes tipos de usuários (famílias e pessoas sozinhas). Foi projetado também um alojamento emergencial, com espaço para redes e barracas, caso fosse necessário aumentar a capacidade de acolhimento noturno.

Havia locais específicos para oficinas profissionalizantes, assim como um espaço

290 Oficina Boracea: Um ambicioso projeto social. Jornal do Bom Retiro. Junho/2002.

291 Bloco A: recepção, estufa/horta comunitária e loja/brechó; Bloco B: alojamento dos carrinheiro; praça/capela/fogueira; Bloco C: canil e atendimento feito pela zoonose; Bloco D: Lavanderia comunitária; Bloco E: alojamento permanente, espaço para alojamento emergencial, maleiro e guardavolumes; Bloco F: Centro de estudos e pesquisas sobre a população de rua e centro de documentação, e sala de informática; Bloco G: espaço para oficinas profissionalizantes e para exposições; Bloco H: posto para atendimento por assistentes sociais; Bloco I: alojamento para a terceira idade, lanchonete/cozinha/restaurante, salão comunitário/cinema/teatro; Bloco J: sala do bairro; Bloco K: base da Polícia Militar e Sala da Comunidade; Bloco L: pátio de coleta/triagem de materiais recicláveis; Bloco M: área de esportes.

292 ENDRIGUE, Taisa da Costa. Repensando o Projeto Boracea - Proposta de Abrigo para moradores de rua da Cidade de São Paulo. (...) pp. 25-27. 
para atividades de lazer, como cinema, teatro e práticas esportivas. No espaço da cozinha, os usuários poderiam preparar suas próprias refeições. No futuro, a cozinha seria utilizada para a realização de cursos profissionalizantes voltados para o preparo de refeições e atividades de manejo de restaurantes.

Haveria ainda uma sala ("sala do bairro"), na qual se realizariam reuniões para discutir questões referentes ao bairro. Outro espaço seria disponibilizado para promover a interação entre usuários e funcionários do programa com os moradores do bairro. Por fim, prevista também o espaço para uma base da polícia militar.

Percebe-se, portanto, que o projeto buscava integrar uma série de atividades em um mesmo espaço, sem se reduzir somente às funções "comuns" aos albergues, que normalmente se restringiam serviços de pernoite, alimentação e higiene.

Contudo, apesar de diversos méritos do Projeto, já é possível se vislumbrar alguns problemas, como o tamanho do serviço, muito maior do que o recomendado pela lei municipal 12.316/97.

Ademais, já no início das reformas empreendidas, a iniciativa da Prefeitura sofreu resistência por parte dos moradores da região, que criaram a associação Defenda a Barra Funda. Essa associação, criada para combater o Projeto Boracea, temia que houvesse degradação da área como decorrência da instalação do serviço. Além da associação de moradores, ao lado do Projeto, a empresa Klabin Segall estava construindo um empreendimento com 4 torres, com um total de 400 apartamentos. Segundo Sérgio Segall, diretor da Klabin Segall, "em um primeiro momento, foi anunciado um albergue com um sopão. Isso causou uma grande confusão. A prefeitura foi obrigada a conversar e ceder. Hoje, o governo municipal tem o compromissos de transformar aquilo em um projetomodelo ${ }^{, 293}$.

Após uma série de negociações com a Prefeitura, o Projeto passou a ser aceito pela comunidade. Dentre as concessões feitas pela Prefeitura, estavam a entrada do Projeto que, por exigência da associação dos moradores, deveria ser feita de modo a diminuir a circulação de pessoas de rua pela região; a instalação de uma base da Polícia Militar dentro do espaço do Projeto; e a criação de um centro comunitário da associação de moradores, também a ser mantida dentro do Projeto. ${ }^{294}$

Percebe-se a problemática situação em que se encontrou o Projeto: a fim de ser

293 SP vai atender catador e seu melhor amigo. Folha de São Paulo. 15/12/2002.

294 SP vai atender catador e seu melhor amigo. Folha de São Paulo. 15/12/2002. 
aceito, não só teve de alterar aspectos arquitetônicos por motivos, no mínimo, questionáveis, como teve de aquiescer com a presença de uma base da Polícia Militar, instalada dentro do espaço reservado aos serviços assistenciais.

\subsection{As entidades conveniadas}

Como já mencionados em outros capítulos desse trabalho, os serviços sócio assistenciais podem ser prestados diretamente por parte do poder público ou por intermédio de entidades conveniadas. No caso do Projeto Oficina Boracea, os serviços eram prestados em sua totalidade por entidades sem fins lucrativos, sendo que para tanto foram celebrados diversos convênios. Nessa parte do trabalho, serão analisados a totalidade dos convênios celebrados entre as entidades sem fins lucrativos e a Prefeitura de São Paulo/SMADS.

Contudo, antes de analisar os convênios é necessário fazer uma ressalva. Durante a pesquisa, o acesso a informações e documentos públicos em geral foi dificultado em decorrência da falta de sistematização e publicização de dados públicos da própria Secretaria de Assistência Social. O espaço destinado para o arquivamento e manutenção dos documentos públicos da SMADS era incompleto e defasado. ${ }^{295}$ Ademais, em contato com funcionários da Prefeitura, alguns dados requeridos, referentes a processos administrativos, foram ditos serem sigilosos.

Assim, tendo em vista essa dificuldade inicial, e sabendo ainda que todos os editais para celebração de convênio, pareceres sobre as propostas das associações, convênios celebrados e seus aditamentos são publicados no Diário Oficial da Cidade de São Paulo, tratando-se ainda de uma fonte oficial, os dados publicados nesse meio foram utilizados como uma importante fonte de informação quanto aos convênios celebrados, serviços ofertados e associações envolvidas tanto relativos ao Projeto Boracea, como em referência a informações ligadas à rede de atendimento de serviços sócio assistenciais voltada à população em situação de rua na cidade de São Paulo.

\subsubsection{Fase inicial: os convênios celebrados entre 2003-2006}

Entre os anos de 2003-2006, os serviços prestados dentro Complexo Boracea

295 Foram consultados os arquivos do Centro do Conhecimento da Assistência Social (CECOAS) do Espaço Público do Aprender Social (ESPASO)/SMADS. 
contaram com a participação de diversas entidades, sendo que cada uma era voltada para a prestação de um ou mais serviços específicos: Centro de Acolhida, Restaurante Escola Oficina Boracea, Núcleo de Atendimento de Catadores, Núcleo de Atendimento e Trabalho Sócio Educativo com Famílias, Serviço de Apoio Sócio Educativo de capacitação e orientação profissional, Abrigo Especial para Idosos-Projeto Oficina Boracea e Lavanderia - Escola Oficina Boracea.

Dentre as atividades previstas, podemos citar pormenorizadamente as seguintes: ${ }^{296}$

(i) Atividades socioeducativas: oficinas de leitura e de alfabetização;

(ii) Atividades de lazer: cinema, música e dança, oficinas de artes plásticas, ginástica e esportes e rádio comunitária;

(iii) Geração de renda: oficinas de produção de objetos com materiais recicláveis, loja social, galpão de separação e pesagem de materiais recicláveis, venda de materiais recicláveis;

(iv) Ligação com a comunidade: apresentações culturais e telecentro.

(v) Serviços em geral: providenciar documentos e localização da família dos usuários.

Nos primeiros 3 anos, sete entidades atuaram dentro do Complexo: (i) Assistência Social Lar Ditoso; (ii) Ação Ética e Cidadania; (iii) Instituto Lygia Jardim; (iv) Coordenação Regional das Obras de Proteção Humana; (v) Serviço Promocional e Social da Paróquia de Santa Cecília; (vi) Centro de Educação, Estudos e Pesquisas e (vii) Associação Evangélica Beneficente.

A organização Assistência Social Lar Ditoso era responsável por dois serviços: Centro de Acolhida e Restaurante Escola. A Assistência Social Lar Ditoso era uma entidade de caráter religioso, fundada em 1978 por membros da $1^{\text {a }}$ Igreja Unidade de Guaianazes. A organização iniciou suas atividades fornecendo alimentação e atividades recreativas e esportivas para crianças no Bairro de Guaianazes, tendo se tornado parceira da Prefeitura de São Paulo em outubro de 2001. Em 2005, a associação contava com 7 projetos sociais, sendo 2 deles dentro do Complexo Boracea. ${ }^{297}$

O Centro de Acolhida coordenado pelo Lar Ditoso fornecia 340 vagas. ${ }^{298}$ Foram comuns os aditamentos a fim de aumentar o número de vagas em caráter de acolhida

\footnotetext{
296 SIMÕES, Janaína Machado. Projeto Oficina Boracea. p. 209.

297 Diário Oficial da Cidade de São Paulo, 22 de novembro de 2005, p. 21.

298 Serviço estabelecido por meio do Termo de Convênio 08/SAS/PR-RI/2003.
} 
emergencial $^{299}$, assim como a prorrogação do prazo de vigência dos termos de convênio. ${ }^{300}$ A capacidade do Centro de Acolhida chegou a 676, incluindo vagas para pernoite e camas auxiliares durante o período das frentes frias. ${ }^{301}$

A Associação Lar Ditoso também era responsável pelo Restaurante-Escola Oficina Boracea ${ }^{302}$, responsável pelo preparo mensal de 29.450 desjejuns/lanches e 62.000 refeições ${ }^{303}$, cujo convênio também sofreu alterações, sendo prorrogado até 30/06/2006 ${ }^{304}$, sendo também reduzida a quantidade de refeições mensais e o repasse mensal de verbas. ${ }^{305}$

A organização Ação Ética e Cidadania, organização não governamental fundada em $1999^{306}$, coordenava o Núcleo de Atendimento de Catadores (NAC), constituído pelos

299 Diário Oficial da Cidade de São Paulo, de 25 de junho de 2005, p. 22, Termo de aditamento, indicando o aumento de 425 vagas para acolhida em caráter emergencial, na ocorrência de frentes frias ou baixas temperaturas, no período entre 23/06/2005 e 30/09/2005, e o aumento do repasse em $\mathrm{R} \$ 2.380,00$ no mês de junho; $\mathrm{R} \$ 9.222,50$ no mês de julho; $\mathrm{R} \$ 9.222,50$ no mês de agosto e $\mathrm{R} \$ 8.925,00$ no mês de setembro, totalizando 29.750,00;

Diário Oficial da Cidade de São Paulo, de 6 de julho de 2005, p. 19, indicando o aumento de 85 vagas em caráter emergencial, no período entre 23/06/2005 e 30/09/2005, e o aumento do repasse em $\mathrm{R} \$$ 29.750,00;

Diário Oficial da Cidade de São Paulo, de 6 de agosto de 2005, p. 23, indicando o aumento de 65 vagas em caráter emergencial, no período entre 14/07/2005 e 30/09/2005, e o aumento do repasse em R\$ 17.972,50;

Diário Oficial da Cidade de São Paulo, de 18 de agosto de 2005, p. 17, autorizando o pagamento de indenização de R \$ 22.080,00, em vista de 160 atendimentos emergenciais realizados entre 01/11/2004 e 16/12/2004, sem aditamento formal.

Diário Oficial da Cidade de São Paulo, de 21 de junho de 2006, p. 18, autorizando o acréscimo de 100 vagas no período de 15/06/2006 a 30/06/2006, destinadas ao atendimento emergencial em decorrência de frentes frias, mediante o repasse de $\mathrm{R} \$ 7,00$ por pessoa acolhida/dia, totalizando $\mathrm{R} \$ 11.200,00$.

300 Diário Oficial do Município de São Paulo, de 27 de outubro de 2005, p. 22, indicando o aumento de 150 vagas para atendimento emergencial, mediante o custo de $\mathrm{R} \$ 3,50$ pessoa/dia; prorrogação de 6 meses, de 1/11/2005 a 31/03/2006; alteração do plano de trabalho para aumentar em 160 vagas a partir de 01/11/2005 e aumento de repasse de verba mensal de $\mathrm{R} \$ 12.992,38$, totalizando o valor de $\mathrm{R} \$ 59.129,29$. Diário Oficial da Cidade de São Paulo, de 14 de abril de 2006, p. 18, prorrogação do prazo de vigência até 30/06/2006, acréscimo de 50 vagas e valor de repasse em $\mathrm{R} \$ 4.054,11$, totalizando valor de repasse em R $\$ 65.800,00$.

301 SIMÕES, Janaína Machado. Projeto Oficina Boracea. p. 212.

302 Serviço estabelecido pelo Termo de Convênio 011/SAS-PR-PI/2003.

303 Diário Oficial do Município de São Paulo, de 4 de agosto de 2005, p. 4, por meio do Decreto n. 46.177, de 3 de agosto de 2005, foi aberto Crédito Adicional Suplementar de R\$187.735,80, para possibilitar a execução do Convênio Restaurante Escola - Oficina Boracea.

304 Diário Oficial do Município de São Paulo, de 18 de novembro de 2005, p. 22, indicando o repasse mensal ao serviço de $\mathrm{R} \$ 140.771,85$, prorrogado pelo termo de aditamento $1 / 2005$ para ter vigência de mais 5 meses, de 01/11/2005 até 31/03/2006, conforme Diário Oficial do Município, de 28 de outubro de 2005, p. 35, mantendo as demais condições pactuadas.

Diário Oficial da Cidade de São Paulo, $1^{\circ}$ de abril de 2006, p. 18-19, convênio prorrogado de 01/04/2006 a 30/06/2006.

305 Diário Oficial da Cidade de São Paulo, de 26 de abril de 2006, p. 16, com redução no total de ofertas para 1605 refeições/dia e do valor do repasse mensal para $\mathrm{R} \$ 73.707,16$. Por meio do Decreto $46.177 / 2005$, foi aberto crédito adicional para o Restaurante-Escola, no valor de R\$ $187.735,80$, de acordo com o Decreto $\mathrm{n}^{\circ} 46.177$, de 3 de agosto de 2004, publicado no Diário Oficial do Cidade de São Paulo, de 4 de agosto de 2005, p. 4.

306 http://acaoeticaecidadaniaong.blogspot.com.br/ 
serviços de estacionamento, abrigo e coleta seletiva. ${ }^{307}$ O NAC disponibilizava 100 vagas para catadores, 50 vagas para carroças e 30 para cães. Esse convênio foi prorrogado até $31 / 07 / 2006$, e também teve redução de repasse de verbas. ${ }^{308}$

O Centro de Educação Estudos e Pesquisas (CEEP) era responsável pela oferta de formação profissional e incentivo à economia solidária, com capacidade para 560 pessoas/mês. ${ }^{309}$ O CEEP é uma entidade voltada para o desenvolvimento de estudos e pesquisas no campo da educação, da formação profissional e da geração de renda desenvolvendo programas formativos e de profissionalização ${ }^{310}$. O convênio celebrado com o CEEP foi posteriormente substituído pelo convênio celebrado com a organização Lygia Jardim.

Após substituir a convênio de responsabilidade do CEEP, a organização Instituto Lygia Jardim tornou-se responsável por dois serviços: Núcleo de Atendimento e Trabalho Sócio Educativo com Famílias e o Serviço de Apoio Sócio Educativo de capacitação e orientação profissional - SACECOP. ${ }^{311}$ O Instituto Lygia Jardim já desenvolvia trabalhos com pessoas em situação de rua desde 1978, ano em que foi iniciado os trabalhos no Albergue Lygia Jardim. Após alguns anos, foi aberta a Casa de Recuperação, voltada para o tratamento de moradores de rua em estado pré ou pós cirúrgicos, ou em tratamento de doenças crônicas. Em 1999, em parceria com a Prefeitura de São Paulo, desenvolveu-se o SASECOP, um projeto de profissionalização e capacitação para a reintegração de pessoas excluídas no mercado de trabalho e na sociedade. ${ }^{312}$

O convênio para o Núcleo de Atendimento e para o SACECOP também foi alvo da prorrogação de prazo de vigência e número de vagas. O SACECOP prestava o serviço para 120 pessoas ao mês, tendo posteriormente sido reduzido o numero de vagas para 80

307 Serviço estabelecido por meio do Termo de Convênio 12/SAS/PR-RI/2003.

308 Diário Oficial do Município de São Paulo, de 4 de novembro de 2005, p. 36, com termo de aditamento para ter prorrogar a vigência do convênio de mais 5 meses, de 01/11/2005 até 31/03/2006, reduzindo o repasse de verbas para $\mathrm{R} \$ 18.393,45$, mantendo as demais condições pactuadas; Diário Oficial do Município de São Paulo, de 3 de dezembro de 2005, p. 27, Núcleo de Atendimento a Catadores, 100 vagas disponibilizadas. Prorrogação do prazo de vigência do convênio até 31/03/2006, reduzindo o repasse de verbas para R \$ 18.393,45; Diário Oficial da Cidade de São Paulo, 15 de junho de 2006, p. 15, prorrogação de prazo de vigência até 30/06/2006 e redução do valor de repasse mensal para R\$ 16.893,45; Diário Oficial da Cidade de São Paulo, 11 de julho de 2006, p. 18, prorrogação de prazo de vigência até 31/07/2006.

309 VICTORIANO, Eliana Fernandes Loureiro. Projeto Oficina Boracea. (...) p.63; PONTIFÍCIA UNIVERSIDADE CATÓLICA DE SÃO PAULO. INSTITUTO DE ESTUDOS ESPECIAIS. Cadernos 2. 2004, p. 25.

310 Diário Oficial do Município de São Paulo, de 9 de junho de 2006, p. 19; http://ceep.org.br/

311 Serviço estabelecido por meio do Termo de Convênio 409/SAS/2003.

312 http://www.asapam.org.br/Lygia_Jardim/ 
pessoas, além de haver a prorrogação do prazo de convênio. ${ }^{313}$

Associação Evangélica Beneficente (AEB) coordenava o Centro de Convívio, com capacidade para 200 pessoas ao mês, no qual eram ofertadas oficinas de diversas naturezas como artes plásticas, aulas de música, atividades esportivas, oficinas de comunicação e a programação de cinema, além de sala de TV, sala de leituras e brinquedoteca. ${ }^{314}$ A AEB era uma entidade atuante já há algum tempo dentro do universo da população de rua, tendo sido umas das primeiras organizações a ofertar o trabalho de Núcleo de Convivência (Porto Seguro), ainda na década de $80 .^{315}$

A organização Coordenação Regional das Obras de Proteção Humana - CROPH prestava o serviço de Abrigo Especial para Idosos. ${ }^{316}$ A CROPH foi criada em 1969, vinculada a obras assistenciais promovidas pela Igreja Católica na cidade de São Paulo. Sua primeira experiência com a população em situação de rua foi no gerenciamento do antigo CETREM. Ao longo do anos, celebrou diversos convênios com a Prefeitura de São Paulo para a prestação de serviços assistenciais. ${ }^{317}$

O Abrigo Especial para idosos era responsável pela acolhida de 50 idosos/mês de ambos os sexos. Além da acolhida, eram oferecidas atividades recreativas, sócioeducativas e acesso ao atendimento social buscando resgatar laços familiares, assim como a promoção de reuniões e assembleias estimulando o convívio social. ${ }^{318}$

313 No que toca ao Núcleo de Atendimento e Trabalho Sócio Educativo com Famílias, houve termo de aditamento para prorrogar a prestação do serviço por mais 5 meses, de 01/11/2005 até 31/03/2006, mantendo as demais condições pactuadas conforme consta no Diário Oficial do Município de São Paulo, de 7 de outubro de 2005, p. 34. No Diário Oficial do Município de São Paulo, de 19 de abril de 2006, p. 19, constou prorrogação do prazo de vigência até 30/06/2006. Ainda, houve alteração do prazo de vigência do convênio até 31/12/2006, com redução em 40 vagas, totalizando 80 vagas de atendimento, sem redução do valor de repasse, conforme Diário Oficial da Cidade de São Paulo, de 4 de julho de 2006, p. 16.

No que toca ao Serviço de Apoio Sócio Educativo de capacitação e orientação profissional, houve alteração do local de prestação do serviço, alteração do repasse de verbas para R \$17.400,60 e alteração do prazo do convênio até 31/10/2005, conforme o Diário Oficial do Município, de 20 de maio de 2005, p. 15, de 8 de junho de 2005, p. 27 e 18 de novembro de 2005, p. 25.

314 VICTORIANO, Eliana Fernandes Loureiro. Projeto Oficina Boracea. (...) p.62; PONTIFÍCIA UNIVERSIDADE CATÓLICA DE SÃO PAULO. INSTITUTO DE ESTUDOS ESPECIAIS. Cadernos 2. 2004, p. 25.

315 A AEB foi fundada em 1928, tendo por objetivo inicial socorrer especialmente os membros das igrejas evangélicas em escassez de recursos problemas de saúde (tuberculose). Com o passar do tempo, a AEB expandiu seu trabalho da AEB para outras áreas assistenciais, com crianças órfãs, e posteriormente, com idosos. No entanto seus projetos foram se diversificando, e na década de 80 , os novos desafios decorrentes da redemocratização desafiaram a AEB a repensar o sentido e a forma de fazer a ação social. Nesta nova linha de trabalho, a AEB criou a Casa Porto Seguro, projeto destinado ao atendimento de homens em situação de rua no Centro de São Paulo. http://aeb-brasil.org.br/ Serviço estabelecido pelo Termo de Convênio 007/SAS-PR-PI/2003.

317 Diário Oficial da Cidade de São Paulo, de 21 de fevereiro de 2013, p. 55.

318 VICTORIANO, Eliana Fernandes Loureiro. Projeto Oficina Boracea. (...) p.62. 
O convênio celebrado com a CROPH foi aditado para alterar o número de vagas e reduzir repasse de verba. ${ }^{319}$ Houve também alteração do termo de vigência. ${ }^{320}$

A Lavanderia - Escola Oficina Boracea ${ }^{321}$ era voltada para a formação de 20 alunos por curso, cujo convênio era formado com a organização Serviço Promocional e Social da Paróquia de Santa Cecília (SPES). A SPES era uma entidade sem fins lucrativos criada em 1969, com objetivo de atuar na área de Assistência Social e auxiliar a promoção das famílias carentes da região da Santa Cecília ${ }^{322}$.

A Lavanderia-Escola estimulava oficinas de qualificação em trabalho especializado na área da lavanderia industrial, auxiliares de limpeza e arrumadeiras, com capacidade para 50 pessoas/mês, com uma bolsa no valor de $\mathrm{R} \$ 100,00$, como incentivo à autonomia. Existia ainda a perspectiva que após a formação, os alunos pudessem desenvolver atividades em hotéis, lavanderias e hospitais ${ }^{323}$.

O convênio com a SPES sofreu vários aditamentos, além de redução de repasse de verba $^{324}$

Além das entidades conveniadas, o Projeto contava com parceiros dentro da sociedade civil e do governo: ${ }^{325}$

(i) O Centro de Estudos e Pesquisas sobre pessoas em situação de rua coordenava grupos de reflexão sobre a questão dos moradores de rua, além de realizar a análise de sistematizações e avaliações que eram feitas no Projeto.

319 Diário Oficial do Município de São Paulo, de 20 de julho de 2005, p. 19, de 9 de julho de 2005, p. 16, no aditamento 1/2005, indicando o aumento do número de vagas para 70 pessoas com mais de 60 anos, além da redução do repasse para $\mathrm{R} \$ 13.205,94$.

Diário Oficial da Cidade de São Paulo, $1^{\circ}$ de abril de 2006, p. 19, convênio prorrogado de 01/04/2006 a 30/06/2006, com repasse mensal de $\mathrm{R} \$ 13.866,24$.

Diário Oficial do Município de São Paulo, de 12 de julho de 2006, p. 18, indicando a prorrogação do convênio até 31/07/2006.

320 Diário Oficial do Município, de 3 de dezembro de 2005, p. 27, pelo aditamento 2/2005, alterou o prazo de pagamento e a vigência do convênio por mais 5 meses, de 1/11/2005 a 31/03/2006.

321 Serviço estabelecido por meio do Termo de Convênio 547/SAS/2003.

322 http://ccasaojose.org.br/

323 VICTORIANO, Eliana Fernandes Loureiro. Projeto Oficina Boracea. (...) p.63.

324 Diário Oficial da Cidade de São Paulo, de 19 de novembro de 2005, p. 26, prorrogando o prazo de vigência de 01/12/2005 até 31/03/2006 e reduzindo o repasse mensal de verbas para $\mathrm{R} \$ 33.517,49$.

Diário Oficial do Município, de 3 de dezembro de 2005, p. 29, pelo aditamento 1/2005, alterou o prazo de pagamento e a vigência do convênio até 30/11/2005. Dotação orçamentária de 33.517,49, para lavagem de 17.600 quilos de roupa/mês

Diário Oficial da Cidade de São Paulo, de $1^{\circ}$ de abril de 2006, p. 19, convênio prorrogado de 01/04/2006 a 30/06/2006.

Diário Oficial da Cidade de São Paulo, 27 de julho de 2006, p. 15, convênio prorrogado até 31/07/2006.

325 PONTIFÍCIA UNIVERSIDADE CATÓLICA DE SÃO PAULO. INSTITUTO DE ESTUDOS ESPECIAIS. Cadernos 2. 2004, p. 22-25. 
(ii) O Centro de Saúde Escola Dr. Alexandre Wranjac (Barra Funda) fazia o acompanhamento de problemas de saúde, realizando atendimento ambulatorial dentro e fora do projeto. No Boracea, também havia um agente comunitário de saúde, que auxiliava as pessoas a utilizar a rede municipal de saúde.

(iii) O Centro Esportivo Raul Tabajara, situado ao lado do Projeto, permitia o acesso dos usuários do Projeto para atividades esportivas, principalmente na utilização de piscina e quadra de esportes.

(iv) O Centro Universitário Nove de Julho (UNINOVE) oferecia cursos de alfabetização de adultos dentro do espaço do Projeto.

(v) A Faculdade de Veterinária da Universidade de Santo Amaro (UNISA) era responsável pela supervisão do canil e orientação dos catadores (proprietários dos animais) em relação aos cuidados com a saúde dos animais.

(vi) A Caixa Econômica Federal mantinha um Posto de Atendimento Bancário dentro do Projeto, facilitando o acesso dos usuários do Projeto.

(vii) Foram realizadas também diversas parcerias com as seguintes Secretarias Municipais: Secretaria Municipal da Saúde, Secretaria Municipal de Obra e Serviços (Departamento de Resíduos Sólidos); Secretaria do Trabalho, Desenvolvimento e Solidariedade; Secretaria Municipal de Abastecimento; Secretaria Municipal de Comunicação e Informação Social; Secretaria Municipal da Cultura.

O Projeto também contava com o apoio de algumas empresas, que forneceram equipamentos, insumos e outros materiais. ${ }^{326}$

Nota-se, portanto, que o Projeto Boracea era integrado por uma série de serviços, dentre eles cursos e capacitação profissional, tendo por foco a reinserção social e a autonomia das pessoas em situação de rua. A estrutura de serviços criada, ao menos em seu aspecto institucional, era se afastar dos centros de acolhida que somente forneciam

326 Dentre as empresas que colaboraram com o Projeto, podemos citar: PHILIPS/WALITA, Embalagens SOL Ltda, Vision Systems, Multibrás, Banco Santander/Banespa, Estre Ltda, Novartis Biociências S/A, Sadia S/A, Natura S/A, Serasa S/A, Empresa Brasileira de Correios e Telégrafos, Sofá \& Cia. Ltda, Parmalat, Telefônica, Grupo Votorantin, SESC, Klabin Segall Empreendimentos, PNBE e Metalúrgica Ricci. In: VICTORIANO, Eliana Fernandes Loureiro. Projeto Oficina Boracea. (...) p.66; PONTIFÍCIA UNIVERSIDADE CATÓLICA DE SÃO PAULO. INSTITUTO DE ESTUDOS ESPECIAIS. Cadernos 2. 2004, p. 25-26. 
alimentação e pernoite, e sim criar um equipamento com uma grande diversidade de serviços e parceiros, buscando inovar em termos de política pública assistencial.

No que toca à gestão, o Projeto Oficina Boracea também foi inovador, pois pela primeira um projeto teve o poder público e entidades conveniadas num mesmo local decidindo e supervisionando conjuntamente a prestação de serviços, assim como seus custos. $^{327}$

Outro diferencial no que toca à gestão do serviço, e também algo pouco comum, era o diálogo no estabelecimento de regras e normas de convivência entre os usuários e coordenação do Projeto. Havia grande espaço para a manifestação de ideias, sugestões e críticas, sendo que muitas das ações em funcionamento decorriam de espaços propiciados à participação dos próprios usuários. ${ }^{328}$

Ademais, os coordenadores estimulavam os usuários a desenvolverem planos de vida. Retomando a ideia de efetivamente reconstruir vidas, explicavam que para conseguir sair das ruas, era necessário ir atrás das oportunidades, não ficarem somente parados, "vendo televisão". Com o sentido de concretizar essa ideia, os usuários, ao chegarem ao Projeto, tinha o prazo de um mês para planejar suas propostas, que seriam então apresentadas e discutidas. ${ }^{329}$

Após sua inauguração, o início do funcionamento do Projeto ocorreu ainda durante a gestão da Prefeita Marta Suplicy, tendo como Secretária a Assistência Social Aldaíza Sposati. Depois da mudança no executivo municipal, houve alteração tanto do prefeito como do Secretário da Assistência: José Serra se tornou Prefeito e Floriano Pesaro assumiu o posto de Secretário.

Mesmo com essa alteração quanto ao executivo, em abril de 2005, o modelo aplicado pelo Boracea era avaliado positivamente pela Secretaria Municipal de Assistência Social, devido ao duplo papel desenvolvido pelo Projeto, em acolher e capacitar a população em situação de rua. Naquela época, a capacidade do serviço era para o atendimento de 580 pessoas por dia, sendo 340 vagas no albergue, 120 atendimentos para cursos de capacitação, 50 vagas para idosos, além do Restaurante e Lavanderia-Escola (com curso de capacitação profissional para 20 albergardos). Além disso, o Núcleo de

327 VICTORIANO, Eliana Fernandes Loureiro. Projeto Oficina Boracea. (...) p.72.

328 LAVARELLO, Fernanda Bastos. Pessoas em situação de rua: análise psicossocial de uma intervenção no Projeto Oficina Boracea. Tese de Conclusão de Curso. Pontifícia Universidade Católica. 2004. Pp.32-33.

329 LAVARELLO, Fernanda Bastos. Pessoas em situação de rua: análise psicossocial de uma intervenção no Projeto Oficina Boracea. (...) p.32. 
Atendimento catadores disponibilizava 70 vagas para catadores de materiais recicláveis, 100 vagas para carrinhos e 30 boxes para animais de estimação. ${ }^{330}$

Em agosto de 2005, a Secretaria manifestava sua intenção em expandir o modelo utilizado pela Oficina Boracea, mas utilizando unidade menores, para o atendimento de 100 pessoas. Manter-se-ia, contudo, o foco do Projeto, buscando a reinserção das pessoas em situação de rua através da capacitação e revalorização dos indivíduos. Reconhecia-se que o diferencial do Complexo eram os serviços voltados especificamente para os catadores de materiais. $^{331}$

Em outubro de $2005^{332}$, Floriano Pesaro informou suas intenções em reformular o sistema de albergues. Dentre as primeiras ações de reestruturação, estava a transferência de dois albergues, Portal do Futuro e Espaço Luz, para estruturas menores e mais bem equipadas. Ademais, tinha-se por objetivo flexibilizar as regras de funcionamento dentro dos albergues, com o fim de obter um aumento nos índices de acolhida.

Dentre os equipamentos que também passariam por uma reestruturação, encontrava-se a Oficina Boracea. De acordo com o Secretário, “o Boracea também será reestruturado, pois o atendimento lá é muito volumoso, com cerca de 1.000 atendimentos por dia. Vamos fazer equipamentos menores para melhor atender a população em situação de rua. O Oficina.Boracea não será desativado, mas reestruturado". A ideia por trás de criar equipamentos menores era fornecer atendimento mais personalizado.

Todavia, em pese as intenções veiculadas pelo novo Secretário no sentido de somente diminuir o tamanho do Projeto, mas manter o foco na reinserção social, a partir de certo momento, as características do Oficina Boracea começaram a se modificar. Com as alterações iniciadas entre os anos de 2005/2006, pode-se dizer que o serviço passou a se tornar mais um centro de acolhimento, garantindo a entrada dos usuários, mas sem garantir que estes saíssem e se tornassem pessoas autônomas. ${ }^{333}$

As primeiras modificações ocorreram em relação às entidades AEB e CEEP. O primeiro convênio não renovado foi o da $\mathrm{AEB}$, responsável pelo Centro de Convívio. Posteriormente, não foi renovado o convênio celebrado com o CEEP, responsável pela

330 Oficina.Boracea, o caminho de volta para casa. Diário Oficial do Município, de 30 de abril de 2005, p. II. Notícias.

331 Oficina.Boracea. Um albergue com banco e telecentro. Diário Oficial do Município, de 6 de outubro de 2005, p. II. Notícias

332 Novos albergues terão atendimento personalizado e regras flexíveis. Diário Oficial do Município, de 6 de outubro de 2005, p. II. Notícias.

333 VICTORIANO, Eliana Fernandes Loureiro. Projeto Oficina Boracea. (...) p.71. 
formação profissional e incentivo à economia solidária. Em seu lugar, novo convênio foi celebrado, com o Instituto Lygia Jardim - SASECOP, que embora tivesse cursos profissionalizantes, não trabalhava a questão do incentivo à economia solidária, mudando o perfil dos cursos ali existentes. Ademais, nota-se que em relação aos cursos do CEEP, os usuários recebiam uma bolsa para contribuir para sua autonomia, o que não ocorria com o SASECOP. $^{334}$

Em seguida, mesmo avaliando positivamente o foco do Complexo, voltado para a reinserção dos moradores de rua, em meados de 2006, a Secretaria anunciou sua intenção de fechamento do Núcleo de Catadores. A ideia era desativar esse Núcleo até o final de junho de 2006, vinculando as atividades de coleta de materiais não mais sob a responsabilidade da Secretaria de Assistência e Desenvolvimento Social, e sim sob a Secretaria de Serviços. Durante a transição, seriam indicados locais provisórios para que os catadores pudessem continuar os trabalhos de coleta e de seleção de material, sem que se prejudicasse suas atividades. $^{335}$

No que toca à gestão do Projeto, como se verá em seguida, após um período inicial de gestão diferenciada, onde diversas entidades trabalhavam conjuntamente, de forma mista, a Secretaria de Assistência Social decidiu pela celebração de convênio com somente uma entidade. Alterou também a forma de participação do poder público, pois determinou que o representante da Secretaria somente supervisionasse o Projeto, sem participar diretamente da coordenação das atividades cotidianas.

Dessa forma, após a instalação de um modelo que, por sua formulação e ideologia, buscava prestar serviços diversificados com foco na geração da autonomia e reinserção social, já no período 2005-2006 foi possível se vislumbrar o início de grandes alterações do Projeto, como a retirada do Núcleo de Catadores, a mudança no tipo de gestão e a transformação quanto aos tipos de cursos profissionalizantes oferecidos. No futuro, essas alterações continuaram, e consolidaram a modificação do perfil do Projeto, que se tornou cada vez mais acomodativo.

\subsubsection{6-2007: Instituto Cireneu}

Nessa parte, será possível vislumbrar o processo de centralização dos serviços

\footnotetext{
334 VICTORIANO, Eliana Fernandes Loureiro. Projeto Oficina Boracea. (...) p.71.

335 Carroceiros do Boracea acietam a proposta da Secretaria de Serviços. Diário Oficial da Cidade de São Paulo, 11 de maio de 2006.
} 
prestados no Projeto, assim como a continuação no que toca às transformações no perfil do Projeto.

Com o objetivo de centralizar a prestação dos serviços nas mãos de somente uma organização, em 4 de julho de $2006^{336}$, foi celebrado o Convênio 67/SMADS/2006 com o Instituto Cireneu, para a realização de serviço de Núcleo de Albergue e Restaurante Comunitário - Oficina Boracea, abrangendo o oferecimento de 650 (seiscentas e cinquenta) vagas de albergue e serviço de restaurante comunitário, para 720 cafés da manhã, 300 almoços, 140 cafés da tarde, 720 jantares, 75 mamadeiras. Esse convênio era de caráter emergencial e teria vigência de somente um mês: de 01/07/2006 a 31/07/2006.

A fim de regularizar a prestação de serviços no Complexo Boracea, em 20 de junho de 2006, foi lançado o edital 18/2006/SMADS ${ }^{337}$, tornando pública a instalação do serviços de assistência social Oficina Boracea, e convidando as organizações e entidades sem fins lucrativos interessadas no estabelecimento de parceria para a apresentação de propostas.

Em 3 de julho de 2006, ${ }^{338}$ realizou-se a audiência pública referente ao Edital 18/2006 SMADS, tendo três associações apresentado propostas para celebração do convênio: Associação Internacional para o Desenvolvimento - ASSINDES, Instituto Cireneu e Assistência Social Lar Ditoso, sendo o Instituto Cireneu considerado a organização mais apta para a celebração do convênio.

Em $1^{\mathrm{o}}$ de agosto de $2006^{339}$, foi homologado o convênio com a organização Instituto Cireneu, pelo Termo de Convênio no 75/SMADS/2006,

"Para a realização do Projeto Oficina Boracea, totalizando 1000 (mil) vagas $^{340}$, sendo 680 (seiscentas e oitenta) vagas para abrigamento/albergamento, das quais 500 (quinhentas) para albergamento de pessoas adultas em situação de rua, 110 (cento e dez)

336 Diário Oficial da Cidade de São Paulo, em 11 de julho de 2006, p.18, instituindo repasse total de R\$ 203.411,28, após assinatura do convênio, para o atendimento das despesas iniciais e o valor restante de $\mathrm{R} \$ 142.387,90$, após a devida prestação de contas.

337 Em 17 de maio de 2006, conforme Diário Oficial do Município, p. 58/59, a Secretaria Municipal de Assistência Social tornou público o Edital de chamamento para celebração de convênio Oficina Boracea (Edital no 013/2006/SMADS). Em 30 de maio de 2006, foram apresentadas propostas de duas organizações: Associação Internacional para o desenvolvimento e Assistência Social Lar Ditoso. Contudo, conforme consta no Diário Oficial do Município, de 8 de junho de 2006, p. 21, o Comitê Técnico de Avaliação julgou que ambas propostas não contemplavam as exigências necessária para a celebração do convênio, tendo sido necessário novo chamamento, feito por meio do Edital $\mathrm{n}^{\circ}$ 18/2006/SMADS, publicado no Diário Oficial da Cidade de São Paulo em 20 de julho de 2006, p. 90/91.

338 Diário Oficial do Município, de 8 de julho de 2006, p. 52-53.

339 Diário Oficial do Município, de $1^{\circ}$ de agosto de 2006, p. 11

340 As mil vagas mencionadas no convenio referem-se ao número de atendimentos a ser realizado durante o mês. 
vagas/noite para homens em situação de rua e 70 (setenta) para abrigamento para idosos em situação de rua; 320 (trezentas e vinte) vagas para o núcleo de inserção produtiva; estacionamento de 50 (cinquenta) carroças vazias; vagas para 30 (trinta) cães; atendimento social para 1000 (mil) pessoas em situação de rua usuários do serviço; operação de serviços de lavanderia e restaurante comunitário, mediante o repasse mensal de $R \$ 320.000,00$ (trezentos e vinte mil reais) e verba implantação no valor de $R \$ 180.000,00$ (cento e oitenta mil reais)."

O objetivo era que o convênio com o Instituto Cirineu tivesse prazo de vigência de $01 / 08 / 2006$ a $31 / 07 / 2009 .^{341}$

As intenções por parte da Secretaria de Assistência Social em centralizar os serviços mantiveram-se claras: dando continuidade ao convênio emergencial já celebrado com o Instituto Cirineu, foi lançado somente um edital, voltado para a prestação da totalidade de serviços dentro do Projeto.

Dessa forma, enquanto no período compreendido entre os anos de 2003 a 2006, diversas entidades trabalhavam em conjunto dentro do Projeto Boracea, a Secretaria de Assistência Social entendeu mais adequada a celebração de um convênio que reunisse, na medida do possível, todos os serviços a serem prestados. A avaliação do Secretário da Assistência da época era de que a dinâmica entre as associações que trabalhavam dentro do Projeto não era eficiente, decidindo-se centralizar a gestão do Projeto nas mãos de somente uma organização. ${ }^{342}$

Ademais, no que toca à gestão do Projeto, como já afirmando, buscou-se alterar o mecanismo de gestão mista. Nos primeiros três anos, o Projeto era coordenado por um órgão gestor, que abrangia tanto o poder público, como as diversas entidades conveniadas. Com a celebração do convênio com o Instituto Cirineu, essa forma de gestão mista foi alterada, fazendo com que somente a entidade conveniada coordenasse o Projeto, sem participação direta do poder público, mas sob a supervisão da SAS/Sé. ${ }^{343}$

Outra alteração que pode ser observada nesse momento foi a questão do Núcleo de Catadores. Em que pese ter-se mantido as vagas para carroças e cachorros, o Núcleo de Catadores foi efetivamente fechado.

341 Diário Oficial da Cidade de São Paulo, 11 de agosto de 2006, p. 16.

342 PESARO, Floriano. O Futuro no presente. Por uma São Paulo mais humana e participativa. Editora Gente. São Paulo, 2008. P. 183-186.

343 VICTORIANO, Eliana Fernandes Loureiro. Projeto Oficina Boracea. (...) p.71. 
Houve também alteração quanto ao tipo de serviços fornecido no que toca à capacitação profissional. Como já fora mencionado acima, os convênios com as organizações CEEP e AEB não foram renovados. A não renovação do convênio com o CEEP representou uma grande perda, tendo em vista se tratar de um serviço para formação profissional e incentivo à economia solidária. $\mathrm{O}$ convênio que o substituiu, celebrado com a organização Lygia Jardim, deu continuidade ao atendimento sócio educativo com famílias e a capacitação e orientação profissional. Contudo, tendo em vista a celebração do convênio com o Instituto Cirineu, não houve continuidade dos serviços prestados também pela associação Lygia Jardim. Essa descontinuidade na prestação de serviço, por duas oportunidades em tão curto período de tempo, se mostrou prejudicial.

Algo semelhante pode ser dito quanto ao convênio celebrado com AEB, que coordenava o Centro de Convívio, e que não foi renovado. Com o convênio celebrado com o instituto Cirineu, sequer houve previsão desse serviço.

Todavia, no novo convênio, houve, ao menos, a previsão do serviço de Núcleo de Inserção Produtiva, para 320 pessoas, ou seja, houve a manutenção de algum tipo de serviço voltado para a capacitação profissional.

Com a celebração do Convênio com o Instituto Cirineu, a intenção era que este se prolongasse ao menos até Julho de 2009. Contudo, a gestão do Projeto feita pelo Instituto Cirineu apresentou diversos problemas, levando a rescisão do convênio.

Em 2007, o Projeto se encontrava sob uma situação considerada precária. O local estava descuidado e os usuários reclamavam da falta de higiene e da economia feita com produtos de limpeza, além de afirmarem que eram mal tratados pelos funcionários. Ademais, o perfil dos usuários havia se modificado: em vez de carroceiros, a maioria dos usuários era formado por deficientes físicos $-20 \%$ dos albergados - e pessoas com algum tipo de problema mental $-30 \%$ dos albergados. ${ }^{344}$

$\mathrm{Na}$ época, a Secretaria de Assistência Social informou que o número de denúncias contra o Projeto havia aumentado muito nos últimos tempos. A situação dos administradores que coordenavam o local tinha se tornado insustentável. A intenção da Secretaria era de transferir, a partir do dia 16 de outubro, a coordenação do Boracea para outra entidade, a associação APOIO. A coordenadora de proteção social especial e adulta, Simoni Piragine, afirmou que algumas atitudes estavam sendo tomadas para tentar salvar o

344 Oficina Boracea vira depósito de sem teto. Jornal da Tarde. 21/09/2007. 
Boracea, dentre elas a diminuição do números de albergados, de 600 para $400 .{ }^{345}$

Em 16 de outubro de 2007, o Convênio 75/SMADS/2006 celebrada entre Instituto Cireneu e SMADS/Prefeitura de São Paulo foi efetivamente rescindido. ${ }^{346}$

\subsubsection{7-2013: Associação APOIO}

Em face da rescisão contratual do convênio celebrado com o Instituto Cirineu, foi necessária a celebração de um convênio emergencial, a fim de se manter a prestação dos serviços no Complexo Boracea.

De início, nota-se que a SMADS manteve com a Associação APOIO a mesma estrutura de serviços que havia com o Instituto Cirineu. Será somente após o fim do convênio emergencial com a Associação APOIO que ocorrerão maiores mudanças na estrutura dos convênios celebrados.

Dessa forma, em outubro de 2007, foi autorizada a celebração de convênio, em caráter emergencial, com a Associação de Auxílio Mútuo da Região Leste - APOIO, pelo prazo de três meses, a começar em 01/10/07, sendo posteriormente prorrogado,

“abrangendo o total de 1000 (mil) vagas, sendo 500 (quinhentas) para albergamento de pessoas adultas em situação de rua, 110 vagas/noite para homens em situação de rua, 70 para idosos em situação de rua, 320 para o Núcleo de Inserção Produtiva, estacionamento para 50 carroças, atendimento social para 1000 pessoas, bem como operação de serviço de lavanderia social e do Restaurante Comunitário, mediante o repasse de $R \$ 320.000,00 ., 347$

A entidade escolhida para a celebração do convênio emergencial é uma associação civil, sem fins lucrativos fundada em 1993. A Associação APOIO iniciou suas atividades auxiliando famílias em situação de risco que viviam em cortiços e favelas. Posteriormente,

345 Oficina Boracea vira depósito de sem teto. Jornal da Tarde. 21/09/2007.

346 Diário Oficial da Cidade de São Paulo, $1^{\circ}$ de novembro de 2007, p. 16 e Diário Oficial da Cidade de São Paulo, de 19 de outubro de 2007, p. 18.

347 Convênio emergencial 86/SMADS/2007, publicado no Diário Oficial da Cidade de São Paulo, de 4 de outubro de 2007, p. 10. O convênio emergencial foi prorrogado até 28/03/2008, até que fosse regularizada a prestação de serviços, de acordo com Diário Oficial da Cidade de São Paulo, de 7 de novembro de 2007, p. 26, prorrogação do Termo de Convênio 86/SMADS/2007 até 28/03/2008, com valor de repasse mensal de $\mathrm{R} \$ 331.968,00$, conforme valor reajustado constante no Diário Oficial de Cidade de São Paulo, de 30 de novembro de 2007, p. 19; Diário Oficial da Cidade de São Paulo, de 12 de dezembro de 2007, acréscimo de repasse mensal em $\mathrm{R} \$ 19.628,66$, totalizando o valor de $\mathrm{R} \$ 355.628,66$. Em fevereiro de 2008, o valor foi novamente reajustado para R\$359.948,02, de acordo com o Diário Oficial da Cidade de São Paulo, de 26 de fevereiro de 2008, p. 17. 
estendeu sua atuação para o segmento da população em situação de rua. Trabalhou com a Secretaria Municipal da Assistência Social nos programas Acolher e São Paulo Protege, em parcerias com a Prefeitura de São Paulo, e também em parceria com a Prefeitura de Santo André. Na época, era responsável por diversos programas ligados à Prefeitura de São Paulo. $^{348}$

Com o objetivo de regularizar a prestação de serviços, em 12 de fevereiro de 2008, foram lançados os Editais $n^{\circ}$ 11/2008/SMADS e $n^{\circ}$ 12/2008/SMADS, para que fossem apresentadas propostas pelas associações interessadas. ${ }^{349}$

Com os dois primeiros editais lançados, já se percebe o início das alterações no que toca aos serviços prestados: os editais previram, basicamente, serviços de acolhida, incluindo um serviço novo, a acolhida de pessoas convalescentes. Além disso, foram previstos os serviços de restaurante, lavanderia e atendimento diário, já existentes desde o início do Projeto. Observa-se ainda que não houve a previsão de nenhum serviço voltado especificamente para convivência ou mesmo para capacitação profissional.

Nesse sentido, o Edital no 11/2008/SMADS tinha por objeto a prestação do serviço de Centro de Acolhida Especial para 80 pessoas, sendo 50 homens e 30 mulheres em situação de rua e em período de convalescença, após alta hospitalar recebida da rede pública de saúde.

Já o Edital nº 12/2008/SMADS tinha por objeto a prestação de dois serviços de acolhida, com total de 380 vagas, divididas da seguinte forma: (i) Centro de Acolhida para Adultos II 24 horas, disponibilizando 320 vagas, 300 para homens e 20 para mulher; e (ii) Centro de Acolhida Especial para Idosos em Situação de Rua, disponibilizando 60 vagas, para ambos os sexos. Além disso, o convênio previa a prestação do serviço de lavanderia (no complexo e para os serviços localizados na Subprefeitura da Sé) e restaurante, com atendimento a 460 pessoas.

Nos dias 3 e 4 de março de $2008^{350}$, foram dados os pareceres técnicos, respectivamente, em referência aos Editais $n^{\circ}$ 11/2008/SMADS e nº 12/2008/SMADS. Em relação aos dois editais, houve somente uma proposta apresentada, pela Associação

\footnotetext{
348 Repúblicas para homens, Centro de Acolhida para Adultos Espaço Luz (Subprefeitura da Sé), Centro de Acolhida para Adultos Começar de Novo e Hotel Social (Subprefeitura da Penha), Centro de Acolhida para Adulto e Centro de Acolhida como Núcleo de Serviço Reencontro (Subprefeitura de Santo Amaro), Centro de Acolhida para Adultos Cancioneiros (Subprefeitura de Pinheiros), conforme consta no Diário Oficial da Cidade de São Paulo, de 6 de março de 2008, p. 66.

349 Diário Oficial da Cidade de São Paulo, de 12 de fevereiro de 2008, p. 53-56.

350 Diário Oficial do Município, de 8 de março de 2008, p. 65-66.
} 
APOIO, ${ }^{351}$ com quem a Secretaria de Assistência Social já havia celebrado os dois primeiros convênios. Ao final, os Pareceres Técnicos dos Comitês de Avaliação quanto às propostas da associação APOIO referente aos Editais 11 e 12 foram positivos, "destacando que a organização APOIO assumiu o serviço Oficina Boracea no período emergencial com responsabilidade e seriedade técnica, tendo revertido o quadro inicial encontrado quando da intervenção realizada pela SMADS”.

Como consequência foram celebrados dois Convênios entre a Prefeitura de São Paulo e APOIO: o Convênio 246/SMADS/2008, ${ }^{352}$ para o serviço de acolhida especial e atenção para adultos em situação de rua, com 80 vagas em período de convalescença; e o Convênio 247/SMADS/2008 353 , para o acolhimento de 380 pessoas em situação de rua, sendo 300 homens, 20 mulheres e 60 pessoas idosas, Lavanderia Social e Restaurante para atendimento de 460 pessoas/dia.

Até hoje, tanto o Convênio 246/SMADS/2008 como o Convênio 247/SMADS/2008 ainda se mantêm vigentes, com aumento de repasse de verbas. ${ }^{354}$

Após os dois convênios mencionados acima, foi lançado mais um edital, também para o serviços de acolhida, reiterando a alteração de perfil do Projeto Boracea.

Com o fim específico de atender a população de rua que vinha envelhecendo, foi lançado o Edital 5/2009/SMADS, para atender 100 idosos (homens e mulheres) em situação de rua. Quatro propostas foram apresentadas e, em 6 de maio de 2009, após avaliação das propostas e do parecer do Comitê de Avaliação ${ }^{355}$, em que pesem todas as entidades tenham sido consideradas como aptas, a associação Aliança da Misericórdia foi

351 Na época, essa associação era responsável pelo gerenciamento de diversos serviços conveniados com a Prefeitura de São Paulo, como o Centro de Acolhida para adultos Espaço Luz, Centro de Acolhida para adultos Começar de Novo, Hotel Social (Subprefeitura da Penha), Centro de Acolhida para adultos e Centro de Acolhida com Núcleo de serviços Reencontro (Subprefeitura de Santo Amaro), Centro de Acolhida para adultos Cancioneiro (Subprefeitura Pinheiros), e República para homens.

352 Diário Oficial do Município, 8 de abril de 2008, p. 26 e Diário Oficial da Cidade de São Paulo, de 19 de abril de 2009, p. 16, com repasse mensal de R\$ 69.930,17, com vigência de 29/03/2008 a 31/03/2010

353 Diário Oficial da Cidade de São Paulo, 8 de abril de 2008, p. 27 e Diário Oficial da Cidade de São Paulo, de 19 de abril de 2009, p. 16, com custo de R\$279.657,06, entre 29/03/2008 e 30/06/2008, e R\$ 239,407,06, a partir de 01/07/2008, com vigência de 29/03/2008 a 31/03/2010.

354 Convênio 246 e 247 com aumento de repasse mensal respectivamente de $\mathrm{R} \$ 105.069,65$ e $\mathrm{R} \$ 432.848,20$, até outubro de 2013. Houve aditamento temporário para o aumento do número de vagas no período de 01/11/2013 a 31/12/2013, em relação a ambos os convênios. Prorrogação dos convênio 246 e 247 até 28 de março de 2014, conforme consta no Diário Oficial da Cidade de São Paulo, de 19 de novembro de 2013, p. 16; valores de repasse e número de vagas previstos no Diário Oficial de 30 de outubro de 2013, p. 16; Aditamento para aumento temporário do número de vagas 80 vagas e repasse acrescido em $\mathrm{R} \$ 48.897,60$ no período, quanto ao convênio 247/SMADS/2008, e aumento de 5 vagas e repasse acrescido em R\$3.056,10 no período, quanto ao convênio 246/SMADS/2008, conforme consta no Diário Oficial da Cidade de São Paulo, de 7 de janeiro de 2014, p. 17.

355 Diário Oficial da Cidade de São Paulo, de 7 de maio de 2009, p. 68-69. 
entendida com abordagem mais diferenciada no que tocava ao tratamento da população de rua, sendo com ela celebrado novo convênio, que até hoje se mantém ${ }^{356}$. Desde 2007 , esse foi o único convênio celebrado com uma instituição que não fosse a Associação APOIO.

Durante todo o ano de 2009, foram celebrados quatro convênios em caráter emergencial, todos com a Associação APOIO. Os convênios foram celebrados em $\operatorname{março}^{357}$, junho $^{358}$, setembro ${ }^{359}$ e dezembro ${ }^{360}$ de 2009, para a prestação dos seguintes serviços: um Centro de Acolhida 24 horas, com 100 vagas, e três Centros de Acolhida I por 16 horas, dois com 200 vagas e outro com 160 vagas. Dispensou-se, excepcionalmente, o chamamento público tendo em vista a urgência da manutenção dos serviços, pois caso contrário, haveria prejuízo à população atendida.

A quantidade de convênios emergenciais celebrados em menos de um ano (março a dezembro de 2009) denota, no mínimo, falta de planejamento por parte da SMADS, tendo em vista ainda que todos os quatro convênios se referiam ao mesmo tipo de serviço (Centro de Acolhida). Ademais, reiterou-se o novo perfil do Projeto, que agora volta-se primordialmente para a acolhida.

Para a regularização dos serviços que estavam sendo prestados em caráter emergencial, tendo em vista os quatro convênios celebrados, foram lançados dois editais: Edital $n^{\circ}$ 217/SMADS/2010 e Edital no 219/SMADS/2010. Em 3 de novembro de 2010, houve reunião do Comitê de Avaliação quantos aos Editais n ${ }^{\circ} 217 / \operatorname{SMADS} / 2010$ e no 219/SMADS/2010.

356 Termo de Convênio 156/SMADS/2009, publicado no Diário Oficial da Cidade de São Paulo, de 10 de junho de 2009, p. 12 . O convênio previa repasse mensal de R \$ 58.805,07 e verba de implantação de R\$ 25.000,00, com vigência de 27/05/2009 a 26/05/2011. Até hoje o Termo de Convênio 156/SMADS/2009 se mantém com 100 vagas para idosos, tendo sido prorrogado até 26/05/2014, com repasse mensal atualizado no valor de $\mathrm{R} \$ 104.713,92$.

357 Termo de Convênio 139/SMADS/2009, para a prestação do serviço Centro de Acolhida para adultos II 24 horas, com 100 vagas a serem oferecidas e repasse mensal de $\mathrm{R} \$ 50.487,84$. O convênio teria vigência de 06/03/2009 a 01/09/2009.

358 Termo de Convênio 157/SMADS/2009, para a prestação do serviço de Centro de Acolhida para Adultos I por 16 horas, com total de 200 vagas para homens em situação de rua, vigência de 01/06/2009 a 01/12/2009, e repasse de R \$ 60.795,37, de acordo com o Diário Oficial da Cidade de São Paulo, de 11 de junho de 2009, p. 23; Diário Oficial da Cidade de São Paulo, de 6 de novembro de 2009, p. 13; Diário Oficial da Cidade de São Paulo, de 14 de novembro de 2009, p. 25.

359 Termo de Convênio 177/SMADS/2009, Diário Oficial da Cidade de São Paulo, de 22 de setembro de 2009 , p. 23, para a prestação do serviço de Centro de Acolhida para Adultos I por 16 horas, para 130 homens, com valor de repasse R\$ 57.071,05 mensal, com vigência de 02/09/2009 a 31/10/2009. Tal convênio foi aditado, com o fim de prorrogar o prazo de vigência até 31/01/2010, de acordo com Diário Oficial da Cidade de São Paulo, de 14 de novembro de 2009, p. 25.

360 Termo de Convênio 200/SMADS/2009, para prestação do serviço de Centro de Acolhida I por 16 horas, com 200 vagas para homens em situação de rua, com vigência para 02/12/2009 até 31/01/2010, e repasse mensal de R\$60.795,37, de acordo com Diário Oficial da Cidade de São Paulo, de 17 de dezembro de 2009, p. 19. 
Quanto ao edital $n^{\circ} 219^{361}$, para a prestação do serviço de Centro de Acolhida para Adultos II 24 horas, para 380 vagas para pessoas em situação de rua, sendo 300 vagas/noite e 80 vagas/dia para o Núcleo de Serviço, priorizando casos que de acordo com avaliação social demandassem atendimento integral. Somente houve inscrição da associação APOIO, tendo o parecer do comitê sido favorável para a celebração do convênio. Posteriormente, o convênio foi aditado para acrescer-se 100 vagas no que toca à acolhida e 70 vagas no que toca ao atendimento diário, além de aumentar o repasse de verbas. Esse Centro de Acolhida 24 horas passou a ser denominado Barra Funda II. ${ }^{362}$

Quanto ao Edital $n^{\circ} 217^{363}$, para a prestação do serviço de Centro de Acolhida para adultos I por 16 horas, para atendimento de 200 pessoas do sexo masculino, também houve somente proposta da Associação APOIO. O parecer final do Comitê foi, do mesmo modo, favorável à celebração do convênio, celebrado assim em novembro de 2010. O Serviço passou a ser conhecido como Centro de Acolhida Barra Funda I. ${ }^{364}$

O último convênio celebrado em relação ao Complexo Boracea referiu-se ao serviço de Atenção Urbana e Espaço de Convivência. Em outubro de 2010, foi publicado o

361 Diário Oficial da Cidade de São Paulo, de 4 de novembro de 2010, p. 64.

362 Termo de Convênio no 196/SMADS/2010, publicado no Diário Oficial da Cidade de São Paulo, de 11 de dezembro de 2010, p. 102, e Diário Oficial de Cidade de São Paulo, de 24 de dezembro de 2010, p.89 com valor inicial de repasse de $\mathrm{R} \$ 128.544,46$ e verba de implantação de $\mathrm{R} \$ 25.000,00$, com vigência de 04/12/2010 a 03/12/2012. Acréscimo de 100 vagas, totalizando 480 vagas, e readequação de repasse de verba de acordo com as portarias 46/SMADS/2010 e 47/SMADS/2010, sendo acrescido o repasse mensal de verbas em $\mathrm{R} \$ 28.347,18$, chegando a um total de repasse mensal de $\mathrm{R} \$ 156.891,18$, posteriormente aumentado para 164.42,12 de acordo com o Diário Oficial da Cidade de São Paulo, de 19 de julho de 2011, p. 62 e Diário Oficial da Cidade de São Paulo, de 5 de outubro de 2011, p. 87. Aumento de vagas de atendimento diário de 80 para 150, totalizando atendimento de 550, e aumento repasse de verbas em $\mathrm{R} \$ 174.587,37$, de acordo com o Diário Oficial da Cidade de São Paulo, de 4 de maio de 2012, p. 151.

Repasse de verbas atualizado para $\mathrm{R} \$ 220.434,03$, de acordo com o Diário Oficial da Cidade de São Paulo, de 30 de outubro de 2013, p. 16.

Convênio prorrogado até 03/12/2013, de acordo com o Diário Oficial da Cidade de São Paulo, de 22 de novembro de 2012, p. 95.

Convênio prorrogado até 3/12/2015, conforme Diário Oficial da Cidade de São Paulo, de 3 de dezembro de 2013, fl. 135.

Convênio aditado no período de 01/11/2013 a 31/12/2013 para acrescer 15 vagas e repasse aumentado em R\$ 9.168,30, de acordo com o Diário Oficial da Cidade de São Paulo, de 7 de janeiro de 2014, p. 59. Diário Oficial da Cidade de São Paulo, de 4 de novembro de 2010, p. 64-65.

364 Termo de Convênio 192/SMADS/2010, para 200 vagas masculinas, com repasse mensal de R 82.713,69 e verba de implantação de $\mathrm{R} \$ 18.000,00$, com vigência de 23/11/2010 a 22/11/2012, conforme consta no Diário Oficial da Cidade de São Paulo, de 16 de dezembro de 2010, p. 77.

Repasse de verbas atualizado para $\mathrm{R} \$ 102.420,42$, de acordo com o Diário Oficial da Cidade de São Paulo, de 30 de outubro de 2013, p. 16.

Convênio prorrogado até 22/11/2013, de acordo com o Diário Oficial da Cidade de São Paulo, de 6 de dezembro de 2012, p. 61, e posteriormente prorrogado até 22/11/2015, de acordo com o Diário Oficial da Cidade de São Paulo, de 11 de dezembro de 2013, p. 85. 
Edital de Convênio n ${ }^{\circ}$ 231/SMADS/2010 365 , para a seleção do serviço de Atenção Urbana Espaço de convivência Barra Funda I, para o atendimento de 200 pessoas por dia. Somente foi apresentada proposta pela associação APOIO, tendo sido julgada apta pelo comitêt ${ }^{366} \mathrm{e}$ em janeiro de 2011, foi celebrado o Convênio. Atualmente, o convênio ainda se mantém vigente, prestando serviço para 450 pessoas. ${ }^{367}$

Através dos serviços de Atenção Urbana e Espaço de Convivência, há o atendimento e o direcionamento das pessoas em situação de rua para serviços médicos, obtenção de documentos, encaminhamento para centros de serviços (onde há possibilidade de se obter refeições, lavar roupa ou tomar) e encaminhamento para centro de acolhida. Trata-se, portanto, de um serviço voltado meramente para as necessidades de subsistência das pessoas em situação de rua. Novamente, reiterou-se o novo perfil do Projeto, meramente acomodativo.

Em resumo: atualmente, o Complexo Boracea conta com seis convênios: (i) Centro de Acolhida Oficina Boracea, com 320 vagas para adultos, 60 vagas para idosos, Restaurante e Lavanderia; (ii) Centro de Acolhida para Pessoas em Convalescença, com 80 vagas; (iii) Centro de Acolhida II 24 horas com 400 vagas e Núcleo de Serviços para 150 vagas; (iv) Centro de Acolhida I 16 horas para 200 pessoas; (v) Espaço de Convivência Atenção Urbana, com 450 vagas diárias. (vi) Por fim, Centro de Acolhida para pessoas Idosas, com 100 vagas.

Os cinco primeiros convênios foram celebrados com a Associação APOIO e somente o último convênio foi celebrado com uma associação diversa.

Quanto aos convênios celebrados após 2007, alguns comentários podem ser feitos.

Primeiramente, no que toca à centralização dos serviços: pode-se notar que a SMADS manteve, indiretamente, a centralização da gestão em praticamente uma organização só. Com exceção de um único convênio celebrado com a Aliança da Misericórdia, que somente presta o serviço de acolhida de 100 idosos, os demais serviços são prestados pela organização APOIO.

Outro comentário importante refere-se a grande quantidade de convênios

365 Diário Oficial da Cidade de São Paulo, de 29 de outubro de 2010, p. 71.

366 Diário Oficial da Cidade de São Paulo, de 9 de dezembro de 2010, p. 69.

367 Termo de Convênio 30/SMADS/2011, publicado no Diário Oficial do Município de São Paulo, de 13 de janeiro de 2011, p. 62, para a prestação do serviço de atenção urbana, com repasse mensal de R\$ 45.251,34 e 200 vagas. De acordo com o Diário Oficial de 11 de dezembro de 2013, p. 85, houve aditamento do termo de convênio para aumentar o número de pessoas atendidas para 450, com aumento de repasse mensal em $\mathrm{R} \$ 35.311,66$. 
emergenciais: durante os primeiros dois anos em que a associação APOIO prestou serviços para a SMADS, foram celebrados cinco convênios emergenciais. Com exceção do primeiro convênio, que efetivamente foi celebrado em caráter emergencial, tendo em vista a rescisão um tanto quanto repentina do convênio anterior - celebrado com o Instituto Cirineu - os quatro convênios emergenciais celebrados em 2009 demonstraram no mínimo falta de organização por parte da SMADS, já que todos se referiam ao mesmo serviço (Centro de Acolhida).

No que toca especificamente aos serviços prestados, nota-se que o primeiro convênio, em caráter emergencial, celebrado em 2007 ainda previa, dentre outros serviços, 320 para o Núcleo de Inserção Produtiva e estacionamento para 50 carroças. Contudo, após a celebração dos novos convênios (de caráter não emergenciais) tais serviços não mais foram oferecidos. Tendo em vista que a escolha da quantidade e do tipo de serviços é feita pela própria SMADS, nota-se que o poder executivo na época optou pela retirada de mais um programa voltado para capacitação profissional, pois a partir de certo momento, o Núcleo de Inserção Produtiva deixou de existir.

No que toca ao serviço de acolhida, observa-se ainda que no período de conveniamento do Complexo Boracea com o Instituto Cirineu, o número de vagas para a acolhida era de 680. O objetivo da Secretaria em meados de 2006 era diminuir a capacidade do Projeto, o que realmente foi feito ${ }^{368}$ : os dois novos convênios assinados com a associação APOIO previam a acolhida de 460 pessoas, sendo 80 pessoas em situação de convalescença e 380 pessoas em situação de rua (300 homens, 20 mulheres e 60 idosos). Apesar de ainda ser um equipamento grande, a redução em 220 era representativa das intenções da SMADS em operar serviços com tamanhos menores.

Contudo, posteriormente, foram celebrados novos convênios, instituindo dois novos albergues (Barra Funda I e Barra Funda II), sendo todos administrados pela mesma associação - APOIO - e elevando o número de pessoas acolhidas a mais de 1000 vagas de acolhida.

Ademais, observa-se que, com exceção do Convênio celebrado com a associação Aliança da Misericórdia, para o serviço de acolhida de idosos, todos os demais convênios foram celebrados com a associação APOIO: centro de acolhida de adultos em período de convalescença; centro de acolhida para 380 pessoas em situação de rua, Lavanderia Social

368 PESARO, Floriano. O Futuro no presente. Por uma São Paulo mais humana e participativa. (...) pp. 186188. 
e Restaurante; Centro de Acolhida Barra Funda I e Barra Funda II e serviço de atenção urbana.

\subsection{Apontamentos finais}

Após a descrição da totalidade de serviços prestados e organizações que atuaram dentro do Projeto Oficina. Boracea, alguns apontamentos finais se fazem necessários.

Claramente, tendo em vista a complexidade do Projeto desenvolvido pela Secretaria de Assistência Social, assim como sua dimensão, além das diversas instituições conveniadas e a mudança no Poder Executivo (Prefeito e Secretário da Assistência Social), serão analisados alguns aspectos relevantes dentro do Complexo Boracea, tendo em vista tanto sua concepção original quanto as alterações ocorridas com o passar do tempo. A ideia, portanto, não é esgotar o tema no que toca os serviços da assistência social prestados entre 2003 e 2013 dentro do Projeto ou dentro da Secretaria de Assistência Social.

\subsubsection{Variedade de associações e gestão compartilhada}

$\mathrm{Na}$ fase inicial do Projeto Boracea, a gestão era mista, envolvendo tanto o poder público como uma grande variedade de associações privadas.

Ao mesmo tempo em que tal heterogeneidade poderia dificultar uma ação integrada, tendo em vista que cada associação estaria inclinada a atuar somente em seu núcleo, a gestão compartilhada permitia a troca de conhecimento entre as entidades, que contribuam de diversas formas, de modo a criar uma experiência gerencial mais rica. A coordenação do Projeto na época também era muito aberta à participação, buscando sua melhoria, sem perder o controle sobre as atividades a serem desempenhadas. ${ }^{369}$

No mais, as entidades vinculadas ao Projeto em seu início eram bem qualificadas, e desempenhavam suas funções de forma satisfatória. Infelizmente, a partir de 2006 e com a celebração de convênio único - inicialmente, com o Instituto Cirineu, e partir de 2007 com a associação APOIO - o mecanismo de gestão mista se perdeu, assim como a riqueza decorrente da combinação de diversas entidades. A opção da Secretaria de Assistência Social a partir de então foi manter somente uma organização responsável pelo

369 SIMÕES, Janaína Machado. Projeto Oficina Boracea. p. 213-214. 
gerenciamento do projeto, sem a intervenção direta do poder público, que somente supervisionaria o Projeto.

\subsubsection{Núcleo de Catadores}

A proposta inicial do Projeto Boracea era a busca da acolhida associada à autonomia. Dentro da busca pela autonomia, o incentivo aos catadores de materiais recicláveis era patente: na época somente um outro centro de acolhida - Dom Bosco contava com estrutura específica para abrigar o carroceiro e seu carrinho, e ainda não permitia a entrada de animais no local.

Dessa forma, a criação de um espaço que permitisse o contato do carroceiro com seu animal, associado ao fato de que no local havia a possibilidade de troca dos materiais coletados sem que houvesse intermediário - facilitando, portanto, a vida do catador apresentava-se como um ponto positivo, e um diferencial do Boracea.

Contudo, já desde meados de 2006, a SMADS anunciava sua intenção de fechar o Núcleo de Catadores, vinculando as atividades de coleta de materiais não mais sob a responsabilidade da Secretaria de Assistência e Desenvolvimento Social, e sim sob a Secretaria de Serviço.

No convênio celebrado com o Instituto Cirineu, ainda se previa estacionamento de 50 (cinquenta) carroças vazias; vagas para 30 (trinta) cães. O mesmo pode ser dito em relação ao Convênio Emergencial celebrado com a associação APOIO, que também previa o estacionamento de 50 (cinquenta) carroças, sem fazer previsão quanto aos cães. Entretanto, nos dois convênios celebrados em caráter permanente com a associação APOIO, ${ }^{370}$ já no ano de 2008, o Núcleo de Atendimento aos Catadores foi definitivamente retirado do Complexo Boracea.

A atividade dos catadores, além de ser uma forma de se obter renda, também era uma atividade importante ligada à autonomia e ao resgate da cidadania. Dessa forma, a catação inseria os moradores de rua no mercado de trabalho, apresentando uma perspectiva de intersetorialidade entre as políticas públicas, e possuía um viés positivo na valorização das atividades desenvolvidas pelos moradores de rua. Nesse sentido, a retirada do Núcleo de Catadores do Projeto foi, claramente, uma perda.

\footnotetext{
370 Referimo-nos nessa parte aos dois primeiros convênios celebrados com a Associação APOIO, ainda em
} 2008: Termo de Convênio 246/SMADS/2008 e Termo de Convênio 247/SMADS/2008. 
Contudo, nem todos os aspectos referentes ao Núcleo de Catadores apresentava estrutura adequada, sendo possível se apontar alguns problemas.

Primeiramente, o espaço reservado aos catadores somente recriava o próprio espaço da rua, em que os catadores são obrigados a dormir em seus carrinhos por questão de segurança. $^{371}$ Recriar essa imagem de insegurança dentro do Projeto se mostra desnecessária e, em certa medida, irrefletida. Ademais, não estavam solucionados também problemas como a falta de privacidade, pois o alojamento dos catadores não previa divisões para assegurar espaços de individualidade.

Todavia, essas pequenas críticas referem-se somente a aspectos pontuais, e não tiram a validade e a importância da inserção do Núcleo de Catadores no Projeto.

\subsubsection{Vinculação à saúde}

No que toca à vinculação a questões referentes à saúde, é necessário tecer duas ordens de comentários: uma sobre a criação de vagas específicas para pessoas convalescentes e outra sobre a implantação de duas unidades de saúde dentro do Projeto Boracea (AMA Boracea e UBS Boracea).

Ao se analisar os diversos convênios celebrados, pode-se observar que no que toca especificamente aos serviços de saúde, houve alteração quanto aos primeiros convênios.

Em um primeiro momento, entre os anos de 2003-2006, a Secretaria de Assistência tinha parcerias tanto com a Secretaria Municipal de Saúde, como com parceiros civis (Centro de Saúde Escola Dr. Alexandre Wranjac). Nessa época, não havia previsão específica no que toca à acolhida de pessoas convalescentes, ou mesmo a integração direta com a Saúde, através de unidades fixadas dentro, ou mesmo próximas, ao Projeto.

A partir do Termo de Convênio 246/SMADS/2008, houve o oferecimento especificamente de serviço de Acolhida Especial para pessoas, em período de convalescença, após alta hospitalar recebida da rede pública de saúde. A celebração desse convênio foi parcialmente responsável pela alteração do perfil dos usuários, pois a partir desse momento, o número de pessoas convalescentes usuárias do Projeto aumentou.

371 A segurança patrimonial ou mesmo física para aqueles que vivem na rua é uma questão recorrente na rua. Os moradores de rua que não se valem dos serviços de albergues muitas vezes são roubados ou furtados ao não vigiarem seus bens. Isso gera problemas graves, como a perda de seus instrumentos de trabalho, incluindo nesse contexto a carroça dos catadores, como também a totalidades de documentos e pertences pessoais. 
Ademais, buscou-se instalar a intersetorialidade entre Assistência Social e Saúde, com a criação, em 2008, de dois serviços de saúde dentro do Projeto, a saber, o AMA Boracea e a UBS Boracea.

A criação desses dois serviços se mostrou como um aspecto positivo. Sabe-se que a população em situação de rua, por sua vulnerabilidade, necessita de certos cuidados no que toca à saúde, que variam desde problemas devido à falta de higiene a doenças respiratórias (como a tuberculose), problemas com álcool e drogas e doenças sexualmente transmissíveis. Dessa forma, é necessário o estabelecimento de vínculos com o sistema de saúde.

Em abril de 2008, foi inaugurada uma unidade do programa de Assistência Médica Ambulatorial, a AMA Boracea, primeira unidade a funcionar junto a um albergue de atendimento a pessoas em situação de rua. A AMA Boracea foi criada para a prestação de serviços de saúde de pequenas urgências sem que houvesse necessidade de consulta, além de fornecer atendimento psiquiátrico. Contudo, também permitia o agendamento de consultas para clínica médica e pediátrica, além de contar com uma farmácia própria.

A implantação do AMA ocorreu por meio de parceria com a Instituição Irmãs Hospitaleiras. Em que pese a possibilidade de atendimento de moradores da região da Barra Funda, a AMA Boracea voltava-se para o atendimento em especial das pessoas em situação de rua e albergados, com acessibilidade para cadeiras de roda e chuveiro para higiene dos usuários. Ademais, a AMA Boracea contava com um diferencial, que era o atendimento psiquiátrico. ${ }^{372}$

Em novembro de 2008, foi inaugurada no Complexo Boracea uma Unidade Básica de Saúde ${ }^{373}$, também como resultado da parceria entre as Secretarias Municipais de Saúde e de Assistência e Desenvolvimento Social. A Instituição Irmãs Hospitaleiras do Sagrado Coração de Jesus também foi responsável pela implantação da unidade. A intenção da SMADS era facilitar o tratamento de saúde de pessoas em situação de rua, que

372 Prefeitura inaugura AMA que atende moradores em situação de rua. Diário Oficial da Cidade de São Paulo, de 4 de abril de 2008, p. I. Notícias

373 As Unidades Básicas de Saúde (UBS) são a porta de entrada preferencial do Sistema Único de Saúde (SUS). O objetivo desses postos é atender até $80 \%$ dos problemas de saúde da população, sem que haja a necessidade de encaminhamento para hospitais. Nas UBSs, os usuários do SUS podem realizar consultas médicas, curativos, tratamento odontológico, tomar vacinas e coletar exames laboratoriais. Além disso, há fornecimento de medicação básica e também encaminhamentos para especialidades. A expansão das Unidades Básicas de Saúde tem o objetivo de descentralizar o atendimento, dar acesso aos serviços de saúde e desafogar os hospitais. In: http://www.brasil.gov.br/saude/2011/09/usuarios-do-sus-seraoatendidos-em-unidades-proximas-a-seus-domicilios. 
tradicionalmente se mostra inibida, tendo em vista sua condição social, em buscar o sistema de saúde. Dessa forma, o atendimento a ser feito a essa população demandava uma atenção especial por parte dos profissionais de saúde, por sua particular condição de vulnerabilidade. ${ }^{374}$

Portanto, quanto à criação da AMA Boracea e da UBS Boracea, pode-se entender se tratar de aspectos positivos nas alterações ocorridas dentro do Projeto, por inserir os usuários em um contexto de cuidados à saúde. Demonstra que houve dedicação por parte da SMADS em prestar serviços básicos de saúde aos moradores em situação de rua, reforçando a tão necessária intersetorialidade entre os serviços voltados à população de rua.

\subsubsection{Projeto arquitetônico e infraestrutura}

Como já mencionado anteriormente, tanto a Lei ${ }^{\circ}$ 12.316/1997 quanto o Decreto $\mathrm{n}^{\circ} 40.232 / 2001$ preveem os padrões de qualidade que os serviços de abrigo e albergues devem seguir, esclarecendo que os alojamentos terão número máximo de até 100 (cem) pessoas por unidade conveniada e deverão fornecer condições de pernoite, higiene pessoal, lavagem e secagem de roupas, alimentação, guarda-volumes, trabalho sócio educativo e serviços de documentação. Preveem ainda o número máximo de 20 pessoas por cômodo, com espaços marcados por divisórias, garantindo a privacidade dos usuários. Por fim, determinam que as acomodações sejam arejadas, iluminadas e limpas. A legislação chega até a descrever a qualidade dos colchões a serem usados, e a necessidade de camas e beliches.

Pela análise do projeto original da Oficina Boracea, assim como pelos convênios celebrados, pode-se notar que em nenhum momento - com exceção ao Centro Acolhida Especial, com 80 vagas e o Centro de Acolhida para Idosos, com 100 vagas - respeitou-se o limite máximo de 100 pessoas por equipamento.

Espaços de acolhida com grande dimensão - e, por consequência, maior número de usuários - tendem a reforçar a situação de vulnerabilidade e exclusão por parte dos usuários, impedindo o espaço necessário à demonstração da singularidade de cada um, ${ }^{375}$

374 UBS Boracea atende população que vive na rua na região central. Diário Oficial da Cidade de São
Paulo, de 30 de janeiro de 2009 , p. I. Notícias.
375 LAVARELLO, Fernanda Bastos. Pessoas em situação de rua: análise psicossocial de uma intervenção no 
além de trazer dificuldades no que toca a uma forma de atendimento mais humanizada.

Em 2007, após visita realizada no Complexo Boracea, ainda durante o convênio com o Instituto Cirineu, Padre Julio Lancelotti, da Pastoral do Povo da Rua, argumentou que, por se tratar de um equipamento muito grande, não havia como manter tal espaço com dignidade, e que o Projeto aumentava a segregação dos usuários. ${ }^{376}$

Todavia, em que pese se tratar de um equipamento com dimensões acima daquelas recomendadas pela lei e pelo decreto municipais, o Complexo Boracea não é o único equipamento que se encontra nessa situação, sendo relativamente comum a existência de centros de acolhida com mais de 100 pessoas. ${ }^{377}$ Trata-se, efetivamente, de uma tendência dentro da rede conveniada.

Além do tamanho do Complexo, alguns aspectos do projeto arquitetônico original se mostraram "romantizados": a questão da utilização das redes e a construção de uma fogueira no pátio central, além de inadequadas nos termos da Lei de Atenção à População de Rua, mostravam-se perniciosas à saúde. Nem a Lei $n^{\circ} 12.316$, nem o Decreto $n^{\circ} 40.232$ preveem a utilização de redes. Pelo contrário, enfatizam a necessidade de utilização de camas, com colchões adequados, para promover o conforto aos usuários. É necessário ressaltar ainda que as pessoas em situação de rua tem um cotidiano muito desgastante, sendo comum a realização de atividades extenuantes fisicamente, principalmente no caso dos catadores de materiais recicláveis. Muitas pessoas ainda têm problemas de saúde ou são idosas, reforçando a inadequação da utilização de redes.

Algo semelhante pode ser dito em relação à fogueira central. Ela remonta a aspectos de vivência na rua, como forma de confraternização. Mas como espaço de encontro dentro de um serviço assistencial, é questionável sua implementação e utilização, até por motivos de segurança interna, dos usuários e dos funcionários.

A consulta à população usuário dos serviços a serem prestados no Complexo teria facilitado a implementação de formas mais utilitárias na prestação dos serviços, o que no caso do Boracea, não ocorreu. Utilizar a própria população em situação de rua e o relato de suas experiências como material em uma pesquisa acadêmica retira essas pessoas de uma posição de mero espectadores ou plateia de seus próprios destinos, e os inclui como

Projeto Oficina Boracea. (...) pp.63-64.

376 Oficina Boracea vira depósito de sem teto. Jornal da Tarde. 21/09/2007.

377 A título de exemplo, pode-se citar a Sociedade Beneficiente São Camilo (300 vagas), Centro de Acolhida Samaritano (150 vagas), Centro de Acolhida Portal do Futuro (222 vagas), Centro de Acolhida Estação Vivência (200 vagas), Centro de Acolhida São Camilo (200 vagas) e Centro de Acolhida Pedroso (260 vagas). 
participantes ativos na formação de uma análise coletiva, levando-se em conta que são eles os mais interessados em ver alguma mudança efetiva em suas situações presentes. ${ }^{378}$

Há modelos interessantes de elaboração aplicados no exterior, como o Stratchan House e Meeting Place. O Stratchan House é projeto voltado para o abrigamento de pessoas por períodos longos ou curtos, enquanto o Meeting Place permite o convívio dos usuários durante o período diurno. O diferencial desses dois modelos em relação aos tradicionais Centros de Acolhida e Centros de convivência é a possibilidade de intervenção por partes dos usuários, ou até mesmo de funcionários. ${ }^{379}$

O modelo do Street City também se apresenta como uma alternativa interessante, mais inclinada para soluções voltadas para a criação de programas habitacionais. A ideia é se utilizar de um galpão abandonado, no qual as pessoas passassem a morar até a construção de suas habitações permanentes. Seu diferencial em relação a outros programas é a abertura dada aos usuários para que contribuam para sua elaboração. ${ }^{380}$

Mais do que procurar soluções adotadas em outros países, o que se buscou apontar é a necessidade, em alguma medida, de participação dos usuários na elaboração de projetos e na condução da política a eles aplicadas.

\subsubsection{Cursos profissionalizantes e resgate da cidadania}

Um dos grandes diferenciais do Projeto original foi sua dedicação à capacitação e resgate da cidadania dos usuários, principalmente no que toca aos cursos de capacitação. Muitos usuários afirmaram que, mesmo após terem passado anos na rua ou mesmo por outros serviços de acolhimento, no Projeto Boracea tiveram nova chance de aprendizado, capacitação e contato com cultura, e vislumbravam a possibilidade de mudança de vida. ${ }^{381}$

No início do projeto, entre os anos de 2003 a 2006, havia uma infinidade de atividades oferecidas, envolvendo tanto aspectos socioeducativos como de lazer. Além disso, foram desenvolvidos programas voltados para a geração de renda: oficinas de

378 KERR, Daniel. "We know what the problem is": using oral history to develop a collaborative analysis of the homellessness from the bottom up. p. 30. In: The Oral History Review. Vol. 30, $\mathrm{n}^{\mathrm{o}} 1$ (Winter - Spring 2003). pp. 27-45.

379 ENDRIGUE, Taisa da Costa. Repensando o Projeto Boracea - Proposta de Abrigo para moradores de rua da Cidade de São Paulo. (...) pp.46-47.

380 BOSWORTH, Bill, YAMASHITA, Roberto. Apresentação dos trabalhos realizados em Toronto: Ação Governamental e Street city. In: ROSA, Cleisa Moreno Maffei (org.). População de rua: Brasil e Canadá. São Paulo: Hucitec, 1995. p.140-149.

381 SIMÕES, Janaína Machado. Projeto Oficina Boracea. p. 215-216. 
produção de objetos com materiais recicláveis, loja social, galpão de separação e pesagem de materiais recicláveis, venda de materiais recicláveis.

Uma das associações que realizava trabalhos profissionalizantes, a CEEP, chegou até a ser premiada com o Prêmio Betinho de Cidadania de 2004. ${ }^{382}$ Contudo, em que pese o reconhecimento do bom trabalho desenvolvido, o convênio com a CEEP não foi renovado, tendo sido em seguida substituído pelo convênio celebrado com o Instituto Lygia Jardim SASECOP. Nota-se que em um prazo relativamente curto, entre 2003 e 2006, houve descontinuidade de dois serviços, o que eventualmente gerou prejuízo aos seguimento dos programas desenvolvidos.

Com o convênio único celebrado em 2006, como Instituto Cirineu, havia a previsão de prestação do serviço de Núcleo de Inserção Produtiva, com 320 vagas, que representava, ao menos, uma oportunidade para capacitação dos usuários com o objetivo de reinseri-los socialmente e profissionalmente. A partir de 2008, com os convênios celebrados com a Associação APOIO, sequer havia a previsão dessa atividade voltada à profissionalização.

Em realidade, a partir de 2008/2009, nota-se o aumento maciço de vagas para acolhida dentro do Projeto, chegando a mais de 1000. Dessa forma, percebe-se a ênfase da SMADS em lançar editais voltados somente para acolhida, e não para capacitação profissional, indicando que o novo perfil do Boracea será somente a prestação de serviços voltados para a sobrevivência diária das pessoa em situação de rua.

Essa tendência que ocorreu dentro do Projeto Boracea também é comum ao perfil da rede conveniada de serviços, de forma geral, como já mencionado: ao se observar os número de 2008 a 2013, pode-se notar que enquanto o número de centros de acolhida e vagas aumentaram de 38, em 2008, para 50, em 2013, os serviços de Núcleo de Serviço e Convivência/Inserção Produtiva e Capacitação mantiveram os mesmos números entre 2008 e 2013: 11 .

A tendência da rede, portanto, é focar-se em serviços de perfil acomodativo, ou seja, serviços que voltam-se somente para as necessidades diárias de pernoite, alimentação e higiene.

\subsection{6. "Higienismo" e repressão}

382 VICTORIANO, Eliana Fernandes Loureiro. Projeto Oficina Boracea. (...) p.69. 
Por fim, pode-se observar também que antes mesmo do Projeto ser implantado, moradores do bairro da Barra Funda se dispuseram contra a ideia de projeto de um albergue para pessoas em situação na região, numa postura claramente expulsionista.

O incômodo por parte de moradores em bairros residenciais, quando se veem em face de equipamentos para população em situação de rua, não é algo incomum no contexto paulistano. Há um desconforto em se manter na presença constante de pessoas em situação de rua, e como consequência, se vê como alternativa a não aceitação ou até mesmo a expulsão dos moradores de rua de certos espaços.

Só a título de exemplificação, em 2011, moradores e comerciantes na região de Pinheiros fizeram um abaixo-assinado com 1.200 assinaturas e entregaram ao Ministério Público Estadual, pois se opunham à transferência de um albergue para uma área mais residencial, também localizada no mesmo bairro, afirmando que a mudança de alocação do albergue iria "provocar um impacto na região, prejudicando o comércio e a segurança da população”. O caso ganhou maior repercussão quando o Promotor de Habitação e Urbanismo de Capital julgou as atitudes do grupo de moradores como intolerantes, tendo inclusive enviado os nomes de seis síndicos que assinaram o abaixo-assinado para a Delegacia de Polícia Especializada em Crimes Raciais de Delitos de Intolerância (Decradi), para que se iniciasse uma investigação. ${ }^{383}$

No caso do Projeto Oficina Boracea, não foi diferente. Como já afirmando acima, foi criada uma associação dos moradores da região, visando impedir a instalação do projeto no local idealizado. Um dos moradores da região chegou até a dizer textualmente que “devemos resgatar a autoestima deles (moradores de rua), mas sem perder a nossa”"384.

Somente após alterações no projeto, como a mudança da entrada, que buscavam diminuir a circulação de moradores de rua, o projeto foi aceito pela comunidade.

A presença de uma base comunitária da Polícia Militar dentro do Projeto também se mostrou um tanto estranha. É de se questionar a função de uma base da Polícia Militar dentro do Projeto, para quê serviria e a quem protegeria.

\footnotetext{
383 Albergue para moradores de rua causa polêmica em bairro de SP. G1. São Paulo. 17/10/2011; Promotor vê nazismo em ação que quer remover albergue de Pinheiros. Estado de São Paulo. 13/10/2011.

384 SP vai atender catador e seu melhor amigo. Folha de São Paulo. 15/12/2002.
} 


\section{CONSIDERAÇÕES FINAIS}

O presente projeto buscou analisar a política pública voltada à população em situação de rua na cidade de São Paulo, procedendo-se ao estudo de caso de um complexo de serviços localizado na região central da capital: o Complexo Boracea.

No primeiro capítulo, foram traçados delineamentos gerais sobre a população em situação de rua, e sua visibilidade social. Nesse capítulo introdutório, também se discorreu sobre as formas pelas quais a população em situação de rua vem sendo auxiliada, indicando que além do auxílio prestado pela sociedade civil e por entidades privadas, algumas delas ligadas à igreja, surgiu há algumas décadas a percepção da necessidade de se formular políticas públicas por meio do Estado, com objetivo de prestação de serviços a essa população. Nesse contexto, situou-se o objetivo central do trabalho: a análise específica de um serviço público sócio assistencial voltado para a população em situação de rua na cidade de São Paulo.

No segundo capítulo, buscou-se analisar, de maneira breve, a alteração histórica da função do Estado, que se viu obrigado a intervir na sociedade e atuar sobre problemas sociais. Procurou-se também, ainda que de forma concisa, discutir a evolução da política social dentro da América Latina. Ao final do capítulo, passou-se à descrição das bases gerais da política social dentro do Brasil, discutindo-se, em seguida e de modo específico, as funções e atribuições da política assistencial no contexto nacional, assim como os marcos constitucionais e legais da assistência social no Brasil.

Pela descrição feita, pode-se perceber que, a partir da Constituição Federal de 1988, a Assistência Social se edifica como direito e não mais como favor ou doação, sendo inaugurada uma nova fase em termos de política social. Com a nova ordem constitucional, a política sócio assistencial passa a ter origem pública e surge como integrante do sistema da Seguridade Social.

Tendo por base a Constituição Federal, são editadas diversas normas que dão enfoque à descentralização da política sócio assistencial, pregando, ao mesmo tempo, a necessidade de articulação entre as três esferas de governo, de forma a integrar o sistema da Assistência Social de forma orgânica. Esse conjunto de normas buscou reforçar a necessidade de uma gestão pactuada entre governos federal, estadual e municipal, 
rejeitando ações fragmentadas, muito comuns no passado. Mediante novos instrumentos, buscou-se também uniformizar, aprimorar e ampliar os serviços da assistência social em todo o país, procurando conjugar as atividades da assistência às demais políticas públicas.

O novo arcabouço legal criado também vai no sentido de inserir a participação da sociedade civil dentro do plano de execução e fiscalização das políticas sociais. Dessa forma, ao mesmo tempo em que entidades civis são convidadas a participar do controle e gestão das políticas assistenciais, também serão responsáveis pela execução e pela prestação final do serviços sócio assistenciais.

No terceiro capítulo, procedeu-se à análise da população em situação de rua como uma questão social nascida somente em tempos recentes, surgindo, daí, a necessidade de atuação do Estado, que deverá intervir por meio de políticas públicas específicas. Contudo, para que possa desenvolver políticas públicas adequadas, o Estado deverá conhecer o perfil das pessoas em situação de rua, motivo pelo qual se passou à análise das principais características dessas pessoas, concluindo-se se tratar de um grupo marcado por uma série de vulnerabilidades. Após, iniciou-se uma exposição de uma tipologia das formas pelas quais a sociedade responde, em seu cotidiano, à presença dos moradores de rua. Ao final deste capítulo, foram trazidos dados sobre os serviços públicos voltados para a população de rua, e um breve panorama da evolução dos serviços prestados.

A partir da pesquisa realizada, pode-se observar que a cidade de São Paulo, ao longo das últimas décadas, vem acumulado experiências que possibilitaram a estruturação de um política de atendimento à população em situação de rua. A associação do conhecimento obtido por meio de entidades civis, em conjunto com as iniciativas do poder público, deram origem à atual rede de serviços voltada a essa população, que cresce em serviços e vagas e vem diversificando os programas desenvolvidos, adquirindo novas funções e procedimentos. Sob a coordenação da Secretaria Municipal de Desenvolvimento e Assistência Social, o arcabouço jurídico criado permitiu o desenvolvimento de diversos serviços, com a participação de muitas associações civis envolvidas, intercalando saberes e se conectando em uma rede com consistência razoável.

Processo iniciado na década de 90, através das primeiras casas de convivência e albergues, a rede assistencial voltada à população em situação de rua é referência no país, e o conjunto de práticas, bem ou mal sucedidas, se tornou um modelo. Nota-se também que, 
ao mesmo tempo em que essa rede conveniada vem crescendo e evoluindo, a quantidade de pessoas em situação de rua também cresce.

A análise das políticas públicas voltadas para a população de rua mostrou também um novo arranjo na forma de prestação de serviços públicos: em que pese haver serviços que são prestados diretamente pelo Estado, em São Paulo, a maior parte desses são prestados como decorrências de convênios ou parcerias, celebrados com entidades sem fins lucrativos.

No quinto capítulo, realizou-se um estudo de caso, analisando a estrutura e evolução de um dos serviços da rede conveniada à SMADS/Prefeitura de São Paulo.

O estudo de caso realizado indicou que o Projeto Oficina Boracea, iniciado como um projeto modelo para a recuperação da vida de moradores de rua, acabou se tornando um albergue comum, ou seja, voltado somente para a satisfação de necessidades cotidianas, como pernoite, alimentação e higiene. Para se utilizar da tipologia desenvolvida por Snow e Anderson, a rede de serviços criada no Projeto Boracea era de perfil restaurativo, mas em grande parte, devido à ampla quantidade de mudanças quanto ao projeto original, acabou se tornando de perfil acodomodativo.

O projeto Oficina Boracea foi inaugurado como sendo o maior equipamento dentro do Programa Acolher: Reconstruindo Vidas. O público-alvo do Boracea eram as pessoas em situação de rua, em especial os catadores de materiais recicláveis, sendo o foco do projeto o resgate da autonomia, a reinserção social e a cultura de direitos. Para tanto, eram previstos diversos serviços, dentre eles atividades culturais, esportivas, assim como cursos de capacitação profissional. Diversas associações, através de convênios celebrados com a SMADS, participavam do Projeto, e a gestão era mista, realizada conjuntamente pelas entidades civis e pelo poder público.

Com a saída da Prefeita Marta Suplicy e da Secretaria Aldaíza Sposati, algumas alterações começaram a se sentir e o projeto original passou a ser completamente modificado. $\mathrm{O}$ modelo inovador - ao menos no que toca ao arranjo institucional do serviço - terminou por se tornar uma política de governo, e não de Estado. Pode-se notar ainda a grande falta de continuidade tanto na prestação de serviços específicos, como nos convênios celebrados com certas entidades. 
Primeiramente, alguns convênios voltados para capacitação profissional e o convívio não foram renovados, o que gerou tanto uma perda em termos de atividades voltadas ao desenvolvimento da autonomia - tendo em vista a existência de projetos de economia solidária e capacitação profissional - como também ocasionou uma falta de continuidade no serviço prestado. O núcleo de atendimentos aos catadores de materiais recicláveis, tão importante no início do Projeto e por ser voltado à autonomia, também foi retirado do local.

A partir de 2006, o Projeto passou então a ser gerido sem a participação direta do poder público, que somente fazia supervisão, e em vez da prestação de serviços por diversas entidades, a SMADS decidiu centralizar a responsabilidade pelo Projeto Boracea em somente uma entidade: o Instituto Cirineu. Contudo, essa organização, após um ano de duração, teve seu convênio rescindindo. Na época, a Secretaria de Assistência Social informou que o número de denúncias contra o Projeto havia aumentado muito nos últimos tempos e que a entidade que prestava os serviços seria substituída pela Associação APOIO, o que efetivamente ocorreu.

A partir do final de 2008, aumentou-se a capacidade do Complexo Boracea, com a celebração de novos convênios voltados principalmente para a acolhida - como convênios específicos voltados para idosos e pessoas convalescentes - e para o atendimento de necessidades diárias, como alimentação, banho e lavagem de roupa - como o convênio de atenção urbana e espaço de convivência. Desde sua criação, o Projeto Boracea já acolhia mais pessoas que o recomendado pela Lei de Atenção à População de Rua (lei municipal 12.316/1997), variando entre 400 a 600 pessoas. Todavia, atualmente, o espaço expandiu em muito a quantidade de vagas voltadas para a acolhida, contando hoje com mais de mil vagas. Infelizmente, o Complexo Boracea não é o único serviço voltado à população de rua com capacidade para mais de 100 pessoas, o que revela uma tendência da rede de serviços a possuir espaços com grandes dimensões, sendo reiterado o descumprimento à Lei 12.316 e as diretivas lá previstas.

Ademais, os novos convênios celebrados - e que ainda se mantêm vigentes somente reiteraram o perfil acomodativo da nova configuração do Complexo Boracea, sem inserção específica no que toca à capacitação profissional. Ao mesmo tempo, houve ao menos a iniciativa em garantir serviços de saúde, com a criação do AMA Boracea e da UBS Boracea. 
Em realidade, a falta de articulação entre as diversas políticas sociais é uma tendência no que toca aos serviços voltados à população de rua, que atuam, quase que exclusivamente, em serviços sócio assistenciais como atendimentos, obtenção de documentos e acolhida. Há pouca articulação externa entre a assistência e as demais políticas sociais que, no caso da população em situação de rua, representam, na grande maioria das vezes, a única saída para uma vida autônoma.

Percebe-se, portanto que, em termos institucionais, ainda não houve a criação de protocolos e estratégias entre as várias secretarias, com o objetivo de alcançar uma política social unificada. ${ }^{385}$ Esses aspectos precisarão ser revistos de forma a buscar a garantia de uma maior efetividade dos direitos sociais dessa população.

Ao mesmo tempo, notou-se que o arcabouço jurídico desenvolvido, tanto em âmbito nacional como municipal, associados à criação de instrumentos e serviços voltados à população em situação de rua no âmbito da assistência social, representou um ganho em termos de construção de políticas públicas para essa população. A partir da Lei de Atenção da População de Rua, editada em 1997, e com as posteriores regulamentações dela decorrentes, o sistema jurídico tem colaborado, ao menos, para a inserção dessa temática na arena do direito público, permitindo a discussão, questionamento e aprimoramento de práticas voltadas à garantia de direitos da população em situação de rua.

Dessa forma, quando comparado ao cenário anterior, marcado pela atuação primordialmente voluntarista de instituições religiosas, sem qualquer compromisso com continuidade do serviços prestados, ou mesmo vinculação com a noção de direitos, a formulação jurídica e a institucionalização por meio do direito público inaugurou um novo patamar de atuação, com normas que instituem deveres e responsabilidades, permitindo o controle tanto por parte do Estado como pela sociedade civil, sempre embasado pela noção de garantia de direitos e promoção da cidadania.

385 RAMOS, Ana Márcia Fornaziero. Potencialidades e desafios nas parcerias entre a secretaria municipal de assistência Social e desenvolvimento social e as entidades sociais na cidade de São Paulo: um estudo dos serviços voltados para a população em situação de rua. (...) p. 172. 


\section{BIBLIOGRAFIA}

\section{Livros e artigos}

ALTEMEYER JUNIOR, Fernando. Compaixão em processos sociais e mudanças institucionais: o caso do vicariato episcopal do povo da rua em São Paulo. Doutorado em Ciências Sociais. Pontifícia Universidade Católica de São Paulo. São Paulo. Ano de Obtenção: 2006

AMARAL, Denise Perroud. A Rede de Atenção à População em Situação de Rua: possibilidades de interferência na definição e concretização de uma política pública na cidade de São Paulo. Mestrado em Serviço Social. Pontifícia Universidade Católica de São Paulo. Ano de obtenção: 2010.

BARROS, Joana da Silva. Moradores de rua - Pobreza e Trabalho: interrogações sobre a exceção e a experiência política brasileira. Mestrado, Programa de Pós-Graduação em Sociologia, do Departamento de Sociologia da Faculdade de Filosofia, Letras e Ciências Humanas, USP, 2004.

BOSWORTH, Bill, YAMASHITA, Roberto. Apresentação dos trabalhos realizados em Toronot: Ação Governamental e Street city. In: ROSA, Cleisa Moreno Maffei (org.). População de rua: Brasil e Canadá. São Paulo: Hucitec, 1995. p.140-149.

CALDEIRA, Teresa Pires do Rio. Cidade de muros: crime, segregação e cidadania em São Paulo. São Paulo: Editora 34/Edusp, 2000.

CAMARGO, Cândido Procópio Ferreira de [et al]. São Paulo 1975. Crescimento e pobreza. 13ª edição. Edições Loyola, São Paulo. 1982.

CARVALHO, José Murilo de. Os bestializados: O Rio de Janeiro e a república que não foi. São Paulo: Companhia das Letras, 1987.

CARVALHO, Maria do Carmo Brant. A política da Assistência Social: novos desafios. Políticas Públicas em Debate. Ciclo de Seminários. Fundap em 30 de junho de 2009.

A Seguridade na travessia do Estado assistencial brasileiro. In: SPOSATI, Aldaíza. CARVALHO, Maria do Carmo Brant; FLEURY, Sônia Maria Teixeira. Os direitos dos desassistidos sociais. $7^{a}$ edição. São Paulo: Cortez, 2012. pp. 143-164.

CASTELVECCHI, G. (org.). Somos um povo que quer viver. São Paulo: Edições Paulinas, 1982.

CASTRO, Jorge Abrahão de. RIBEIRO, José Aparecido. CAMPOS, André Gambier. MATIJASCIC, Milko. A CF/88 e as políticas sociais brasileiras. In: A Constituição brasileira de 1988 revisitada: recuperação histórica e desafios atuais das políticas públicas nas áreas econômica e social. Org.: CARDOSO JR., José Celso. Brasília: Ipea, 2009. v. 1. pp. 55-122. 
CENTRO DE ESTUDOS RURAIS E URBANOS (CERU). Trajetória de vida da população atendida nos serviços de acolhimento para adultos em situação de rua município de São Paulo. 2010.

COSTA, Daniel De Lucca Reis. Rua em movimento: Experiências urbanas e jogos sociais em torno da população em situação de rua. Dissertação de Mestrado. Faculdade de Filosofia, Letras e Ciências Humanas. Departamento de Antropologia. Ano de obtenção: 2007.

DESLAURIERS, Jean-Pierre; KÉRISIT, Michèle. O delineamento da pesquisa qualitativa. pp. 127- 153. In: POUPART, Jean; DESLAURIERS, Jean-Pierre; GROULX, Lionel-Henri; LAPERRIÈRE, Anne; MAYER, Robert; PIRES, Álvaro. A pesquisa qualitativa: enfoques epistemológicos e metodológicos. Tradução de Ana Cristina Nasser. Petrópolis: Vozes, 2008.

DOMINGUES JÚNIOR, Paulo Lourenço. Cooperativa e construção da cidadania da população de rua. São Paulo: Edições Loyola/Editora Universitária Leopoldianum, 2003.

DRAIBE, Sonia Miriam. As políticas de combate à pobreza na América Latina. In: São Paulo em Perspectiva. Volume 4 (2). pp. 18/24. 1990.

desenvolvimentista e a agenda recente de reformas. Caderno de pesquisa n. 32. Núcleo de Pesquisa de Políticas Públicas. Universidade Estadual de Campinas. 1998.

ENDRIGUE, Taisa da Costa. Repensando o Projeto Boracea - Proposta de Abrigo para moradores de rua da Cidade de São Paulo. Trabalho Final de Graduação, Faculdade de Arquitetura e Urbanismo, USP, 2002.

ESCOREL, Sarah. Vidas ao Léu - Trajetórias de exclusão social. Rio de Janeiro: Editora Fiocruz, 1999.

ESPING-ANDERSEN, Gosta. Welfare States in transition: national adaptations in global economies. UNRISD. 1996.

FAGNANI, Eduardo. Direitos Sociais no fio da navalha. In: VAZ, Flavio Tonelli; MUSSE, Juliano Sander; SANTOS, Rodolfo Fonseca (organizadores). 20 Anos de Constituição Cidadã. Avaliação e Desafio da Seguridade Social. Brasília, ANFIP, 2008. pp. 23-44.

FERRO, Maria Carolina Tiraboschi. Desafío de la participación social: alcances y límites de la construcción de la Polítca Nacional para la Población en Situación de Calle en Brasil. Dissertação de Mestrado em Ciência Política e Sociológica. Área de Estudos Políticos. Facultad Latinoamericana de Ciencias Sociales. Ano de obtenção: 2012.

FESPSP - Núcleo de Pesquisas em Ciência Sociais. Prefeitura do Município de São Paulo. Secretaria Municipal de Assistência e Desenvolvimento Social. Censo da população de rua na cidade de São Paulo. Principais Resultados. (2011); 
de rua de São Paulo. (2011);

Caracterização socioeconômica da população em situação

. Censo e Caracterização Sócio econômica da população em situação de rua na municipalidade de São Paulo. (2011).

FLEURY, Sônia. O Estado sem cidadãos. Seguridade Social na América Latina. Editora Fiocruz: Rio de Janeiro, 1994.

FRAGELLA, Simone Miazara. Corpos urbanos errantes: uma etnografia da corporalidade de moradores de rua em São Paulo. Annablume, Fapespe, 2009.

FUNDAÇÃO INSTITUIÇÃO DE PESQUISAS ECONÔMICAS - FIPE: Principais resultados do censo da população em situação de rua de São Paulo, 2009.

FUNDAÇÃO INSTITUIÇÃO DE PESQUISAS ECONÔMICAS - FIPE: Principais Resultados do Perfil Socioeconômico da População de Moradores de Rua da Área Central da Cidade de São Paulo

FUNDAÇÃO INSTITUIÇÃO DE PESQUISAS ECONÔMICAS - FIPE: Trajetória de Vida da População Atendida nos Serviços de Acolhimento para Adultos em Situação de Rua - Município de São Paulo

GIORGETTI, Camila. Moradores de rua: uma questão social? São Paulo: Fapesp, Educ, 2010 .

Poder e contrapoder: imprensa e morador de rua em São Paulo e Paris. São Paulo: Fapesp/EDUC, 2007.

HUBER, Evelyn. Options for social policy in Latin America: Neoliberal versus democratic models. In: ESPING-ANDERSEN, Gosta. Welfare States in transition: national adaptations in global economies. UNRISD. 1996.

IANNI, Octavio. A questão social. São Paulo em Perspectiva. 5 (1): 2-10, janeiro-março de 1991.

JACCOUD, Luciana. Entre a pobreza e a cidadania: a política pública de assistência social no pós-88. In: VAZ, Flavio Tonelli; MUSSE, Juliano Sander; SANTOS, Rodolfo Fonseca (organizadores). 20 Anos de Constituição Cidadã. Avaliação e Desafio da Seguridade Social. Brasília, ANFIP, 2008. pp. 255-265.

KERR, Daniel. "We know what the problem is": using oral history to develop a collaborative analysis of the homellessness from the bottom up. In: The Oral History Review. Vol. 30, $\mathrm{n}^{\circ} 1$ (Winter - Spring 2003). pp. 27-45.

LAVARELLO, Fernanda Bastos. Pessoas em situação de rua : analise psicossocial de uma intervenção no Projeto Oficina Boracea. Tese de Conclusão de Curso. Pontifícia Universidade Católica. 2004.

LAVINA, Lenas. Inclusão e progressividade: os desafios da Seguridade Social Brasileira. 
In: VAZ, Flavio Tonelli; MUSSE, Juliano Sander; SANTOS, Rodolfo Fonseca (organizadores). 20 Anos de Constituição Cidadã. Avaliação e Desafio da Seguridade Social. Brasília, ANFIP, 2008. pp. 89-96.

LEFEVRE, Henri. O direito à cidade. Tradução Rubens Eduardo Frias. São Paulo: Centauro, 2001.

MACHADO, Igor Rolemberg Gois. Violações de direitos humanos e cidadania categorizada: estudo de caso a partir da população em situação de rua do centro de São Paulo. Tese de Conclusão de Curso. Faculdade de Direito da Universidade de São Paulo. 2011.

MARTINS, Sérgio Pinto. Direito da Seguridade Social. 32ª edição. São Paulo: Atlas, 2012.

MATIJASCIC, Milko. DRAIBE, Sônia Miriam. The Market orientation of social security. Caderno de pesquisa n. 44. Núcleo de Pesquisa de Políticas Públicas. Universidade Estadual de Campinas. 1998.

MESA-LAGO, Carmelo. Models of Development, Social Policy and Reform in Latin America. In: MKANDAWIRE, Thandika (editor). Social Policy in a Development Context. United Nations Research Institute for Social Development. Palgrave Macmillan: 2005. pp. 175-222.

NERI, Marcelo Cortês (coord.). De volta ao país do futuro: Projeções, crise europeia e nova classe média. FGV/CPS. Rio de Janeiro, 2012.

OLIVEIRA, Cláudia Hochmann; PINTO, Maria Meira. Política de Assistência Social e Cidadania no Brasil hoje: alguns elementos para discussão. In: Katálisys. V. 8, n. 1, janeiro/junho de 2005. Florianópolis. Pp.46-58.

PEREIRA, Potyara A.P., Política Social: Temas \& questões. São Paulo: Editora Cortez, 2011.

PESARO, Floriano. O Futuro no presente. Por uma São Paulo mais humana e participativa. Editora Gente. São Paulo, 2008.

POCHMANN, Marcio. Proteção Social na Periferia do Capitalismo. Considerações sobre o Brasil. São Paulo em perspectiva. 18 (2). 2004, p. 3-16.

POLÍTICA NACIONAL PARA INCLUSÃO DE POPULAÇÃO EM SITUAÇÃO DE RUA. Maio de 2008. Governo Federal. Disponível em: http://www.recife.pe.gov.br/noticias/arquivos/2297.pdf. Acesso em 19/04/2012.

PONTIFÍCIA UNIVERSIDADE CATÓLICA DE SÃO PAULO. INSTITUTO DE ESTUDOS ESPECIAIS. Cadernos 2. 2004.

RAICHELIS, Raquel. Proteção Social e Trabalho do Assistente Social: tendências e disputas na crise mundial. Serviço Social e Sociedade. São Paulo, nº 116, out/dez de 2013, Pp. 609-635. 
Relatório sobre a situação social do país. Brasil 1985, volume I. Núcleo de Estudos em Políticas Públicas - Instituto de Economia da Unicamp.

RONCADA, Maria José. Inquérito entre migrantes atendidos pela central de triagem e encaminhamento, na capital do Estado de São Paulo, Brasil. I. Aspectos demográficos. Revista de Saúde Pública, São Paulo. N. 9, pp. 303-312. São Paulo.

ROJAS COUTO, Berenice. O Direito Social e a Assistência Social na Sociedade Brasileira: Uma equação possível? 4ª edição. São Paulo: Editora Cortez. 2010.

ROJAS COUTO, Berenice; YASBEK, Maria Carmelita; RAICHELIS, Raquel. A política Nacional de Assistência Social e o SUAS: apresentando e problematizando fundamentos e conceitos. In: ROJAS COUTO, Berenice; YASBEK, Maria Carmelita; SILVA E SILVA, Maria Ozanira; RAICHELIS, Raquel. O Sistema Único de Assistência Social: uma realidade em movimento. $3^{a}$ edição. São Paulo: Editora Cortez. 2012. Pp.54-113.

ROSA, Cleisa Moreno Maffei (org.). População de rua: Brasil e Canadá. São Paulo: Hucitec, 1995.

.Vidas de rua. São Paulo: Hucitec: Associação Rede Rua:

2005

SILVA, Maria Lucia Lopes da. Mudanças recentes no mundo do trabalho e o fenômeno população de rua no Brasil 1995-2005. Tese de mestrado. 2006. Universidade de Brasília.

SILVA E SILVA, Maria Ozanira; YASBEK, Maria Carmelita; DI GIOVANNI, Geraldo. A Política Social Brasileira no século XXI: a prevalência de programas de transferência de renda. 6a edição. São Paulo. Editora Cortez, 2012.

SIMÕES, Janaína Machado. Projeto Oficina Boracea. pp. 205-216. In: TEIXEIRA, Marco Antônio Carvalho; GODOY, Melissa; COELHO, Carla. 20 Experiências de Gestão Pública e Cidadania. São Paulo: Programa Gestão Pública e Cidadania. 2004.

SIMÕES JUNIOR. José Geraldo. Moradores de Rua. São Paulo: Pólis, 1992.

SINGER, André. Raízes sociais e ideológicas do Lulismo. Novos Estudos, n. 85, novembro de 2009, pp. 82-102.

SNOW, David A. \& ANDERSON, Leon. Down on their luck: a study on homeless street people. University of California Press. 1993.

SOUZA, Luiz Alberto Gómez. A Igreja Católica e a Questão Social. São Paulo em Perspectiva. Volume 11, número 4, 1997. P. 76-81.

SPOSATI, Aldaíza. A assistência social e a trivialização dos padrões de reprodução social. In: SPOSATI, Aldaíza. CARVALHO, Maria do Carmo Brant; FLEURY, Sônia Maria Teixeira. Os direitos dos desassistidos sociais. $7^{a}$ edição. São Paulo: Cortez, 2012. pp. 1343. 
elementos para discussão. Seminário Política de Assistência Social: novos Desafio. Fundap em 30 de junho de 2009. Políticas Públicas em debate. Ciclo de Seminários.

Tendências latino-americanas da política social pública do século 21. In: Revista Katálisis. Florianópolis. Volume 14, n. 1, pp. 104-115.

STOFELLS, Marie-Ghislaine. Os mendigos na cidade de São Paulo. Rio de Janeiro: Paz e Terra, 1977.

TELLES, Vera da Silva. No fio da navalha: entre carências e direitos. Notas a propósito dos programas de renda mínima no Brasil. In: Programas de renda mínima no Brasil: impactos e potencialidades. São Paulo: Pólis, 1998. P.30.

VARANDA, Walter. Descartáveis urbanos: discutindo a complexidade da população em situação de rua e o desafio para as políticas de saúde. Revista Saúde e Sociedade. V. 1. P. 56-69. Jan-abr 2004. p.61

VIEIRA, Maria Antonieta da Costa, BEZERRA, Eneida Maria Ramos \& ROSA, Cleisa Moreno Maffei. População de rua: quem é, como vive e como é vista. São Paulo: Hucitec, 1992.

VICTORIANO, Eliana Fernandes Loureiro. Projeto Oficina Boracea. Trabalho de Conclusão de Curso em Pós Graduação em Gestão Pública. Universidade Bandeirante de São Paulo. Ano de obtenção: 2008.

WERNECK VIANNA, Maria Lúcia Teixeira. Seguridade Social: um conceito e uma prática da civilização (ainda) moderna. In: VAZ, Flavio Tonelli; MUSSE, Juliano Sander; SANTOS, Rodolfo Fonseca (organizadores). 20 Anos de Constituição Cidadã. Avaliação e Desafio da Seguridade Social. Brasília, ANFIP, 2008. pp. 97-102.

YASBEK, Maria Carmelita. Assistência Social na cidade de São Paulo: a (difícil) construção do direito. Observatório dos Direitos dos Cidadãos. Instituto Pólis/PUC-SP. Março de 2014.

Paulo: Cortez, 2009.

Classes subalternas e assistência social. $7^{\mathrm{a}}$ Edição. São 


\section{Legislação, Publicações Oficiais}

BRASIL. Decreto-Lei n ${ }^{\text {3 } 3.688, ~ d e ~} 3$ de Outubro de 1941.

BRASIL. Decreto Presidencial 7.053, de 23 de dezembro de 2009.

BRASIL. Lei 8.742, de 7 de Dezembro de 1993 (Lei Orgânica da Assistência Social), redação dada pela lei 12.345 de 2011.

BRASIL. Resolução n. 109, de 11 de Novembro de 2009, do Conselho Nacional de Assistência Social. Aprova a tipificação nacional de serviços socioassistenciais.

BRASIL, Ministério do Desenvolvimento Social e Combate à Fome. Rua: aprendendo a contar - Pesquisa Nacional sobre População em Situação de Rua. Brasília: SAGI, 2009.

SÃO PAULO (município) Lei 12.316, de 16 de abril de 1997. Institui a Política Municipal de Inclusão da População de Rua.

SÃO PAULO (município). Lei 13.153, de 22 de junho de 2001. Dispõe sobre a política pública de atenções de assistência social, sem fins lucrativos, operada através de convênios no âmbito do Município de São Paulo.

SÃO PAULO (município). Decreto 40.232, de 2 de Janeiro de 2001. Regulamenta a Lei Municipal 12.316 (Política Nacional de Inclusão da População de Rua).

SÃO PAULO (município). Decreto $\mathrm{n}^{\circ}$ 43.698, de 2 de setembro de 2003. Regulamenta a Lei ${ }^{\circ} 13.153$, de 22 de junho de 2001, que dispõe sobre a política pública de atenções da assistência social, sem fins lucrativos, operada através de convênios no âmbito do Município de São Paulo.

SÃO PAULO (município). Prefeitura de São Paulo (Assistência Social). Portaria 46/2010/SMADS. Dispõe sobre a tipificação da rede socioassistencial do município de São Paulo e a regulação de parceria operada por meio de convênios.

SÃO PAULO (município). Prefeitura de São Paulo (Assistência Social). Portaria 47/2010/SMADS. Dispõe sobre a referência de custos dos serviços da rede socioassistencial operada por meio de convênios.

SÃO PAULO (município). Prefeitura de São Paulo. Regimento interno do conselho de monitoramento de políticas públicas para população em situação de rua.

SÃO PAULO (município). Prefeitura de São Paulo. Decreto $n^{\circ} .43 .277$, de 29 de maio de 2003, Instituiu o Conselho de Monitoramento de políticas públicas para população em situação de rua.

SÃO PAULO (município). Prefeitura de São Paulo. Decreto n ${ }^{\circ} 53.795$, de 25 de março de 2013. Institui o Comitê Intersetorial Da Política Municipal para a População em Situação de Rua - Comitê Poprua. 
ASSISTÊNCIA SOCIAL. Planilha de Custos. Centro de Acolhida 24 horas.

SÃO PAULO (município). SECRETARIA MUNICIPAL DE DESENVOLVIMENTO E ASSISTÊNCIA SOCIAL. Planilha de Custos. Centro de Acolhida 16 horas.

SÃO PAULO (município). SECRETARIA MUNICIPAL DE DESENVOLVIMENTO E ASSISTÊNCIA SOCIAL. Planilha de Custos. Centro de Acolhida Especial para Mulheres.

SÃO PAULO (município). SECRETARIA MUNICIPAL DE DESENVOLVIMENTO E ASSISTÊNCIA SOCIAL. Planilha de Custos. Núcleo de Convivência para População em Situação de Rua.

SÃO PAULO (município). DIÁRIO OFICIAL DA CIDADE DE SÃO PAULO.

SÃO PAULO (município). Prefeitura do Município de São Paulo. Secretaria Municipal de Assistência e Desenvolvimento Social. Núcleo de Pesquisas em Ciência Sociais - FESPSP. Censo da população de rua na cidade de São Paulo. Principais Resultados (2011).

SÃO PAULO (município). Documento Projeto Acolher: Reconstruindo Vidas. Prefeitura Municipal de São Paulo. Secretaria Municipal de Assistência Social. Gabinete da Secretária da Assistência Social.

SÃO PAULO (município). Folder “Acolher: Reconstruindo Vidas". Secretaria Municipal de Assistência Social. Prefeitura de São Paulo. 2002.

SÃO PAULO (município). Folder "Projeto.Oficina.Boracea". Secretaria Municipal da Assistência Social. Prefeitura de São Paulo. 


\section{Artigos de Jornais, Revistas e Periódicos}

Jornal da Tarde, 21 de setembro de 2007.

Estado de São Paulo, de 13 de outubro de 2011.

Estado de São Paulo, de 4 de fevereiro de 2010.

Folha de São Paulo, de 15 de dezembro de 2002.

Folha de São Paulo, de 05 de outubro de 2005.

G1, de 17 de outubro de 2011.

REDE BRASIL ATUAL. Moradores de Rua cobram políticas de habitação definitiva. 27/05/2009.

REDE BRASIL ATUAL. Com frente fria, São Paulo intensifica ações para pessoas em situação de rua. (acesso em 10/11/2013)

Jornal do Bom Retiro. Mês de Junho/2002

O Trecheiro, Mês de Maio de 2002.

O Trecheiro. Mês de Novembro de 2007.

O Trecheiro, Meses de Fevereiro, Maio, Julho de 2009.

O Trecheiro, Mês Setembro/Outubro de 2010.

O Trecheiro, Meses de Agosto, Setembro, Outubro, Novembro/Dezembro de 2011.

O Trecheiro, Fevereiro/Março, Abril, Novembro/Dezembro de 2012.

Prefeitura assina termo de adesão à Política Nacional para a População em Situação de Rua. http://www.prefeitura.sp.gov.br/cidade/secretarias/comunicacao/noticias/?p=148874

Prefeito inaugura $1^{\circ}$ Centro de Referência Especializado para População em Situação de Rua.

http://www.prefeitura.sp.gov.br/cidade/secretarias/subprefeituras/se/noticias/?p=15572.

Política Nacional para a população em situação de rua será implantada na cidade. http://www.prefeitura.sp.gov.br/cidade/secretarias/comunicacao/noticias/?p=148981

Com nova frente fria, Prefeitura intensifica ações para pessoas em situação de rua. http://www.prefeitura.sp.gov.br/cidade/secretarias/comunicacao/noticias/? $p=154504$

Pesquisas identificam o perfil de moradores de rua de SP. http://www.fipe.org.br/web/index.asp?c=37\&aspx=/web/home/noticia.aspx. 
Oficina.Boracea, o caminho de volta para casa. Diário Oficial do Município, de 30 de abril de 2005, p. II. Notícias

Secretaria vai expandir rede de proteção social à população de rua. Diário Oficial da Cidade de São Paulo, 30 de abril de 2005, p. II

Casas de portas aberta. O que a cidade oferece a quem quer deixar as ruas. Diário Oficial da Cidade de São Paulo, 23 de agosto de 2005, p. I.

Novos albergues terão atendimento personalizado e regras flexíveis. Diário Oficial do Município, de 6 de outubro de 2005, p. II. Notícias

O difícil resgate dos sonhos. Diário Oficial do Município, de 20 de agosto de 2006, pg. III. Notícias.

UBS Boracea atende população que vive na rua na região central. Diário Oficial da Cidade de São Paulo, de 30 de janeiro de 2009, p. I. Notícias

Espaço de Convivência Jardim da Vida completa um ano, com 71 mil atendimentos. Diário Oficial Cidade de São Paulo, de 3 de agosto de 2010.

Usuários do SUS serão atendidos em unidades próximas a seus domicílios. http://www.brasil.gov.br/saude/2011/09/usuarios-do-sus-serao-atendidos-em-unidadesproximas-a-seus-domicilios.

\section{Sites acessados:}

http://www.redebrasilatual.com.br (acesso em 10/11/2013)

http://www.senaposirua.ufscar.br/anais-do-seminario-1 (acesso em 15/02/2014)

http://acaoeticaecidadaniaong.blogspot.com.br/ (acesso em 16/02/2014)

http://www.asapam.org.br/Lygia Jardim/ (acesso em 16/02/2014)

http://www.brasil.gov.br/ (acesso em 16/02/2014)

http://www.rederua.org.br/rederua/ (acesso 23/02/2014)

http://www.aeb-brasil.org.br/ (acesso em 23/02/2014)

http://www.metodista.br (acesso em 23/02/2014)

http://ceep.org.br/ (acesso em 28/02/2014)

http://ccasaojose.org.br/ (acesso em 28/02/2014)

http://www.gaspargarcia.org.br/ (acesso em: 12/03/2014)

\section{Relatórios}

Ministério do Desenvolvimento Social e Combate à Fome. Relatório do I Encontro Nacional sobre População em Situação de Rua. Brasília, DF, 2006.

CEPAL/ONU. Panorama Social da América Latina. Documento Informativo. 2013. Comissão Econômica para a América Latina e Caribe/Organização das Nações Unidas. 